\title{
Non-Core Business? \\ An Examination of University Art Galleries in Aotearoa New Zealand
}

\author{
by \\ Penelope Baines
}

A thesis submitted to Victoria University of Wellington in partial fulfilment of the requirements for the degree of Master in Museum and Heritage Studies

Victoria University of Wellington 2015 


\begin{abstract}
University art galleries are the most common form of campus museum in New Zealand and are increasingly viewed as alternative and innovative interdisciplinary teaching tools. Much of the literature concerning university art galleries discusses the potential of these organisations to act as forums, laboratories and portals for the presentation of diverse ideas within institutions of higher education. Yet these organisations are often overlooked by their parent organisation and considered superfluous to the university's core business. Despite the ubiquity of university art galleries, little research has been undertaken regarding these organisations within the context of Aotearoa New Zealand. This dissertation explores this issue by examining the ways in which university art galleries have integrated themselves into their university communities.
\end{abstract}

This dissertation provides a general and concise overview of university art galleries in New Zealand and then presents two in-depth case studies, examining first the Gus Fisher Gallery and then the George Fraser Gallery at the University of Auckland. By utilising a wide range of sources including international and local theoretical literature, interviews, and documentation of public programmes and exhibition histories, these two case studies demonstrate that university art galleries contribute to their parent organisation in a variety of ways. These include serving as an important public interface for the university by showcasing academic and creative scholarship undertaken by the institution's staff, students, and alumni; acting as a vehicle through which the university can achieve strategic and academic goals and objectives, and assisting the university in fulfilling its duty to act as the "critic and conscience of society".

This dissertation makes a contribution to museum studies and current museum practice by addressing a gap in the New Zealand literature on this topic. It is the first critical academic analysis of university art galleries in this country situated in relation to British and American theory. In particular, it builds upon and refines Janet Marstine's argument that university art galleries can lead in the development of the Post-Museum and questions whether Marstine's theories can apply to the New Zealand context. 


\section{Acknowledgements}

This thesis is first and foremost dedicated to my mum, Philippa Baines. Thank you seems such an inadequate term to express how much I have appreciated your unwavering love and support throughout the past six years of my university studies.

My thanks must also be given to my supervisors Dr Conal McCarthy, Victoria University of Wellington, and Athol McCredie, the Museum of New Zealand Te Papa Tongarewa. I would also like to express my gratitude to Dr Lee Davidson and Annie Mercer at Victoria University of Wellington.

My sincere appreciation must go to those who assisted me with my research, especially Linda Tyler and Jaimee Stockman-Young at the University of Auckland, who took the time out their busy schedules to ensure I had all the information I required.

To my fellow Museum and Heritage Studies students, Alice Meads and Brenden Shirley, thank you for all your moral support, kind words, and much-needed coffee breaks. Thanks must also be given to my wonderful friends for their continual support throughout this journey and their complete willingness to distract me from my studies. A special thank you to Eve Williams, who gladly offered to proofread and edit my thesis.

I must thank my brother Sam Baines, who has always nurtured and encouraged my love of art. And finally, to my partner Chris Rowley, for his endless encouragement, support, and optimism - I could not have done this without you. 


\section{Table of Contents}

Non-Core Business? 1

An Examination of University Art Galleries in Aotearoa New Zealand 1

Abstract 1

Acknowledgements 1

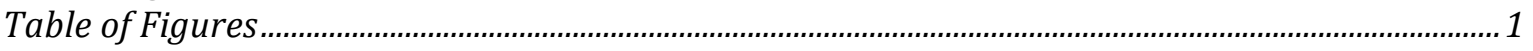

Introduction $\quad 1$

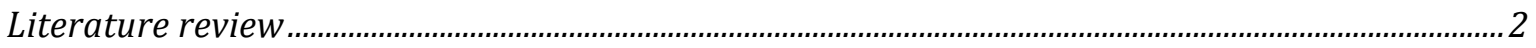

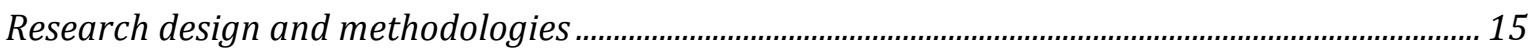

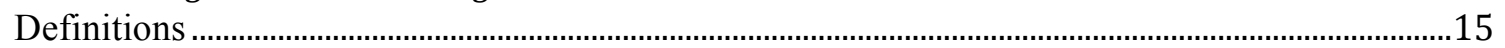

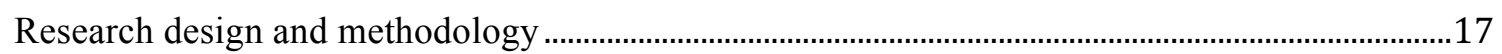

Chapter One: An Overview of University Art Galleries in New Zealand 22

The Adam Art Gallery Te Pātaka Toi ................................................................................................... 22

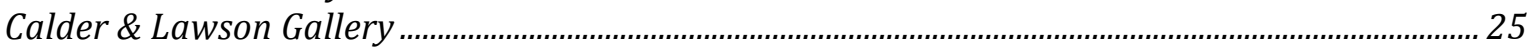

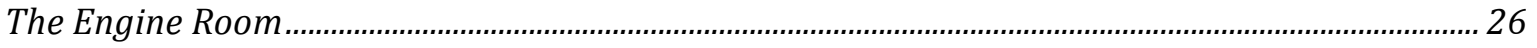

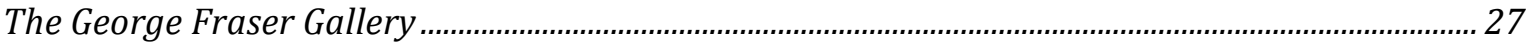

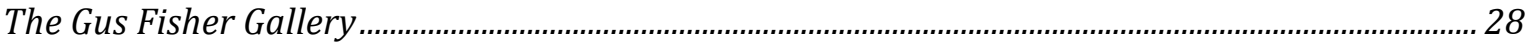

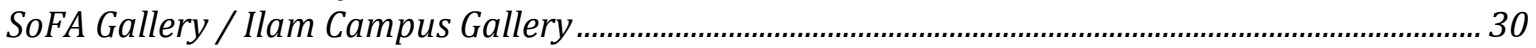

St Paul St Gallery ……......................................................................................................................... 32

The two types of university art galleries ………………........................................................................... 33

Advantages and challenges for New Zealand university art galleries ...............................................35

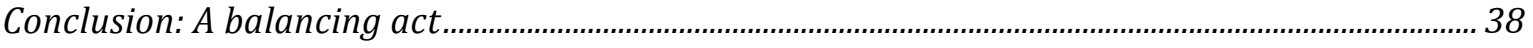

Chapter Two: The George Fraser Gallery at the University of Auckland 39

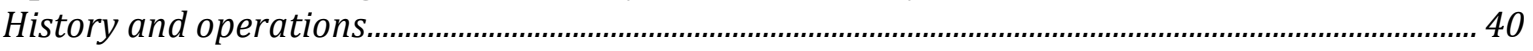

The George Fraser Gallery and its role within the University ............................................................... 42

The George Fraser Gallery and its role for the University .................................................................... 44

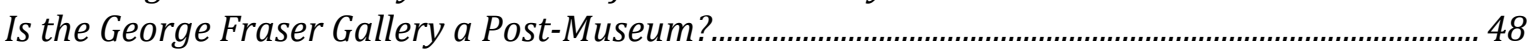

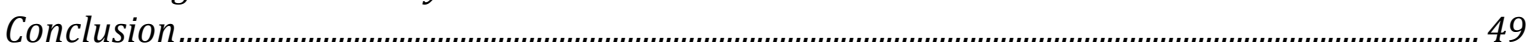

Chapter Three: The Gus Fisher Gallery at the University of Auckland 51

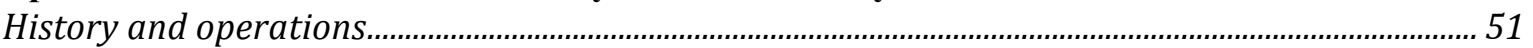

The Gus Fisher Gallery and its role within the University..................................................................... 54

The Gus Fisher Gallery and its role for the University ..................................................................... 58

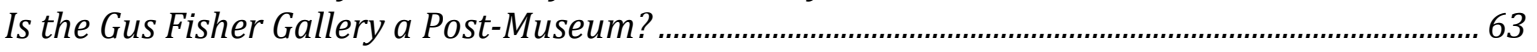

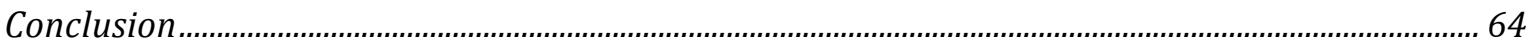

Conclusion: From the margins to the core $\quad 66$

$\begin{array}{ll}\text { Bibliography } & 73\end{array}$

$\begin{array}{lr}\text { Appendices } & \mathbf{8 8}\end{array}$

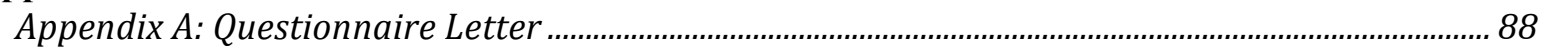

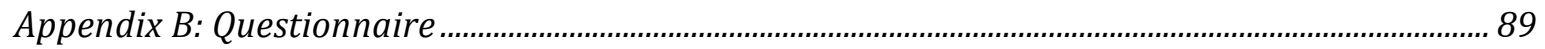

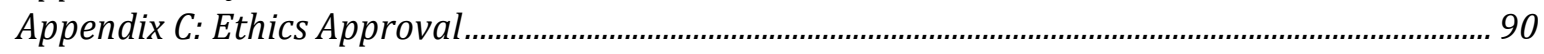

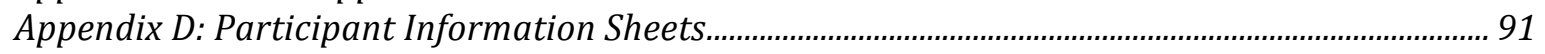

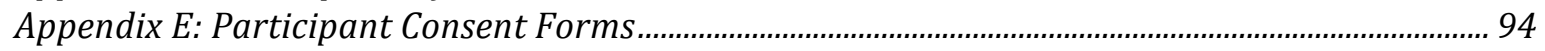

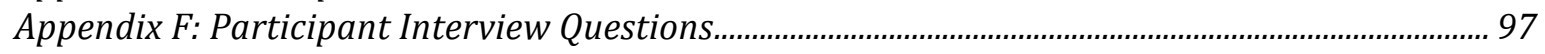




\section{Table of Figures}

Figure 1: The exterior of the George Fraser Gallery in Albert Park, Auckland. Image credit: Penelope Baines, 2014.

Figure 2: The exterior of the Gus Fisher Gallery, Shortland Street, Auckland. Image credit: Penelope Baines, 2014.

Figure 3: A class from the University of Auckland engineering department using the Gus Fisher Gallery. Image credit: Linda Tyler. 56 


\section{Introduction}

This dissertation provides an insight into university art galleries within Aotearoa New Zealand. I became interested in the subject of university art galleries while undertaking a curatorial internship at the Gus Fisher Gallery at the University of Auckland as part of a Master in Museum and Heritage Studies degree. During this placement I came to recognise the important role of the university art gallery and its art collection within the academic community. I came to see university art galleries and their collections as valuable alternative teaching tools and resources, and questioned whether New Zealand universities were utilising these facilities to their utmost potential. This is of considerable importance as six out of the eight universities in New Zealand have an art gallery affiliated with their institution. ${ }^{1}$ University art galleries are the most common form of campus museum in New Zealand, yet little is known about the ways in which they operate and how they engage with their university constituencies.

The subject of university museums and art galleries has received increasing recognition over the last two decades in academic and professional literature and has resulted in the establishment of a number of committees throughout the world, including the International Committee for University Museums and Collections (UMAC), a specialised committee of the International Council of Museums (ICOM). ${ }^{2}$ The broad subject of university museums is primarily dominated by the discussion of natural history and science museums, while the institution of the university art gallery remains largely overlooked. Furthermore, much of the scholarship concerning university museums has been researched by American, British, European, and Australian museum studies academics and is specific to those contexts. To my knowledge, very few New Zealand scholars have written about the subject of university art galleries in the context of New Zealand. Therefore, the purpose of this dissertation is to not only satisfy my own personal curiosity and interest in this subject, but to also contribute to the academic field of museums studies by providing a concise examination of the relationship

\footnotetext{
${ }^{1}$ Lincoln University and the University of Otago are the only New Zealand universities that do not have an art gallery affiliated with their institutions. However, the Hocken Library at the University of Otago does possess a gallery space which showcases a programme of regular exhibitions featuring works from the Pictorial Collection as well as artwork by Frances Hodgkins Fellows and travelling exhibitions.

${ }^{2}$ Other committees established prior to this date include the University Museum Group in the United Kingdom in 1987, and the Council of Australian Museums and Collections in 1992.
} 
between university art galleries in New Zealand and their wider cultural context, a subject upon which future researchers can build.

This dissertation examines how and why New Zealand university art galleries have, or have not, integrated themselves into their university communities. This overarching question gives rise to a number of other issues, including: how and why university art galleries contribute to the strategic and academic objectives of their parent organisations; in what ways do these institutions encourage and nurture student and staff involvement, and whether New Zealand university art galleries can be considered examples of the emerging Post-Museum. However, before going on to answer these questions, the international and local literature on this topic will be surveyed in order to construct a valuable theoretical basis for this research study.

\section{Literature review}

The fact that six out of the eight universities in New Zealand have an affiliated art gallery means that this type of institution is a common feature within this country's tertiary education providers. Despite their ubiquity however, there has been little research undertaken on university art galleries in Aotearoa New Zealand. ${ }^{3}$ The purpose of this literature review is to survey the international and local writing on university museums and galleries in order to provide a theoretical framework for this research and to identify and explore the main themes relating to university art galleries.

In 1942 Laurence Vail Coleman, the President of the American Association of Museums, sought to define the special nature of the university museum. He concluded that, "the campus museum should be, above all, an instrument of teaching or research or both." Coleman believed that "the first duty of a university or college museum is to its parent establishment, which means that faculty and the study body have a claim prior to that of townspeople and outsiders in general." ${ }^{, 4}$ Although Coleman was referring to university museums in general

\footnotetext{
${ }^{3}$ The exceptions are: Conal McCarthy, "The Politics of Display: Exhibiting in a Town/Gown Gallery," paper presented at A Conference on the Future of University Museums and Art Galleries in the New Century, Launceston, Tasmania, Australia, May, 2005; and Sophie McIntyre, "Thinking Out the Square: Orientating Aotearoa," paper presented at A Conference on the Future of University Museums and Art Galleries in the New Century, Launceston, Tasmania, Australia, May, 2005.

${ }^{4}$ Laurence Vail Coleman, College and University Museums: A Message for College and University Presidents (Washington DC: American Association of Museums, 1942), quoted in Laurel Bradley, "Curricular Connections: The College/University Art Museum as a Site for Teaching and Learning," CAA Reviews (New York: 12 August, 2009), http://www.caareviews.org/reviews/1309 (accessed 1 May, 2014). Please note: from
} 
rather than university art galleries specifically, his argument can also be appropriately applied to these institutions. This is because ever since their establishment, university art galleries have occupied an awkward position between the wider art gallery and museum community and their university constituency. Rather than embrace the values of the university environment in which they are located, many campus art galleries and museums identify themselves as civic art galleries situated on a university campus. In 2001, the American Association of Art Museum Directors stated: “...the broad goals and responsibilities of the independent art museum and the university/college art museum are essentially the same."5 Yet, 60 years prior to this statement, Coleman had warned against university museums aligning themselves too closely to the goals of their civic counterpart by arguing that "there are campus museums ... that try to be all things to all men; but unless such museums are conspicuously useful in their proper work - that is, work with students - they are inadequate, and no extenuating circumstances can alter that fact.",6

Coleman's arguments about the purpose and mission of university museums came to the fore in 2008 when the Financial Global Crisis forced many tertiary institutions to eliminate a number of "unessential" services and facilities. Consequently, a number of universities and colleges began to view their art museums, galleries, and collections as superfluous to the main mission of the parent institution. In 2009, Brandeis University in Massachusetts caused widespread controversy over its decision to close its campus art museum and sell its entire collection in order to ease the University's financial burdens. ${ }^{7}$ Since then, in order to prove their "worth" and "value", university art galleries have increasingly begun to align themselves with the academic and strategic mission of their parent organisation and engage with their university communities in order to promote their pedagogical importance. In doing so, university galleries have become increasingly thought of not only as "forums," "laboratories," and "portals" for the presentation of diverse and interdisciplinary academic ideas, but also as a model for the emerging museological paradigm of the Post-Museum. ${ }^{8}$

this point onwards all website references will only consist of an author, title and access date, please refer to the bibliography for the full reference.

${ }^{5}$ American Association of Art Museum Directors, Professional Practices in Art Museums (New York: AAMD, 2001), 19, quoted in Ibid.

${ }^{6}$ Coleman, 5, quoted in Ibid.

${ }^{7}$ Randy Kennedy and Carol Vogel, "Outcry Over a Plan to Sell Museum's Holdings," New York Times, 27 January, 2009 (accessed 9 February, 2015); Max Marmor, "Foreword," in Corrine Glesne, The Exemplary Museum: Art and Academic (Edinburgh and Boston, MA: MuseumsETC, 2013), 7.

${ }^{8}$ Anna Hammond, et al., "The Role of the University Art Museum and Gallery," Art Journal 65, no. 3 (Fall, 2006): 20-30; and Janet Marstine, "The Transformative Exhibition, the Museum Intervention, and the 
It is an interesting undertaking to place the longstanding tradition of the university art museum and gallery, which dates back to the establishment of the Ashmoleon Museum in 1683 , within the relatively young academic discipline of museum studies and related fields. Museological courses, which focused on the practical aspects of museum practice, were first offered by the Louvre Museum School in Paris during the 1880s. In America, the Pennsylvania Museum in Philadelphia offered similar courses in 1908, as did the Museums Association in the United Kingdom in $1930 .{ }^{9}$ In contrast, museum studies, which has been described as "the academic analysis of museum history, theory and practice, a critical examination of diverse aspects of museums within their social context" did not emerge until the 1960 s and 1970s. ${ }^{10}$ Museum Studies was established as a postgraduate university course at a small number of universities in America and the United Kingdom and drew its theory from a variety of related academic fields including art history, history, anthropology, sociology, and visual culture, as well as culture, gender, and leisure studies. ${ }^{11}$ However, it was not until the late 1980s with the emergence of the "New Museology" that museum studies began to establish a rich and significant theoretical grounding. ${ }^{12}$ The New Museology drew upon the theories posited in postmodernism and post-colonialism which critiqued and questioned Western master narratives as the authoritative voice within the museum. ${ }^{13}$

However, in 2013, Andrew Dewdney, David Dibosa and Victoria Walsh criticised the New Museology, arguing that its overly-theoretical concepts had now reached their limits and a new form of critical knowledge was required. In its place, the authors argued for a new model entitled Post-Critical Museology. According to Dewdney, Dibosa and Walsh, this theoretical framework signals "a break with the theoretical critique of the representational museum and calls for a return to empirical and pragmatic research." 14 They propose that Post-Critical

Transformative Pedagogy: New Museum Theory: What Students Need," paper presented at The College Museum: A Collision of Disciplines, A Laboratory of Perception Conference, Frances Young Tang Teaching Museum and Art Gallery, Skidmore College, Saratoga Springs, New York, 7-8 April, 2006.

${ }^{9}$ Bronwyn Labrum and Conal McCarthy, "Museums and Museum Studies: Bringing Together Theory and Practice," Te Ara Journal of New Zealand: Special Issue - Museum Studies in New Zealand 30, no. 2

(November, 2005): 5, 6 .

${ }^{10}$ Ibid., 6.

${ }^{11}$ Ibid., and Conal McCarthy and Joanna Cobley, "Museums and Museum Studies in New Zealand: A Survey of Historical developments," History Compass 7, no. 2 (2009): 396.

${ }^{12}$ See: Peter Vergo, ed., The New Museology (London: Reaktion Books, 1989).

${ }^{13}$ McCarthy and Cobley, "Museums and Museum Studies," 404-405.

${ }^{14}$ Andrew Dewdney, David Dibosa, and Victoria Walsh, Post-Critical Museology: Theory and Practice in the Art Museum (London and New York: Routledge, 2013), 16. 
Museology welds both museological theory and practice together in order to form a method that reflects "the interests of its own practices rather than the concerns of the academy."15

Post-Critical Museology highlights the continual tension between the nexus of theory and practice which has featured prominently within the discipline of museum studies ever since universities began to offer courses in the subject. As a profession previously learned through practical training within the museum, the introduction of museum studies into the theoretical and academic context of the university raised significant debate. ${ }^{16}$ According to Labrum and McCarthy: "The 'boom' in university courses redressed naïve notions of practical skillsbased training but some argue that this went too far by constructing a theoretical framework for the study of museums at the expense of professional concerns." ${ }^{17}$ However, McCarthy and Cobley argue that the introduction of the New Museology "... dismantled the separation of theory and practice, dissolving the stereotype of pragmatic professionals and impractical academics and instead seeing them as "two sides of the same coin." ${ }^{18}$ Consequently, a new model of museum studies has emerged which combines both theory and practice as can be seen in Dewdney, Dibosa and Walsh's theoretical framework of Post-Critical Museology. ${ }^{19}$

So, where does the subject of university art galleries fit within the ever-expanding literature on museum studies? Surveying a number of general anthologies which have emerged since the start of the millennium, including Gerard Corsane's Heritage, Museums and Galleries; Sharon Macdonald's A Companion to Museum Studies; Gail Anderson's Reinventing the Museum, and Bettina Messias Carbonell's Museum Studies, not only is the subject of university art galleries absent, but the topic of university museums in general is omitted. ${ }^{20}$ The only museum studies anthology which addresses university art museums and galleries is Janet Marstine's New Museum Theory and Practice: An Introduction, which includes an

\footnotetext{
15 Ibid., 17.

${ }^{16}$ For a discussion on this subject see: Labrum and McCarthy, "Museum Studies and Museums"; and McCarthy and Cobley, "Museums and Museum Studies in New Zealand."

${ }^{17}$ Labrum and McCarthy, "Museums and Museum Studies in New Zealand," 7.

${ }^{18}$ Labrum and McCarthy, "Museums and Museum Studies in New Zealand," 4, quoted in McCarthy and Cobley, "Museums and Museum Studies, 405.

${ }^{19}$ Labrum and McCarthy, "Museums and Museum Studies in New Zealand," 7; See also: Suzanne MacLeod, "Making Museum Meanings: Training Education, Research and Practice," Museum Management and Curatorship 19, no. 1 (2001): 51-61; and Conal McCarthy, ed., Museum Practice, vol. 4, The International Handbooks of Museum Studies (Oxford and Malden, MA: Wiley Blackwell, 2015).

${ }^{20}$ Gerard Corsane, ed., Heritage, Museums and Galleries: An Introductory Reader (London and New York, NY: Routledge, 2005); Sharon Macdonald, ed., A Companion to Museum Studies (Malden, MA: Blackwell Publishing, 2006); Gail Anderson, ed., Reinventing the Museum: The Evolving Conversation on the Paradigm Shift (Lanham, MD: AltaMira Press, 2012); and Bettina Messias Carbonell, ed., Museum Studies: An Anthology of Contexts (Chichester: Wiley-Blackwell, 2012).
} 
entire article dedicated to the topic, entitled, "The University Museum and Gallery: A Site for Institutional Critique and a Focus of the Curriculum. ${ }^{21}$ Museums and Universities: New Paths for Continuing Education edited by Janet W. Solinger was published well over a decade ago and deals specifically with the relationship between museums and universities. Surprisingly, however, there is little reference to university museums and many of the articles are written by non-university museum professionals and academics. ${ }^{22}$

Despite the general lack of literature concerning university art museums, two articles written by John Spencer in 1972 and Alan Warhurst in 1986 set the scene for these institutions within the discipline of museum studies. ${ }^{23}$ Unfortunately, Spencer and Warhurst presented a rather dire situation, stating that university museums were in the midst of an identity crisis and were without a defined role in a rapidly changing environment. ${ }^{24}$ It was not until September 2000 that the subject of university museums re-emerged with the conference "Managing University Museums," sponsored by the Organisation for Economic Cooperation and Development. This conference and its subsequent publication provided a forum for the discussion of four aspects relating to university museums: roles and challenges; raising awareness and forming partnerships; identifying parallels and establishing partnerships with private businesses, and a series of case studies on individual university museums. ${ }^{25}$ Another reason why the subject of university museums resurfaced in 2000 may be due to the establishment of the International Committee for University Museums and Collections (UMAC) as part of the International Committee of Museums (ICOM) during that same year.

The dire situation for university museums presented by Spencer and Warhurst continued to dominate the literature surrounding the subject up until 2006-2007. This is evident in the

\footnotetext{
${ }^{21}$ Lyndel King and Janet Marstine, "The University Museum and Gallery: A Site for Institutional Critique and a Focus of the Curriculum," in New Museum Theory and Practice: An Introduction, ed. Janet Marstine (Oxford and Malden, MA: Blackwell Publishing, 2006), 266-291.

22 Janet W. Solinger, ed., Museums and Universities: New Paths for Continuing Education (New York, NY: Macmillan, 1990). Aldona Jonaitis also had the same criticisms, see: Aldona Jonaitis, "Joining the $21{ }^{\text {st }}$ Century While Remaining Honest to Our Mission as University Museums," paper presented at New Roads for University Museums $-6^{\text {th }}$ International Congress for University Museums, Mexico City, Mexico, 2006.

${ }^{23}$ John R. Spencer, "The University Museum: Accidental Past, Purposeful Future?," Art in America 59, no. 4 (1971): 59-84; and Alan Warhurst, "Triple Crisis in University Museums," Museums Journal 86, no. 3 (December, 1986): 137-140.

${ }^{24}$ Warhurst, "Triple Crisis in University Museums," cited in Peter Stanbury, "Adding Value to University Collections," paper presented at Intensifying Support For and Increasing Audiences in University Museums and Collections, Proceedings of the First Conference of the International Committee of ICOM for University Museums and Collections, Barcelona, Spain, 2-4 June, 2001.

${ }^{25}$ Melanie Kelly, ed., Managing University Museums (Paris: Organisation for Economic Cooperation and Development, 2001).
} 
number of texts that acknowledge the extent to which university museums are vulnerable to the whims of their parent organisations and provide advice on the ways in which these institutions can promote their academic and cultural value to their universities. The vulnerability of university museums was a result of the significant move by tertiary education providers during the 1980 s to adopt a managerial style of operations. ${ }^{26}$ As a result of this shift, university museums were forced to prove how their institution contributed to the core business of the parent organisation. Most, if not all, of the text concerning this topic advised university museums to align their activities with the teaching and research objectives of their universities. ${ }^{27}$ Furthermore, an increasing number of writers postulated that an additional role of the university museum should be to act as an interface between the public and the university. ${ }^{28}$ It was suggested that universities could utilise the campus museum as a vehicle to communicate their scholarship activities to the public, subsequently fulfilling the university's responsibility to assist in the education of its students as well as the wider community. ${ }^{29}$

The need for university art galleries to prove their worth as a pedagogical tool and cultural resource for their parent institution was the impetus behind a study initiated by the Andrew W. Mellon Foundation in the United States during the 1990s. This study, entitled the College University Art Museums (CUAM) Program was commissioned by the Mellon Foundation due to concerns that university art museums and galleries were "becoming divorced from the academic pursuits" of their parent organisation and, consequently "losing some of their education value." ${ }^{30}$ The CUAM Program consisted of a series of endowments aimed at developing and enhancing collaboration between art museums and academic departments, and strengthening the educational role of university art museums. The results showed that the

\footnotetext{
${ }^{26}$ Gina Hammond, Karl van Dyke, and Andrew Simpson, "Adding Value: Universities and Their Museums," University Museums and Collections Journal 5 (2012): 7; and Pierre de Maret, "Exposing the Ivory Tower," paper presented at Awareness and Action - University Museums Today, Uppsala, Sweden, 25 September - 1 October, 2005.

${ }^{27}$ For example see: Ted Snell, "Valuing University Art Galleries," paper presented at A Conference of the Future of University Museums and Art Galleries in the New Century, Launceston, Tasmania, Australia, May, 2005; and Sue-Anne Wallace, "Challenges Facing University Museums," paper presented at Intensifying Support For and Increasing Audiences in University Museums and Collections, Proceedings of the First Conference of the International Committee of ICOM for University Museums and Collections, Barcelona, Spain, 2-4 June, 2001.

${ }^{28}$ Wallace, "Challenges Facing University Museums"; and Vanessa Mack, "The Dual Role of University Museums: Its Influence on Management," in Managing University Museums, ed. Melanie Kelly (Paris: OECD, 2001), 29-35.

${ }^{29}$ Melanie Kelly, "Introduction," in Ibid., 11-12.

${ }^{30}$ Marion M. Goethals and Suzannah Fabing, College and University Art Museums Program (New York, NY: Andrew W. Mellon Foundation, November, 2007).
} 
CUAM Program helped university art museums to become more involved in a far greater range of educational activities within their institution through initiatives such as internships, fellowships, courses, symposia, and exhibition development projects. ${ }^{31}$ This, however, is rather unsurprising as the significant endowments provided by the Mellon Foundation provided participating art museums and galleries with the exceptional circumstance of financial freedom. Nevertheless, the CUAM Program revealed the potential of university art museums and galleries to contribute to and engage with the academic and extra-curricular agendas of their parent organisations.

A similar study was also recently undertaken by the Samuel H. Kress Foundation which aimed to identify the long-term educational value of university art museums and galleries. ${ }^{32}$ The study investigated four main research questions which focussed on: university art museums' integration into the academic activities of their parent institution; extra-curricular interactions between the university art museums, students and faculty; the institutional structures that are supportive and obstructive to university art museums, and how artwork donated to universities by the Kress Foundation have been used. ${ }^{33}$ The last of these research topics meant that the study was restricted to those universities that had been recipients of Kress Foundation donations but attempts were made to incorporate as wide a variety of universities as possible. ${ }^{34}$

The conclusions of the Kress Foundation study and the CUAM Program report brought forward two significant themes which, from 2006 onwards, dominate the literature concerning university art museums and galleries. The first of these themes is the idea of the university art museum and gallery as a site and tool for academic learning, and the second is the concept of the university gallery as a "forum," "laboratory," or "portal" for the presentation of diverse and interdisciplinary ideas. ${ }^{35}$

The first of these themes is discussed by Laurel Bradley in her article "Curricular Connections: The College/University Art Museum as a Site for Teaching and Learning." In this article, Bradley discusses the shift of American university art museums and galleries

\footnotetext{
${ }^{31}$ Ibid., 9-10, 22-29.

${ }^{32}$ Glesne, The Exemplary Museum: Art and Academia.

${ }^{33}$ Ibid., 12.

${ }^{34}$ Ibid., 13-14.

${ }^{35}$ Ibid., 256; and Goethals and Fabing, College and University Art Museums Program, 29.
} 
from being a "community museum on a college campus" to "an active site for teaching and learning for students and faculty not only in the disciplines of studio art and art history but all across the curriculum." ${ }^{36}$ In examining this shift, Bradley draws upon the research presented in a number of forums, including the CUAM Program report, articles by Janet Marstine and Elizabeth Rodini, as well as papers presented at two conferences held in 2006 - "The College Museum: A Collision of Discipline, A Laboratory of Perception" and "Creator, Collector, Catalyst: The University Art Museum in the Twenty-First Century." Bradley also uses the Frances Young Tang Teaching Museum and Art Gallery at Skidmore College in Saratoga Springs, New York, as an example of this new type of "curriculum-focused, interdisciplinary campus art museum." 37

The Kress Foundation Study and the CUAM Program report, as well as a number of other publications, provide specific examples of the ways in which university art museums and galleries have established themselves as a teaching tool and resource for a wide range of academic disciplines within the university. ${ }^{38}$ However, an important offshoot of this discussion has been the importance of museum literacy within undergraduate education. ${ }^{39}$ Elizabeth Rodini, director of the museum studies programme at John Hopkins University, argues that museum literacy should be a significant part of a university education in order to ensure that graduates become "informed consumers of culture." 40 Rodini's argument is based on the claim that audiences place immense trust in museums as these institutions are one of the most important and influential sites of learning. ${ }^{41}$ Despite this, the majority of museum audiences do not possess the critical framework required to analyse the institution of the museum or its exhibitions; consequently, many visitors continue to view the museum as a

\footnotetext{
${ }^{36}$ Bradley, "Curricular Connections".

${ }^{37}$ Ibid.

${ }^{38}$ Glesne, The Exemplary Museum, 74-152; Goethals and Fabing, College University Art Museums Program, 910, 22-29; Lyndel King, "Engaging University Students," paper presented at Intensifying Support For and Increasing Audiences in University Museums and Collections, Proceedings of the First Conference of the International Committee of ICOM for University Museums and Collections, Barcelona, Spain, 2-4 June, 2001; and Malcolm Bywaters, "The Role of the Regional University Gallery, Case Study: The Academy Gallery, Launceston," paper presented at A Conference on the Future of University Museums and Art Galleries in the New Century, Launceston, Tasmania, Australia, May, 2005.

${ }^{39}$ See: Carin Jacobs, et al., "Beyond the Field Trip: Museum Literacy and Higher Education," Museum Management and Curatorship 24, no. 1 (2009): 5-27.

${ }^{40}$ Elizabeth Rodini, "The Ivory Tower and the Crystal Palace: Universities, Museums and the Potential of Public Art History,” CAA Reviews (accessed 1 May, 2014).

${ }^{41}$ James Cuno, "Introduction" in Whose Muse? Art Museums and the Public Trust, ed. James Cuno (Oxford and Princeton, NJ: Princeton University Press, 2004), 18, cited in Ibid. Also see: Eilean Hooper-Greenhill, "Changing Values in the Art Museum: Rethinking Communication and Learning," in Museum Studies: An Anthology of Contexts, ed. Bettina Messias Carbonell (Oxford and Malden, MA: Blackwell Publishing, 2004), 557.
} 
temple of truth and knowledge. Rodini argues that universities, and in turn the university art museum and gallery, should be concerned with teaching students to have the same critical stance with museum exhibitions as they do with other cultural media such as television, movies, advertising, and newspapers. ${ }^{42}$

This argument was also put forward by the American artist, Fred Wilson, and academic Janet Marstine. Wilson and Marstine argue that critical museum theory should be an integral part of the university curriculum as it enables students to identify and critique the carefully constructed social narratives produced through the communicative concept of framing. ${ }^{43}$ Donald Presziosi explains that,

Framing is a metaphorical process that creates a vision of the past and future based on contemporary needs. ... Frames not only set boundaries; they provide an ideologically based narrative context that colours our understanding of what's included. $^{44}$

Accordingly, framing within the museum is subtle and yet powerful, controlling the viewing process in order to "suggest a tightly woven narrative of progress, an 'authentic' mirror of history, without conflict or contradiction." 45

The concept of the university art gallery as a forum, laboratory, or portal for the presentation of diverse and interdisciplinary ideas also emerges in a number of texts which discuss the purpose, role, and potential of university art galleries. According to Rodini, the analogy of the university art gallery as a laboratory has a long tradition in the American context. It first emerged during the 1920s when Edward W. Forbes and Paul J. Sachs founded the Fogg Art Museum at Harvard University. Forbes and Sachs intended this museum to be a "Laboratory of the Fine Arts," which would equip art historians with practical experience in handling

\footnotetext{
${ }^{42}$ Rodini, "The Ivory Tower and Crystal Palace."

${ }^{43}$ Adam Weinberg and Fred Wilson, "College Museums: A Visual Laboratory?” dialogue presented at The College Museum: A Collision of Disciplines, A Laboratory of Perception Conference, Frances Young Tang Teaching Museum and Art Gallery, Skidmore College, Saratoga Springs, New York, 7-8 April, 2006; Janet Marstine, "Introduction," in New Museum Theory and Practice: An Introduction, ed. Janet Marstine (Oxford and Malden, MA: Blackwell Publishing, 2006), 4-5.

${ }^{44}$ Donald Presziosi, Brain of the Earth's Body: Art, Museums, and the Phantasms of Modernity (Minneapolis: University of Minnesota Press, 2003), cited in Marstine, New Museum Theory and Practice, 4.

${ }^{45}$ Weinberg and Wilson, "College Museums"; Marstine, New Museum Theory, 5.
} 
objects and materials. Their use of the term "laboratory" was an attempt to align the subject of art history with the seriousness of scientific disciplines such as chemistry and physics. ${ }^{46}$

This idea is also explored by Sharon Macdonald and Paul Basu in their publication Exhibition Experiments. ${ }^{47}$ Here, the authors make note of the similar objectives of experiments and exhibitions by highlighting that Steven Shapin and Simon Schaffer "... argue that the purpose of scientific apparatus is 'to make visible the invisible' - in other words, to exhibit, to 'hold out,' to display." ${ }^{48}$ Macdonald and Basu subsequently go on to argue that exhibition “... is a site for the generation rather than reproduction of knowledge and experience," and subsequently conceive of exhibitions “... as a kind of laboratory, in which, ... various 'actants' (visitors, curators, objects, technologies, institutional and architectural spaces, and so forth) are brought into relation with each other with no sure sense of what the result will be." Therefore, the current use of the term "laboratory" within the context of the university art gallery refers to the way in which these institutions can collaborate with various communities in order to provide exhibitions that not only attract and appeal to their constituencies, but also interrogate institutional narratives and modes of display. ${ }^{50}$

This concept became evident at the 2006 American College Art Association's annual conference, where the Art Journal editorial board convened a round-table discussion with eight university art museum and gallery directors. ${ }^{51}$ One of the key themes that emerged from their conversation was the way in which all of these university art museums and galleries strived to promote their institutions as a laboratory for critical and interdisciplinary thinking and experimentation. ${ }^{52}$ According to Sharon Corwin, "the model of the paradigm of the

\footnotetext{
${ }^{46}$ Kathryn Bush, Vastly More Than Bricks and Mortar: Reinventing the Fogg Art Museum in the $1920 \mathrm{~s}$ (Cambridge, MA: Harvard University Art Museums, 2003), cited in Rodini, "The Ivory Tower and the Crystal Palace."

${ }^{47}$ Sharon Macdonald and Paul Basu, eds., Exhibition Experiments (Oxford and Malden, MA: Blackwell Publishing, 2007).

${ }^{48}$ Sharon Macdonald and Paul Basu, "Introduction: Experiments in Exhibition, Ethnography, Art, and Science," in Ibid., 2.

${ }^{49}$ Ibid.

${ }^{50}$ Rodini, "The Ivory Tower and the Crystal Palace". McCarthy also discusses this in "The Politics of Display."

${ }^{51}$ This comprised of Anna Hammond, Deputy Director for education, programs, and public affairs at Yale University Art Gallery; Ian Berry, Associate Director at the Francis Young Tang Teaching Museum and Art Gallery; Sheryl Conkelton, Director and Chief Curator at Colby College Museum of Art; Pamela Franks, Curator for academic initiatives at Yale University; Katherine Hart, Associate Director of the Hood Museum of Art; Wyona Lynch-McWhite, Director of the Eleanor D. Wilson Museum; Charles Reeve, Curator at Ontario College of Art and Design; and John Stomberg, Deputy Director at Williams College Museum of Art.

${ }^{52}$ Anna Hammond, et al., "The Role of the University Art Museum and Gallery," 22-25.
} 
laboratory is perfect because it's a place to experiment, ask questions and really take risks.",53 For these directors it is this characteristic - the potential to incite, nurture and display radical thinking - that distinguishes university art museums and galleries from their civic counterparts.

This idea was further explored by Marstine and Lyndel King who argued that university art museums and galleries are conducive environments for interdisciplinary learning, radical thinking, and institutional critique because "they operate in an academic climate where the questioning of authority is encouraged." ${ }^{, 54}$ As examples, King and Marstine examine the Weisman Art Museum at the University of Minnesota and the Frances Young Tang Teaching Museum and Art Gallery at Skidmore College. These tertiary institutions commissioned the artists, Mark Dion and Fred Wilson to create projects that encouraged students to challenge the disciplinary parameters of the museum as well as the university.

Nick Prior also broaches the concept of institutional critique within the art museum and argues that "institutional self-consciousness is an increasingly predominant feature of the modernisation of all organisations in contemporary society." 55 According to Prior, museums are able to "inhabit a more democratic, open-ended "third-space"" by practicing "institutional reflexivity," which is "a process of self-examination through which the institution comes to know itself better, questioning its own auspices and social function. ${ }^{56}$ Thus, this process enables the museum to establish more socially inclusive and progressive public programmes and exhibitions. ${ }^{57}$

Marstine and McCarthy appropriate Prior's idea of the "democratic open-ended 'third-space"” and apply it to the context of the university art gallery. Both of these authors argue that the university art gallery occupies a unique position on the fringe of both the university and municipal gallery environments. According to McCarthy, university art galleries are liminal entities and it is this liminality which enables them to be "free to experiment not only with

\footnotetext{
${ }^{53}$ Ibid., 23.

${ }^{54}$ King and Marstine, "The University Museum and Gallery," 268.

${ }^{55}$ Nick Prior, "Having One's Tate and Eating It: Transformations of the Museum in a Hypermodern Era," in Art and it Publics: Museum Studies at the Millennium, ed. Andrew McClellan (Oxford and Malden, MA: Blackwell Publishing, 2003), 67.

${ }^{56}$ Ibid., 68, 67.

${ }^{57}$ Ibid., 68 .
} 
new forms of artistic practice but with discourses that shape our ways of thinking about art.",58 Marstine also argues that "the third space of the university museum can develop interdisciplinary, open-ended projects without forgone conclusions that can foster multilayered connections and contradictions rather than linear exegesis." ${ }^{, 59}$ For Marstine, this characteristic of the university art gallery as a third space is conducive to staging "messy" and radical curatorial projects by undergraduate students. ${ }^{60}$ These student-driven exhibitions provide students with a forum to communicate their critical examinations and enable them to analyse the connections between the gallery's purpose and activities with their own academic work. In doing so, the university art gallery reinforces its unique mission as a pedagogical tool. ${ }^{61}$

According to Marstine, the characteristic of the university art gallery as a third space means that these institutions have the potential to lead the creation of the Post-Museum. The concept of the Post-Museum was first postulated by museum theorist, Eilean Hooper-Greenhill in Museums and the Interpretation of Visual Culture published in $2000 .^{62}$ Hooper-Greenhill used this term to refer to a new and reinvented museum-like institution which Marstine has described as:

...an institution that clearly articulates its agenda, strategies, and decisionmaking processes and continually re-evaluates them in a way that acknowledges the politics of representations. It shares power with the communities its serves, including source communities. The Post-Museum listens and responds sensitively as it encourages diverse groups to become active participants in museum discourse. It does not shy away from difficult issues, but exposes conflict and contradiction. ${ }^{63}$

The ability of university art galleries to stage exhibitions that critique institutional narratives and conventions enables these institutions to lead the way in establishing new museological practices and theory. However, in order to become a model for the Post-Museum, Marstine argues that university art galleries must accept three central responsibilities. The first of these is to embody Prior's notion of institutional reflexivity by initiating museum interventions that

\footnotetext{
${ }^{58}$ McCarthy, "The Politics of Display."

59 Janet Marstine, "What a Mess! Claiming a Space for Undergraduate Student Experimentation in the University Museum," Museum Management and Curatorship 22, no. 3 (2007): 303.

${ }^{60}$ Ibid.

${ }^{61}$ Marstine, "The Transformative Exhibition, the Museum Intervention, and the Transformative Pedagogy."

${ }^{62}$ Eilean Hooper-Greenhill, Museums and the Interpretation of Visual Culture (London and New York: Routledge, 2000), 8, 142-145, 152-153.

${ }^{63}$ Marstine, "The Transformative Exhibition, the Museum Intervention, and the Transformative Pedagogy." Also see Marstine, "Introduction," New Museum Theory and Practice, 19.
} 
include student and staff involvement or through student-driven exhibitions. These types of museum interventions will enable museum staff and audiences to participate in a critical discourse on the nature of power and representation. Secondly, the university art gallery must embrace the conclusions of this self-reflexive enterprise and implement them throughout the entire museum. This could be as simple as declarative wall texts which provide transparency and empower students, faculty, and administrators to become equal partners in the learning process. The last of these responsibilities is to teach students critical museum theory and infuse this subject throughout multiple disciplines, which enables not only the university art gallery, but also the entire university, to become a laboratory for critical thinking. ${ }^{64}$

University art galleries are a common feature upon the campuses of New Zealand universities; however, little academic research has been undertaken in regards to these institutions. This reflects a wider museological trend in which university art galleries have generally been overlooked in favour of their civic counterparts. What little literature there is on university art galleries is predominantly written by British, American, European, and Australian authors, who write very specifically about their own contexts. This is somewhat problematic as the structure of overseas tertiary institutions does not necessary parallel that of New Zealand. Moreover, much of the literature that discusses the innovative practices of university art museums and galleries is usually confined to prestigious and well-funded universities and colleges, especially in regards to the United Kingdom and American contexts.

This thesis, therefore, will address an evident gap in the literature and examine the institution of the university art gallery within the context of New Zealand Aotearoa. This study will present a detailed analysis of two New Zealand university art galleries in order to examine how and why these institutions have or have not integrated themselves into their university communities. In association with the theoretical overview I have just presented, I have also employed Dewdney, Dibosa, and Walsh's model of Post-Critical Museology. This theoretical framework intertwines both theoretical and empirical methods and has enabled me to examine whether New Zealand university art galleries can be considered innovative forums, laboratories, and portals for the presentation of diverse and interdisciplinary academic ideas. By doing so, I have been able to explore the ways in which university art galleries contribute to their parent organisation as well as reflect upon Marstine's argument as to whether New

\footnotetext{
${ }^{64}$ Marstine, "The Transformative Exhibition, the Museum Intervention, and the Transformative Pedagogy."
} 
Zealand university art galleries have the ability to lead in the creation of the Post-Museum.

The examination of these issues is an important factor within the New Zealand museum and gallery sector due to the prevalence of these institutions which have remained relatively unnoticed until this time.

\section{Research design and methodologies}

The review above showed that there exists little academic research on this country's university art galleries. In examining the literature concerning this topic, it has been shown that university art galleries are increasingly being thought of as innovative and interdisciplinary forums, laboratories, and portals that have the potential to lead in the creation of the Post-Museum. ${ }^{65}$ Although this theoretical framework is intriguing and provocative, it gives rise to the question of whether these theories can be applied in the New Zealand context. Therefore, alongside the theoretical framework I have outlined, I have also undertaken qualitative research in order to examine contemporary practice within New Zealand university art galleries. The overarching question of this investigation explores how and why New Zealand university art galleries have or have not integrated themselves with their university communities. This query gives rise to a number of other issues, including the ways in which university art galleries contribute to the strategic objectives of their parent organisation; whether these institutions encourage and nurture student and staff involvement, and the question of whether New Zealand university art galleries can be considered examples of the emerging Post-Museum.

\section{Definitions}

First, it will be helpful to define what this study classifies as an art gallery. The term "gallery" has slightly different connotations in the contexts of the United States and the United Kingdom. In North American usage, "gallery" often refers to a private or commercial space in which artworks are displayed and/or sold, while the term "art museum" is typically used to describe a non-profit organisation that displays artworks for the enjoyment and education of the public. In the United Kingdom and other Commonwealth countries, this type

\footnotetext{
${ }^{65}$ Anna Hammond et al., "The Role of the University Art Museum and Gallery," 23-25; and Ibid.
} 
of institution is usually referred to as an art gallery rather than an art museum. According to the Canadian Art Museum Directors Organisation:

Art museums collect historical and modern works of art for educational purposes and to preserve them for future generations. Public galleries on the other hand, do not in general collect or conserve works of art. Rather they focus on exhibitions of contemporary works as well as programmes of lectures, publications and other events. ${ }^{66}$

It could be said that both of these terms are applicable to New Zealand university art galleries. Although these institutions are concerned with providing programmes of short-term modern and contemporary art exhibitions, a number of them are also responsible for the management, care, and development of their university's art collection, which may consist of historical, modern, and contemporary artworks. Subsequently, when referring to the context of the United Kingdom and New Zealand, the term "art gallery" will be used, while "art museum" will be utilised when referring to institutions in the American context.

The term "university" and the rationale for selecting these organisations may also need explanation. There are a number of different kinds of tertiary providers in New Zealand, these include: universities, polytechnics, colleges of education, specialist colleges, and wānanga. ${ }^{67}$ Many of these institutions have some form of art gallery or space dedicated to the display of visual art. For instance, the contemporary art gallery RAMP is located at Wintec's School of Media and Arts in Hamilton, and Christchurch Polytechnic Institute of Technology has establish ArtBox, a building precinct intended to be used as a space for the display of visual arts and design. ${ }^{68}$ However, for the purposes of this research, this study was limited to the investigation of art galleries affiliated with a university institution. Under Section 162 of the Education Act (1989) a university is defined as having all of the following characteristics:

(i) They are primarily concerned with more advanced learning, the principal aim being to develop intellectual independence;

(ii) Their research and teaching are closely interdependent and most of their research is done by people who are active in advancing knowledge;

(iii) They meet international standards of research and teaching;

(iv) They are a repository of knowledge and expertise;

\footnotetext{
${ }^{66}$ Canadian Art Museum Directors Organisation, Organisation de Directeurs des Musées de’Art du Canada "What is an Art Museum?" (accessed 27 August, 2014).

${ }^{67}$ Kerryn Pollick, “Tertiary Education," Te Ara - The Encyclopedia of New Zealand (accessed 27 August, 2014).

${ }^{68}$ See: Ramp Gallery (accessed 9 February, 2014); and Christchurch Polytechnic Institute of Technology,

“About ArtBox" (accessed 2 February, 2015).
} 
(v) They accept a role as critic and conscience of society. ${ }^{69}$

According to Te Pōkai Tara Universities New Zealand, the representative body for New Zealand universities, there are eight universities in New Zealand. They are: Auckland University of Technology, Lincoln University, Massey University, the University of Auckland, the University of Canterbury, the University of Otago, the University of Waikato, and Victoria University of Wellington. ${ }^{70}$ Out of these eight universities, only Lincoln University and the University of Otago do not have an art gallery affiliated with their institution, ${ }^{71}$ while the University of Auckland is the only organisation which has two art galleries - the Gus Fisher Gallery and the George Fraser Gallery.

\section{Research design and methodology}

In their guide to designing qualitative research, Catherine Marshall and Gretchen Rossman argue that qualitative methodology is best used in research that examines "little known phenomena or innovative systems." 72 This research dissertation incorporates both aspects of this statement because the subject of university art galleries is a little known phenomenon in the field of museum studies within New Zealand. In regards to the concept of "innovative systems," the objective of this study is to examine the ways in which university art galleries have integrated themselves into their university communities. Subsequently, this research identifies and reveals innovative pedagogical and administrative practices and systems adopted by New Zealand university art galleries.

According to Michael Patton, "a qualitative case study seeks to describe the unit in depth and detail, holistically and in context." ${ }^{, 73}$ Marshall and Rossman inform us that case studies may entail multiple methods, including interviews, observation, and document analysis. ${ }^{74}$ As with

\footnotetext{
${ }^{69}$ New Zealand Education Act 1989, pt 14, s 162.

${ }^{70}$ Te Pōkai Tara University New Zealand, “The NZ University System” (accessed 31 August, 2014).

${ }^{71}$ The Hocken Library at the University of Otago does incorporate a gallery space and provides a series of exhibition throughout the year. However, due to its situation within the Library, it takes a different format to the art galleries that are affiliated with the other New Zealand universities. Therefore, I have not classified this space as a university art gallery in its own right.

${ }^{72}$ Catherine Marshall and Gretchen B. Rossman, Designing Qualitative Research, $5^{\text {th }}$ ed. (Thousand Oaks, CA: Sage, 2011), 90-91.

${ }^{73}$ Michael Quinn Patton, Qualitative Research and Evaluation Methods, $3^{\text {rd }}$ ed. (Thousand Oaks, CA: Sage, 2003), 55

${ }^{74}$ Marshall and Rossman, Designing Qualitative Research, 94.
} 
all forms of data collection, these methods possess both strengths and weaknesses. However, Patton states:

By using a combination of observations, interviewing and document analysis, the fieldworker is able to use different data sources to validate and crosscheck findings. ... Using a combination of data types ... increases validity as the strengths of one approach can compensate for the weaknesses of another approach. $^{75}$

My research began by sending an open-ended questionnaire to the seven university art galleries in New Zealand. These included: the Adam Art Gallery (Victoria University of Wellington), Calder \& Lawson Gallery (the University of Waikato), the Engine Room (Massey University, Wellington), the George Fraser Gallery (the University of Auckland), the Gus Fisher Gallery (the University of Auckland), School of Fine Arts Gallery/Ilam Campus Gallery (the University of Canterbury), and St Paul's St Gallery (Auckland University of Technology). In discussing the different methods of qualitative research, Patton describes the open-ended questionnaire as "the most elementary form of qualitative data." 76 He states that there are severe limitations to this form of data collection, such as the quality of respondents' writing skills, the impossibility of probing responses, and the effort required on behalf of the respondent to complete the questionnaire. ${ }^{77}$ However, I believe that this formative survey sufficiently provided the qualitative information that was necessary for me to select two university art galleries and examine them in the form of case studies.

Out of the seven university art galleries that were sent the questionnaire, six completed and returned the survey. Five of the galleries did this via e-mail, while one, due to logistics and at the request of the director, was completed in person in an interview-style situation using precisely the same questions. From the answers provided in the questionnaire, the method of purposeful sampling was used in order to select two case studies for further in-depth research. This method of selection utilised the system of purposeful sampling which involves selecting information-rich cases for further in-depth study. Patton described information-rich cases as "those from which one can learn a great deal about issues of central importance to the purpose of the research..., ${ }^{, 78}$ Based upon the answers provided in the questionnaire, the Gus Fisher Gallery and the George Fraser Gallery at the University of Auckland were selected as the

\footnotetext{
${ }^{75}$ Patton, Qualitative Research and Evaluation Methods, 306.

${ }^{76}$ Ibid., 21.

${ }^{77}$ Ibid.

${ }^{78}$ Ibid., 46, 230.
} 
subjects of the two case studies. ${ }^{79}$ The chosen galleries were approached to see whether they wished to participate further in the study, and both organisations gave their consent.

Subsequently, a series of interviews were undertaken and these consisted of an approximately one-hour long interview with both the director of the Gus Fisher Gallery and the gallery coordinator of the George Fraser Gallery; a one-hour interview with an Auckland University staff member; and two separate thirty-minute interviews with a Auckland University postgraduate Fine Arts student and an Art History Honours student. Due to time constraints and logistical obstacles interviews via e-mail were also conducted with an undergraduate Fine Arts student and a managerial faculty member from the National Institution of Creative Arts and Industries.

In these interviews, both the standardised open-ended and informal conversation interview approaches were utilised. It was decided to combine these two interview methods as the standard open-ended technique allowed the same carefully and fully worded questions to be asked in each interview. However, the informal conversational approach provided the freedom to explore, probe, and ask unplanned questions in response to the interviewees' answers.

In-depth interviewing is a prominent method in qualitative research and involves asking participants open-ended questions in order to encourage them to reveal their experiences, perceptions, opinions, feelings, and knowledge ${ }^{80}$ Steinar Kvale describes qualitative interviews as "a construction site of knowledge," where the interviewer and the interviewee discuss "a theme of mutual interest." ${ }^{\prime 1}$ This method, therefore, provided me with a large quantity of information in a relative short amount of time. The limitation of interview data, however, can include distorted responses as a result of personal bias, anger, anxiety, politics, or a simple lack of awareness. An interviewee's inability to recall can also influence interview data, along with providing self-serving responses. ${ }^{82}$ I was aware of the limitations of this form of data collection and gave considerable consideration to these issues whilst analysing the data and formulating conclusions.

\footnotetext{
${ }^{79}$ The rationale for this selection is explained in Chapter Two.

${ }^{80}$ Patton, Qualitative Research and Evaluation Methods, 4.

${ }^{81}$ Steinar Kvale, An Introduction to Qualitative Research Interviewing (Thousand Oaks, CA: Sage, 1996), 2, quoted in Marshall and Rossman, Designing Qualitative Research, 142.

${ }^{82}$ Ibid., 145; and Patton, Qualitative Research and Evaluation Methods, 306.
} 
In association with interviews, site visits and other observations were also undertaken. Patton defines observation as "fieldwork descriptions of activities, behaviours, actions, conversations, interpersonal interactions, organisation of community processes, or any other observable human experience." ${ }^{83}$ In this study the method of observation was utilised in specific situations. Firstly, site visits were conducted in order to interview the Gallery and University staff. While there, I observed factors such as the location of the Gallery within the University, signage, and advertising of the Gallery around the University campus, as well as other exhibition spaces located within the University premises.

As part of this qualitative research study, I also carried out document analysis. The term "documents" can encompass a large variety of texts such as official publications, memorabilia, artistic works, and personal diaries. Despite what form the documentation may take, this type of data can yield valuable information about an individual, programme, or organisation, including their values, beliefs, goals, and history. I examined the exhibitions and public programmes archives of both the Gus Fisher Gallery and the George Fraser Gallery from approximately January 2008 until December 2014. This was done through online archives as well as through publications and Gallery documents. However, like all forms of data collection, documents and records also have limitations. For instance the documentation may be incomplete, inaccurate, or biased and consequently may skew the data. Consideration was given to this issue, and only exhibitions with credible and complete detail were selected as examples in this research project.

In order to ensure that my findings were credible, I attempted to adhere to the principles put forward by Yvonna Lincoln and Egon Guba in their seminal text on qualitative methodologies, Naturalistic Inquiry. ${ }^{84}$ In order to verify credibility and validity, Lincoln and Guba urge qualitative researchers to employ four procedures: prolonged engagement (i.e. spend a long period of time in the study's setting); member checks (i.e. share data and interpretations with participants); triangulation (i.e. gather data from multiple sources using multiple methods); and peer debriefing (i.e. discuss finding with critical colleagues). ${ }^{85}$ Although other researchers have expanded upon these principals in recent decades, the four

\footnotetext{
${ }^{83}$ Patton, Qualitative Research and Evaluation Methods, 4.

${ }^{84}$ Yvonna S. Lincoln and Egon G. Guba, Naturalistic Inquiry (Beverley Hills, CA: Sage, 1985), cited in Marshall and Rossman, Designing Qualitative Research, 39-40.

${ }^{85}$ Ibid., 40.
} 
procedures presented by Lincoln and Guba are still considered central to establishing credibility and validity in qualitative research. ${ }^{86}$ I have attempted to utilise triangulation by employing the methods of observation, interviews, and document analysis. I have also discussed my finding with my dissertation supervisors as well as my fellow Museum and Heritage Studies students in order to receive their critical feedback. Once my dissertation is completed, I will also provide participants with a copy of my finding and conclusions should they wish to view it.

This thesis consists of three main chapters. The first chapter provides a general overview of all of the six university art galleries currently operating in Aotearoa New Zealand. The chapter then goes on to discuss the two distinctive types of university art galleries and examines the advantages and challenges that face these organisations. Chapter two presents an in-depth case study of the George Fraser Gallery at the University of Auckland and examines the ways in which this gallery is utilised as a teaching tool and resource as well as the ways in which it assists its parent organisation to achieve its strategic and academic objectives. The final chapter examines the case study of the Gus Fisher Gallery, also at the University of Auckland. This segment follows a similar structure to the previous case study by examining how the University utilises the Gallery as a pedagogical instrument as well as the ways in which this organisation serves as a mechanism through which the University can achieve its overarching ambitions. These chapters are then followed by a conclusion which recaps the findings presented in the previous sections and discusses the prevalent issues concerning university art galleries within this country.

\footnotetext{
${ }^{86}$ Ibid., 40-41.
} 


\section{Chapter One: An Overview of University Art Galleries in New Zealand}

As previously stated there are seven university art galleries currently operating within Aotearoa New Zealand. This chapter will provide a brief outline of all of these organisations and will then present the notion that there are two distinctive types of university art galleries within this country. The differing characteristics and qualities of these two kinds of organisations will be analysed and followed by a discussion of the advantages and challenges that university art galleries face within New Zealand's current situation.

\section{The Adam Art Gallery Te Pātaka Toi}

The Adam Art Gallery Te Pātaka Toi at Victoria University of Wellington is New Zealand's first purpose-built university art gallery. The concept of a university art gallery was first proposed to the University by the Head of Art History, Jenny Harper, in April 1995. However, it was not until 1997 when Wellington philanthropists, Denis and Verna Adam, donated almost half of the $\$ 2.2$ million cost of the project that the venture truly came into fruition. ${ }^{1}$

Despite the Adams' momentous act of generosity, the establishment of the Adam Art Gallery was marred by controversy. Although the Adam bequest had financed a large portion of the project, the University was left to raise the remaining cost of the Gallery. The University undertook a substantial fundraising effort, but was nonetheless confronted by a shortfall of almost $\$ 80,000$. Subsequently, the University made the decision to fill this deficit by selling an artwork from the Victoria University of Wellington Art Collection. After much consideration and consultation, the University chose to sell Storm Warning (1980-81), an artwork by arguably New Zealand's most well-known artist, Colin McCahon. ${ }^{2}$

This decision sent shockwaves through the arts community which were later amplified when a letter written by McCahon was discovered in the University's archives outlining the artist's

\footnotetext{
${ }^{1}$ William McAloon, "Victoria's Art - The Story of a University Collection," in Victoria's Art: A University Collection, ed. William McAloon (Wellington: The Adam Art Gallery Te Pātaka Toi, 2005), 21.

${ }^{2}$ Ibid., 22.
} 
intention to donate the painting to the University. ${ }^{3}$ In this letter McCahon explicitly stated that "it is a public work and I don't want it disappearing into a private collection." Despite the controversy surrounding this decision, the University remained staunch, and on 4 May 1999 it was confirmed that the painting had been sold to an anonymous private collector. The funds received from the sale of the artwork not only met the Gallery's shortfall, but also allowed the University to establish a trust to fund future acquisitions. ${ }^{5}$

When speaking to Michael Houlahan in 1997, Harper explained that the Adam Art Gallery had a multi-fold purpose: it would be responsible for caring for the University Art Collection; curating exhibitions using that collection and other loaned artworks; hosting touring exhibitions, and serving as an educational space. Harper stated that there were "two tiers" of proposed use by the University: "One is intended to be the art history students, but secondly we also see the gallery as being multi-disciplinary, and working with other departments."6 This objective was further expressed by the inaugural director of the Gallery, Zara Stanhope, who stated:

The gallery has a broad vision about relating to the public and community as well as Victoria students and staff. While the focus is on historical and contemporary art, visitors will see exhibitions that relate to architecture, theatre, performance, and fields beyond the humanities. ${ }^{7}$

The current vision and mission of the Adam Art gallery states that the Gallery is a "researchled" institution which, ${ }^{8}$

... initiates, produces and presents a highly-regarded programme of exhibitions, events and publications; manages and develops the Victoria University of Wellington Art Collection, and provides a vital platform for critical thinking across media, disciplines, cultures and contexts. Using art and its presentation as a tool for analysis, it contributes to the production of new knowledge and creates

\footnotetext{
${ }^{3}$ For more information about the controversy regarding the sale of McCahon's artwork, see: Simon Jones, "McCahon Treasure for Sale," Sunday Star Times, 18 April, 1999; Sarah Catherall, "Storm Warning for Gallery Opening," Sunday Star Times, 19 September, 1999; Josie McNaught, "Staying put for Art's Sake," The Dominion, 22 September, 1999; and Gregory O'Brien, "Somebody Say Something," Sport 23 (November, 1999): 9-38.

${ }^{4}$ Letter from Colin McCahon to Victoria University of Wellington, 2 June, 1981, Adam Art Gallery files:

VUWcollection/Artists/McCahon, cited in McAloon, "Victoria's Art," in Victoria 's Art, 22.

${ }^{5}$ Ibid., 22.

${ }^{6}$ Mike Houlahan, "Showing a Burgeoning Collection," Evening Post, 3 November, 1997.

${ }^{7}$ McNaught, "Staying put for Art's Sake."

${ }^{8}$ The Adam Art Gallery, "Research - About" (accessed 3 July, 2014).
} 
opportunities for learning, for the benefit of staff, students and the wider community. 9

The Gallery's current ongoing research project, entitled 'Sound Check,' involves the investigation and exploration of the intersections between sound and art, a previously unexamined subject within the history of music and art in New Zealand. According to the Gallery, this complements the exhibition programme as performances can take place in the architecturally-designed, three-storied gallery during exhibition changeovers and can also occur beyond the confines of the gallery space. As a university art gallery, the Adam Art Gallery states that it is

... dedicated to advancing critical debate about the visual arts ... [and] is particularly concerned to extend discussion of the visual arts by exploring their intersections with other disciplines and by constructing informed historical frameworks for new thinking. ${ }^{10}$

The Gallery is staffed by a team of five people which includes a director, curator, gallery administrator, collections officer, and exhibitions officer. Interestingly, the Gallery also has a position entitled the "Adam Art Gallery Curator-At-Large", a role which offers an overseasbased curator the opportunity to provide the Gallery with "on-the-spot insights into the arts scene" while allowing the Adam Art Gallery to "extend its reach internationally." 11 The Gallery staff are assisted by an advisory board consisting of six individuals from both the University and the wider cultural community. ${ }^{12}$ The Gallery also runs an annual volunteer programme, consisting of approximately 60 students who are involved in assisting with the daily supervision of the Gallery and in the coordination of projects and events. ${ }^{13}$

In keeping with Jenny Harper's ambitions for the organisation, the Adam Art Gallery provides a number of services in order to provide a platform for teaching and research. This includes not only a series of evolving exhibitions and public programmes, but also education tours, the administering of the New Zealand Art Archive in conjunction with the Art History department, and academic support, which offers staff and students the opportunity of using

\footnotetext{
9 The Adam Art Gallery, "About” (accessed 22 June, 2014).

${ }^{10}$ The Adam Art Gallery, "Current Research" (accessed 3 July, 2014).

${ }^{11}$ The Adam Art Gallery, "Staff and Advisory Board” (accessed 3 July, 2014).

12 Ibid.

${ }^{13}$ Christina Barton (Director, the Adam Art Gallery) in discussion with the author, 4 August, 2014; Ibid.
} 
the Gallery and the Victoria University of Wellington Art Collection in their academic pursuits. $^{14}$

\section{Calder \& Lawson Gallery}

Although the University of Waikato does not currently offer any programmes in the areas of Art History or Fine Arts, the University administers the Calder \& Lawson Gallery, which is located in the Gallagher Academy of Performing Arts Te Whare Tapere. According to Stephanie Chalmers, the current curator of the University of Waikato Art Collection, the Gallery "space is a corridor - literally - not a defined destination." 15 Yet, despite its small size, the Gallery stages a series of exhibitions that focus on a range of contemporary art from some of New Zealand's best-known artists.

The exhibitions that are held in the Gallery are complemented by a range of contemporary New Zealand artworks loaned from the James Wallace Art Trust which are displayed in other spaces throughout the Academy building. The Wallace Arts Trust runs a loan programme that enables a wide range of public institutions to borrow artworks from its collection, which consists of approximately 6,500 pieces. Alongside the University of Waikato, the Trust has also lent artworks to other tertiary institutions such as the University of Auckland, Auckland University of Technology, and Massey University. ${ }^{16}$

The fact that the University of Waikato no longer possesses an Art History department or a College of Art begs the question as to why the University has concerned itself with establishing an art gallery. According to Chalmers, the University knows that "an art collection of high quality contributes to the institution's intellectual environment, and is a source of pleasure and inspiration to its students, staff, visitors and wider community."17 Consequently, the Gallery acts as a starting point for student and staff engagement with visual art and exhibits the University's collection as a means of adding to the intellectual conversation that occurs within the academic environment of the University. ${ }^{18}$

\footnotetext{
14 The Adam Art Gallery, "Services" (accessed 3 July, 2014).

${ }^{15}$ Stephanie Chalmers (Curator, University of Waikato Art Collection), in e-mail correspondence with the author, 22 July, 2014.

${ }^{16}$ Wallace Arts Trust, "The Wallace Arts Trust Loan Programme” (accessed 27 June, 2014).

${ }^{17}$ Stephanie Chalmers, 50 Year Mix: A Selection of Works from the University of Waikato Art Collection

(Hamilton: The University of Waikato, 2014), n.p.

${ }^{18}$ Chalmers, correspondence.
} 


\section{The Engine Room}

The Engine Room is the art gallery for the Whiti o Rehua School of Art at Massey University and is located on the Wellington campus. The Gallery is administered by the School of Art which, along with the School of Design Ngā Pae Māhutonga, is a department of the College of Creative Arts Toi Rauwharangi. According to the Head of School, Associate Professor Heather Galbraith:

Art is fundamental to the way we see, experience and understand the world. The richness of our culture relies on fostering artists, curators, writers, designers, producers and critics to do great work and to share it within the country and on the international stage. ${ }^{19}$

Subsequently, the purpose of the Engine Room is to facilitate this ambition by offering "a site for exhibition, performance, debate and discussion around key issues in contemporary art."20

The Engine Room's exhibition programme consists of a frequently changing series of shows which number between 10 to 12 per year. These exhibitions include work by both students and staff as well as artwork by national and international contemporary artists. Currently, the exhibition programme allows for one show by Bachelor of Fine Arts students, another by Fine Arts students specialising in photography, and a Fine Arts postgraduate student exhibition. The Engine Room is also utilised for $\mathrm{PhD}$ examinations. ${ }^{21}$

Every year the Gallery invites applications from students for the twelve-month paid position of the Engine Room assistant, and currently a second year Master of Fine Arts student is carrying out this role. The Gallery assistant is supported by a cohort of volunteers who are required to supervise the Gallery during opening hours, work as artist assistants for visiting artists, and help with larger projects and hosting artists. ${ }^{22}$

In October 2014, the School of Art at Massey University in conjunction with the Wellington City Council and Wellington Waterfront Ltd. have launched Te Whare Hēra (The House of

\footnotetext{
${ }^{19}$ Heather Galbraith, "Whiti o Rehua - the School of Art," College of Creative Arts Toi Rauwharangi, Massey University (accessed 24 November, 2014).

${ }^{20}$ Heather Galbraith (Head of Whiti o Rehua - the School of Art) in e-mail correspondence with the author, 6 July, 2014.

${ }^{21}$ Ibid.

${ }^{22}$ Ibid.
} 
the Sails), a contemporary international artist residency located on Clyde Quay Wharf. ${ }^{23}$ According to Galbraith, the activities of the Engine Room are often integrated with initiatives such as Te Whare Hēra and other enterprises like the Pasifika Artist-in-residence Programme and Toioho ki Apiti Māori Visual Arts Programme, as well as partnerships with Auckland University of Technology, the Royal Melbourne Institute of Technology (RMIT), and other tertiary providers. ${ }^{24}$

\section{The George Fraser Gallery}

The George Fraser Gallery is the student-run exhibition space for the Elam School of Fine Arts at the University of Auckland, offering students the opportunity to showcase their artwork in a professional and public context. The Gallery is located in the Frank Sargeson Centre, a two-storeyed brick building that sits on the eastern edge of Albert Park, opposite the University. According to Graeme Lay, in Victorian times the building comprised of stables for the horses that belonged to the wealthy Auckland residents who resided on Princes Street. ${ }^{25}$ However, by the mid-1900s, the stables had declined into a derelict state. The building remained in this condition until 1986 when the writer and historian, Michael King (1945-2004) proposed to convert the stables into accommodation for a New Zealand writers' fellowship to be offered by the Sargeson Trust. Fletcher Building Company renovated the historic building at cost and the new layout comprised a writer's studio and apartment on the top floor and an art gallery beneath. When Sir James Fletcher's art advisor, George Fraser, passed away soon after the building was completed, King and Fletcher decided that the gallery would be named after Fraser and administered by the Sargeson Trust, providing an exhibition space for emerging avant-garde artists and their artwork. In 1993 the Sargeson Trust offered to lease the George Fraser Gallery to the Elam School of Fine Arts as an exhibition space for students.

Due to the nature of the Gallery as a student-run artist space, the daily operations of the George Fraser Gallery are managed by a Fine Arts student who is appointed to the role of gallery co-ordinator. Currently, this position is carried out by Jaimee Stockman-Young, a

\footnotetext{
${ }^{23}$ College of Creative Arts Toi Rauwharangi, "New International Arts Residency has Contemporary Focus," Massey University (accessed 24 November, 2014).

${ }^{24}$ Galbraith, correspondence.

${ }^{25}$ Graeme Lay, "A Fellowship of the Pen," The New Zealand Herald, 6 April, 2013 (accessed 1 December, 2014).
} 
fourth year Bachelor of Arts Honours student at Elam School of Fine Arts. She is supported by a gallery assistant, who is also a Fine Arts student, as well as a group of first-year student volunteers who assist with installing exhibitions, supervising the Gallery, assisting at openings, and helping with general maintenance. ${ }^{26}$

Alongside the management of the George Fraser Gallery, the gallery co-ordinator is also responsible for the Elam Projectspace Gallery. Similarly to the George Fraser Gallery, this space presents a series of exhibitions and events which primarily focus on presenting artwork produced by Elam undergraduate students. Therefore, the George Fraser Gallery is an exhibition space generally reserved for final year, honours, and postgraduate Fine Arts students, and is often utilised for their end-of-year assessments. ${ }^{27}$

Due to its role as the public showpiece for the Elam School of Fine Arts, the George Fraser Gallery is situated within the National Institute of Creative Arts and Industries (NICAI). This faculty not only encompasses the School of Fine Arts, but also the School of Architecture and Planning, the School of Music, the Dance Studies Programme, and the Centre for Art Studies. As a result of its wide-ranging scope, NICAI places a strong emphasis on creative and innovative inter- and trans-disciplinary collaboration. ${ }^{28}$ This means that the George Fraser Gallery strives to host exhibitions from other disciplines, including an annual showcase of top work by Master of Architecture (Professional) students ${ }^{29}$ as well as other University departments. $^{30}$

\section{The Gus Fisher Gallery}

Along with the George Fraser Gallery and the Elam Projectspace Gallery, the University of Auckland also administers the Gus Fisher Gallery. The Gallery is located within the historic Kenneth Myers Centre positioned on Shortland Street in Auckland's central business district. In addition to the Gallery, the Centre also accommodates facilities for NICAI's Dance,

\footnotetext{
${ }^{26}$ Jaimee Stockman-Young (Gallery Co-ordinator, the George Fraser Gallery) in discussion with the author, 25 September, 2014.

${ }^{27}$ Ibid

${ }^{28}$ NICAI "Our Faculty," the University of Auckland (accessed 12 June, 2014).

${ }^{29}$ For instance '5 Futures: Award-Winning Projects from Recent Graduates' (18-22 March, 2014); 'Auckland and Beyond: Four Future Architects' (26-28 March, 2013); and 'Auckland and Beyond: Four Future Architects 2012' (29-31 March, 2012).

${ }^{30}$ For example the George Fraser Gallery hosted the exhibition 'Argos Aotearoa' (25-29 March, 2014) which was organised in collaboration with the English department of the Faculty of Arts at the University of Auckland.
} 
Music, Film and Television schools. The building is classified by Heritage New Zealand Pouhere Taonga as a Category 1 Historic Building due to its historical significance as the first licensed radio broadcasting station in New Zealand, which accounts for its strikingly unusual fortress-like, Romanesque-style exterior. ${ }^{31}$ The building was gifted to the University of Auckland by the New Zealand businessman, Sir Douglas Myers, who acquired it from Television New Zealand during the sale of state-owned assets in the 1980s. Myers bequeathed the building to the University under the condition that it be refurbished and utilised as a centre for performing arts. As part of the fundraising campaign for the building's restoration, a number of prominent businesspeople from Auckland were approached, including the well-known fashion entrepreneur and art lover, Gurshon (Gus) Fisher (19202010). With his financial support it was decided that the upper floor of the building was to house the professional and international-standard art gallery of the University of Auckland. The Kenneth Myers Centre, named in honour of Sir Douglas Myers's father, opened in 2001 and housed the new School of Creative and Performing Arts (SCAPA). On 3 March 2001, the Gus Fisher Gallery, named after its principal sponsor, launched its first exhibition, 'Bright Paradise,' in association with the $1^{\text {st }}$ Auckland Triennial. ${ }^{32}$

The mission of the Gus Fisher Gallery, which has remained unchanged since its foundation, is "to engage with current issues in the visual arts, promote understanding and foster critical debate through a programme of challenging exhibitions based on active research." ${ }^{, 33}$ In order to achieve this objective, the Gus Fisher Gallery hosts a series of exhibitions and public programmes focussing on contemporary and historical art from New Zealand as well as from overseas. ${ }^{34}$ Due to its position within NICAI, many of the exhibitions are in some way related to the Elam School of Fine Arts or to other University departments such as Art History.

In order to be utilised as a platform for teaching and learning, the Gus Fisher gallery states that it,

... actively fosters creative and academic research, encourages curatorial practice and the development of postgraduate study in the visual arts, and makes a valuable contribution to cultural heritage and museum studies, both at the University and in the wider community. ${ }^{35}$

\footnotetext{
${ }^{31}$ Heritage New Zealand Pouhere Taonga, “Television New Zealand Studios” (accessed 29 December, 2014).

${ }^{32}$ Linda Tyler (Director, Centre for Art Studies) in discussion with the author, 31 August, 2014.

${ }^{33}$ Ibid.

${ }^{34}$ NICAI, "Gus Fisher Gallery,” the University of Auckland (accessed 12 June, 2014).

${ }^{35}$ Ibid.
} 
This purpose is evident in the range of exhibitions that the Gus Fisher Gallery hosts, which include student-curated exhibitions, ${ }^{36}$ showcases of artwork created by Elam staff and students, ${ }^{37}$ and shows presenting the research of academic staff from a variety of different disciplines at the University of Auckland. ${ }^{38}$

The Gallery is staffed by a team of approximately four people which includes a gallery technician, an assistant curator, an administrative assistant, and a director. The current director, Associate Professor Linda Tyler, is also responsible for managing and developing the University of Auckland Art Collection as well as supporting and guiding the student-curated art gallery Window, which consists of both a physical gallery location in the foyer of the University General Library and as an online digital platform. ${ }^{39}$

\section{SoFA Gallery / Ilam Campus Gallery}

The Ilam Campus Gallery is the current exhibiting space for the Ilam School of Fine Arts at the University of Canterbury. According to the University, the goal of its art gallery is, ... to stage a diverse range of arts and cultural programmes through exhibitions, performances and events for the promotion, education and enjoyment of the arts by the University and the wider Canterbury communities. ${ }^{40}$

In 2002, the University strategically expanded the Ilam Campus Gallery and established a small satellite space, called SoFA Gallery, in the Christchurch Arts Centre. According to Joanna Cobley, the purpose of this endeavour was to show the potential of the SoFA Gallery as a "research station" while strengthening "town and gown" relationships by establishing

\footnotetext{
${ }^{36}$ For example, 'Voicing the Visible: Feminist Art from the University Collection' (9-31 May, 2014) was curated by 18 students from the Art History Honours course, Art Writing and Curatorial Practice.

${ }^{37}$ For instance, 'New Graduate Works' (5-20 December, 2014) displayed work by graduating students from Elam School of Fine Arts and was curated by Tim Wagg, who is an Elam graduate. Associate Professor Nuala Gregory from Elam School of Fine Arts presented her work in the exhibition 'Exploded View' (4 June - 17 July, 2010).

${ }^{38}$ Such as 'Collateral: Printmaking as Social Commentary' (1 July - 20 August, 2011) curated by Professor Elizabeth Rankin; and 'A Different View: Artists Address Pornography' (23 August - 12 October, 2013) was co-curated by Centre for Art Studies Associate Professor Linda Tyler, and Psychology Associate Professors Virginia Braun and Nicola Gavey.

${ }^{39}$ For more information see: NICAI, "The University of Auckland Art Collection," the University of Auckland (accessed 12 June, 2014); and Window, “About," the University of Auckland (accessed 2 November, 2014).

${ }^{40}$ Ilam School of Fine Arts, "Exhibitions," the University of Canterbury (accessed 11 July, 2014).
} 
external partnerships with industry and the community. ${ }^{41}$ Consequently, SoFA Gallery became a vehicle to "market" the Ilam School of Fine Arts within Christchurch's arts community and present itself as one of the country's top fine arts schools. ${ }^{42}$ The consultant curator, Ewen McDonald said that the University viewed that Gallery "as being like one of the university's field stations or outposts. This is the School of Fine Arts' outpost where students can be experimental. It's also about bringing the university and arts school into the city." ${ }^{43}$ Kate Darrow, the inaugural manager of the Gallery, also emphasised the value of the Gallery's volunteer programme which provided a variety of students, particularly Art History students, with “... a good learning experience by arranging artists” talks and workshops on gallery procedures such as handling and installing artworks."

However, in 2004, the existence of SoFA Gallery at the Arts Centre came under threat due to the University's widely publicised financial hardship. The Gallery's funding was significantly cut and it was decided that the Gallery would operate on a month-by-month basis. ${ }^{45}$ According to Garth Galloway, a supporter of SoFA Gallery, this decision was made because "the powers that be at the University don't really understand the significance of the Gallery or appreciate all the good things it operates for the University and for the town."46 The Gallery, however, devised an innovative plan of raising funds by holding a sales exhibition of etching prints by some of New Zealand's most well known contemporary artists. According to the curator, Simon Ogden, this show was "... an attempt to help the gallery continue to run exhibitions. It was a project initiated for that reason. All the artists approached to help could see the validity and need. They responded with huge generosity."

In 2011, the Arts Centre complex was devastated by a 6.3 magnitude earthquake which struck Christchurch on the 22 February. Consequently, the SoFA Gallery at the Arts Centre is now closed for the foreseeable future and the exhibition programme is solely located at the Ilam Campus Gallery. ${ }^{48}$ Despite this major setback, the Gallery continues to present a series of

\footnotetext{
${ }^{41}$ Joanna Cobley, "Art Spaces as Research Stations: Investigating SoFA," Te Ara Journal of Museums Aotearoa 29, no. 2 (November, 2004): 22.

${ }^{42}$ Ibid., 24.

43 Anna Dunvar, "Students' Showcase," The Press, 24 April, 2002.

${ }^{44}$ Ibid.

${ }^{45}$ Frontseat, episode 28, first broadcasted in 2004 by TVNZ, produced by Gemma Gracewood.

${ }^{46}$ Ibid.

${ }^{47}$ Christopher Moore, "Etching the Future," The Press, 8 December, 2004.

${ }^{48}$ Ilam School of Fine Arts, "About SoFA," the University of Canterbury (accessed 11 July, 2014).
} 
exhibitions which are curated by students and present the artwork of current Fine Arts students alongside shows of some of New Zealand's most recognised artists.

In conjunction with the Ilam Campus Gallery, Ilam School of Fine Arts also administers the Casting Room, which is a small installation-based exhibition space showcasing student artwork and curated by the sculpture department. ${ }^{49}$

\section{St Paul St Gallery}

St Paul St Gallery was established in 2004 and is the art gallery for the School of Art and Design at the Auckland University of Technology. The Gallery consists of a suite of purposebuilt exhibition spaces which include two galleries, a new media project area, a window gallery, and an outdoor projection wall. The Gallery is primarily focussed on the development of contemporary art and design and achieves this through a programme of exhibitions, symposia, publications, and events. ${ }^{50}$ The Gallery presents a wide variety of curatorially-driven exhibitions that include one-night events, major group and solo exhibitions, showcases of internationally renowned artists, as well as the presentation of student and staff projects.

The Gallery is staffed by a team of approximately four people which includes a director and curator, an assistant director, a gallery assistant, and a gallery technician. The staff is supported by a team of volunteers as well as a Gallery committee composed of a number of staff members from across the School of Art and Design.

The identity of St Paul St as a university art gallery is central to its overarching mission. In its mission statement, the Gallery states that it "...embraces on the primary instructions for universities in the New Zealand Education Act (1984) that they 'accept a role as critic and conscience of society'."51 Subsequently, the Gallery endeavours to expose the ways in which the visual arts have the capacity to speak critically about society and its issues. ${ }^{52}$

\footnotetext{
${ }^{49}$ The Casting Room (accessed 11 July, 2014).

${ }^{50}$ St Paul St Gallery, “About Us," Auckland University of Technology (accessed 27 June, 2014).

${ }^{51}$ New Zealand Education Act 1989, pt 14, s 162, subs 4a, cl (v), quoted in ibid.

${ }^{52}$ Ibid.
} 


\section{The two types of university art galleries}

When examining the outlines of the university art galleries within New Zealand, it is apparent that there are two distinct types. The first of these is an art gallery that is aligned with a fine arts school, such as the Engine Room, the George Fraser Gallery, and SoFA Gallery/Ilam Campus Gallery. Due to this fact, the main intention of this type of gallery is to showcase the work of Fine Arts students. Usually, these galleries have a high degree of student involvement that can include exhibition content, curation, installation, and management. These galleries are somewhat informal and embody a sense of experimentation that draws from the diverse practice of contemporary Fine Arts students. This type of gallery is heavily utilised within the courses of the Fine Arts programme as spaces in which undergraduate endof-year exhibitions are held or final year and postgraduate assessments take place.

These galleries play a critical role within the early careers of emerging artists as they are often the first space where budding arts students exhibit their work in a public forum. Subsequently, the purpose of this type of gallery is to provide Fine Arts students with early exposure while providing them with "real world" experience and a first-hand insight into the practical workings of the art gallery industry. Yet, unlike the "real world" the university art gallery is a safe environment which nurtures this learning experience and unlike public, commercial, or curatorially-driven university art galleries, it does not demand a highly polished final product.

The second type of university art gallery is distinguished by its curatorially-driven vision and its professionalised and polished delivery of exhibitions and public programmes. Examples of this kind of gallery include the Adam Art Gallery, the Calder and Lawson Gallery, Gus Fisher Gallery, and St Paul St Gallery. Although this type of university art gallery does include student involvement, this is largely limited to volunteer programmes with only a few occasions of student-curated exhibitions which are mostly undertaken by postgraduate art history students. These galleries are formal spaces and are viewed as vehicles for strengthening "town and gown" relationships, to provide the external community with an insight into some of the research endeavours undertaken by academic staff and postgraduate students of the university. 
These galleries also host touring exhibitions that have been developed by both national and international public art galleries. By hosting touring exhibitions that present the artwork of eminent artists from New Zealand and overseas, these university art galleries solidify their position within the national and cultural elite. Thus, these galleries gain an element of prestige, which ultimately adds to that of the university. This is an important factor when considering the increasingly competitive nature of the tertiary sector. An esteemed university art gallery can easily be marketed as an enticing commodity to prospective students and, as Joanna Cobley rightly contends, may assist in "promoting a funkier image to a discerning youth audience." 53

Another element to this type of gallery is that the responsibility of managing and developing the university art collection usually falls within their domain. New Zealand universities have developed their art collections over a number of decades, and previously these collections were left to evolve organically and were not subject to professional collection management practice. The development of university art galleries has meant that these collections now receive professional collection management. ${ }^{54}$ However, these university art galleries do not house the university's collection; instead these collections are characterised by their dispersed nature and are often scattered across multiple campus sites.

The distinction between a student-centric university art gallery aligned with a fine arts school and a curatorially-driven university gallery is evident at the very core of their identities. When asked to describe their organisation in terms of a metaphor or short phrase, studentcentric university art galleries described themselves in more practical yet experimental terms. They used phrases such as a "project space for experimentation and trial in the diverse areas of contemporary fine arts practice," a "test space," an "exhibition space," and a "working model." ${ }^{, 55}$ In contrast the more curatorially-driven art galleries expressed themselves with words that emphasise engagement, including a "gateway to art appreciation" and "a drop-in centre for curious minds." 56 Interestingly, the most common phrase utilised by directors was "platform" and both student-centric and curatorially-driven galleries used this term to describe themselves but with slightly different connotations. The student-centric galleries

\footnotetext{
${ }^{53}$ Cobley, "Art Spaces as Research Stations," 24.

${ }^{54}$ Ibid., 23.

${ }^{55}$ Galbraith, correspondence; and Robin Neate (Lecturer, Ilam School of Fine Arts) in e-mail correspondence with the author, 22 July, 2014.

${ }^{56}$ Chalmers, correspondence; and Associate Professor Linda Tyler in e-mail correspondence with the author, 19 July, 2014.
} 
considered themselves to be a platform because it is "less of a teaching environment and more a stage in which one can gather industry experience from a multitude of different angles." ${ }^{57}$ While the curatorially-driven organisations utilised the term because it embodies the idea that "people come from their own different disciplines and, when they step onto the platform, they are actually in a new space which is our space. ... When you stand on a platform or you occupy a position like that, you are actually engaging a public.. 58

Furthermore, the purpose and overarching mission of these university art galleries is also characterised by this distinction. Student-centric galleries believe that their purpose is one of practical experience and presentation, while curatorially-driven galleries emphasise their potential to provide staff, students, and the wider community with an experience of intellectual encounter. For student-centric galleries their purpose is to "engage the student body in gallery practice, facilitate the development of an artist's/gallerist's career through early publicity and exposure,"59 enabling Fine Arts students to experience a "real world" art gallery situation before embarking upon a professional career within the realms of dealer galleries, artist-run spaces, and public galleries. ${ }^{60}$ This objective differs to that of the curatorially-driven gallery, which emphasises intellectual stimulation and scholarship through engagement with the visual arts. According to one director, curatorially-driven university art galleries have "this luxurious role of offering an independent programme that draws on the research of people here ... but also beyond the University which we believe is of interest and use to the University community and to wider audiences."

\section{Advantages and challenges for New Zealand university art galleries}

As previously discussed, university art galleries occupy an awkward position poised between the two realms of the museum and gallery industry and the university sector. This unique status, therefore, comes with its own set of advantages and challenges. One of these advantages is the position of university art galleries within an institution that preserves and enhances the right of academic freedom. This enables university art galleries "to question and

\footnotetext{
${ }^{57}$ Jaimee Stockman-Young in e-mail correspondence with the author, 1 August, 2014.

${ }^{58}$ Barton, discussion.

${ }^{59}$ Stockman-Young, correspondence.

${ }^{60}$ Neate, correspondence.

${ }^{61}$ Barton, discussion.
} 
test received wisdom, to put forward new ideas and state controversial or unpopular opinions, ${ }^{, 62}$ which subsequently allows university art galleries to exercise a significant amount of independence in the kinds of exhibitions and public programmes they provide. As one director identified, independence provides university art galleries with "the freedom to be exploratory, experimental, provocative, to be comparatively free of constraints dictated by commercial pressure, or censorial imperatives." ${ }^{\prime 63}$ This unique capacity differs from many public art galleries who are governed by boards of trustees or local government and are dependent upon achieving certain key performance indicators in order to receive funding. Thus, New Zealand university art galleries believe that they are in a privileged position because, as stated by one university art gallery director:

... they are protected and nurtured within the context of an institution dedicated to higher learning and to the profound ideals of knowledge production and research. ... [W] $\mathrm{e}$ are in a privileged position of putting thinking and exploration and experimentation ahead of audience numbers, bums on seats, financial requirements to make money. ... [We can] aim to inspire and stimulate and question and challenge, and not simply entertain.",64

Another advantage identified by university art galleries was their proximity to leading researchers who are specialists in a vast array of different disciplines. Accordingly, this enables university art galleries to open up avenues of discussion around the visual arts which may not be available or appropriate for other types of art galleries. As one director mentioned:

I think we are also in a really privileged position because we have all these experts and all these interesting people around us. We can actually use art as a kind of catalyst to engage different disciplines and get people thinking and encourage the kind of inquisitive questioning that is really vital for production of new ideas and new knowledge. Everyone is sort of right on our doorstep, and I think that is a real advantage. ${ }^{65}$

However, alongside those advantages are a number of challenges. As a small unit within a large bureaucratic organisation like a university, art galleries often find themselves overlooked or forgotten. ${ }^{66}$ This factor can be compounded by the fact that university management often does not understand the mission or purpose of university art galleries and are often more focussed upon "valuable" disciplines such as the Sciences, Law, Engineering,

\footnotetext{
${ }^{62}$ New Zealand Education Act 1989, pt 14, s 161, subs 2(a).

${ }^{63}$ Galbraith, correspondence.

${ }^{64}$ Barton, discussion.

65 Ibid.

${ }^{66}$ Ibid.
} 
and Commerce. As one director noted, their biggest challenge is "fitting into the bureaucracy and general nature of an institution like a university which does not always hold creative pursuits as a first priority. $" 67$

The most prevalent challenge faced by New Zealand university art galleries is not being considered "core business" by their parent organisation. This means that university art galleries often find themselves in vulnerable positions during times of financial hardship or budget cuts. Therefore, it became apparent that many, but not all, university art galleries consider it imperative to align themselves with the academic and strategic mission of their parent institution. One gallery director believed that it was vital for university art galleries to do and explained that:

The academic mission [of the University] is to facilitate teaching and learning and to provide leadership in research, and to that end, the [Gallery] is a resource to be deployed to allow learning opportunities and to provide profile opportunities for staff and student research. ${ }^{68}$

Another director stated that their strategic plan follows the model of the University's own strategic plan:

We have taken exactly the same headings and devised objectives that are in line with the University's strategic goals and objectives. Yes, we absolutely align ourselves with the strategic mission of the University. If we didn't we wouldn't be in existence because that notion of our not being core business would make us particularly vulnerable. ${ }^{69}$

Not all university art galleries, however, considered aligning themselves with the academic mission of their university to be a vital endeavour. Many believed that it was their duty to critique entrenched institutional narratives and conventions, such as the universities themselves, ${ }^{70}$ while another stated that "a gallery is an environment for the facilitation/exhibition of contemporary art and as such should be open to any and all discourse, even if that appears not to be directly aligning themselves with the mission of the

\footnotetext{
${ }^{67}$ Stockman-Young, correspondence.

${ }^{68}$ Tyler, correspondence, 19 July, 2014.

${ }^{69}$ Barton, discussion.

${ }^{70}$ Chalmers, correspondence; and Galbraith, correspondence.
} 
institution." ${ }^{, 71}$ For one university art gallery "strict adherence could mean missed opportunities and innovation in cases where that measure may not be the most suitable one.,72

\section{Conclusion: A balancing act}

New Zealand university art galleries are embroiled in a conflicting situation: positioned within a large organisation of a university, an art gallery has to prove its "worth" to the parent organisation. Subsequently, to some degree, there must be some alliance with the academic and strategic mission of its parent organisation. Yet, for many university art galleries this jeopardises what they consider to be their pivotal responsibility - to provide a space in which challenging and provocative discussion of contemporary social issues can take place through the presentation of visual arts. It seems, therefore, that university art galleries must maintain a type of balancing act, to serve as a critic and conscience of society while at the same time proving their value to the university. This dissertation will now go on to select two New Zealand university art galleries and examine the ways in which these organisations contribute to and engage with the academic and strategic agendas of their parent organisations.

\footnotetext{
${ }^{71}$ Stockman-Young, correspondence.

${ }^{72}$ Neate, correspondence.
} 


\section{Chapter Two: The George Fraser Gallery at the University of Auckland}

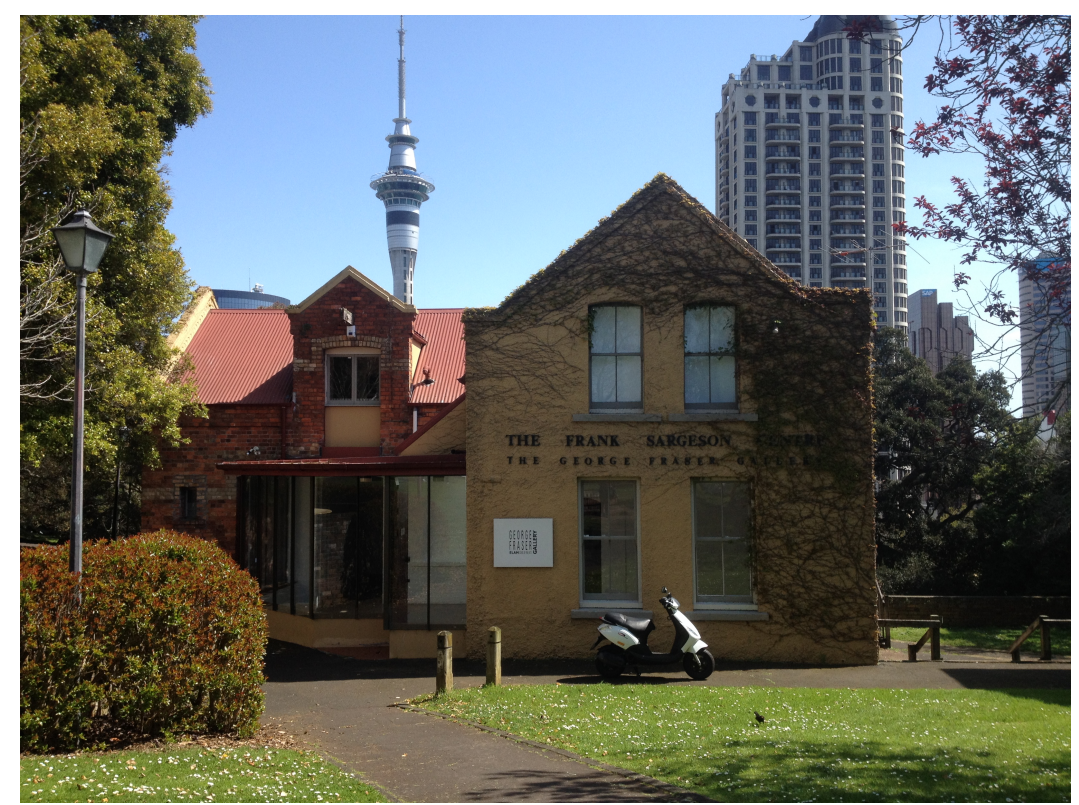

Figure 1: The exterior of the George Fraser Gallery in Albert Park, Auckland. Image credit: Penelope Baines, 2014.

As discussed in the previous chapter, New Zealand university art galleries can be placed into two distinct categories: those that are student-centric and aligned with a Fine Arts school, and those that are more formal, curatorially-driven art galleries. Consequently, for the purposes of this dissertation one of each type of university art gallery has been selected for analysis. The first case study will examine the George Fraser Gallery at the University of Auckland, and the second will consider the Gus Fisher Gallery, also at the University of Auckland. By selecting two art galleries aligned with the same university, there is the obvious disadvantage that this dissertation will be unable to include and examine other universities. However, by selecting two galleries from the same institution, it will be more credible to easily compare and contrast the different ways in which these galleries contribute to and engage with their university communities.

Using the George Fraser Gallery as an example of a student-centric university art gallery aligned with a Fine Arts school, this chapter will examine how and why this gallery has or has not integrated itself with its university constituencies. Consideration will also be given to the manner in which the George Fraser Gallery contributes to the academic and strategic 
objectives of its parent organisation; whether the George Fraser Gallery encourages and nurtures student and staff involvement, and question whether this university art gallery can be considered an example of the emerging Post-Museum.

\section{History and operations}

As previously outlined in Chapter One, The George Fraser Gallery is the student-run public exhibition space for the Elam School of Fine Arts at the University of Auckland. When the Sargeson Trust first established the George Fraser Gallery in 1986, it was not in any way affiliated with the University of Auckland and its purpose was to provide a venue for the public display of avant-garde artwork produced by emerging New Zealand artists. In 1993 the Sargeson Trust offered to lease the George Fraser Gallery to the Elam School of Fine Arts as an exhibition space for students, which preserved the Gallery's avant-garde nature by aligning itself with the contemporary and experimental fine arts practice of the next generation of emerging practitioners. Subsequently, according to the currently Gallery Coordinator, Jaimee Stockman-Young, the George Fraser Gallery has become:

An environment for students to learn not only about the running of a gallery, curation of a gallery, and [gaining] day-to-day work experience... but [it] has also become an environment to test out and learn the manner in which you go about being a real artist. ${ }^{1}$

In this way, the George Fraser Gallery is a "practical test environment" for emerging artists, providing them with the practical skills required in the contemporary creative industries. The George Fraser Gallery is a space which facilitates and nurtures the early public exposure of fledgling artists, but does so within the "safe environment" of the University. ${ }^{2}$

Currently, the George Fraser Gallery is governed by a Proposals Committee which is composed of a technical staff member, an academic staff member, an administrative representative, and a student representative. Their role is to oversee the exhibition proposals submitted by students and other artists at the start of every year. The Committee also has to incorporate internal content within the exhibition programme and this includes showcases by third and fourth year students as well as postgraduate students from the Postgraduate Diploma, Master of Fine Arts, Doctor of Fine Arts, and Doctor of Philosophy programmes.

\footnotetext{
${ }^{1}$ Stockman-Young, discussion.

${ }^{2}$ Ibid.
} 
According to Stockman-Young, the George Fraser Gallery is usually reserved for higherlevel students as the School considers exhibiting at the George Fraser Gallery as part of the professional development process for advancing pupils. ${ }^{3}$ The display of undergraduate work usually takes place at the Elam Projectspace Gallery, an exhibition space located within the main building of the Fine Arts school. Projectspace is administered in conjunction with the George Fraser Gallery and their exhibition programmes are intertwined, enabling the galleries to present an expanded and enhanced dialogue across two sites.

The daily management of both the George Fraser Gallery and Elam Projectspace Gallery are overseen by the Gallery Co-ordinator who is usually a final year or postgraduate Fine Arts student. Currently this role is filled by Jaimee Stockman-Young who is currently in the final year of studying towards a Bachelor of Fine Arts with Honours. The Gallery Co-ordinator reports to the External Relations Manager and the Marketing Manager as well as the School Administrator who assists the Gallery Co-ordinator in the daily organisation of the Gallery. The Gallery Assistant is tasked with supporting the Gallery Co-ordinator, and this role is also filled by a Fine Arts student.

Underpinning this management structure is a volunteer programme consisting of a number of first year students who serve a vital role in the day-to-day operations of the George Fraser Gallery. These volunteers assist in the installation of a variety of exhibitions, supervising the Gallery spaces, assisting during the opening of exhibitions, and helping with the general maintenance of the Gallery. In return, these undergraduate students gain vital practical skills which can then be utilised throughout their studies as well as in their professional careers. According to Stockman-Young, this type of work experience encourages these budding artists to become comfortable and familiar within the environment of a functioning art gallery: "They get to see all sides of the gallery experience. It is a good system, an effective student system rather than it being this ominous separate entity." ${ }^{, 4}$ For one postgraduate Fine Arts student, student involvement within the Gallery serves as a vital learning experience:

It creates an experience; it creates a familiarity with a fine arts space. It teaches them the things you need to do when you finish [studying]. It teaches them you need to do a proposal, you need to be prepared, you need to think about the space,

\footnotetext{
${ }^{3}$ Ibid.

${ }^{4}$ Ibid.
} 
you need to think about the site, marketing, thinking about abstracts, and all that stuff that happens. ... For me it's like an apprenticeship."5

\section{The George Fraser Gallery and its role within the University}

The George Fraser Gallery is situated within the NICAI. As previously explained, this faculty incorporates the School of Architecture and Planning, Elam School of Fine Arts, the School of Music, the Dance Studies Programme, and the Centre for Art Studies. This multi-disciplinary structure means that NICAI places great emphasis on "creative exploration and discovery and on interdisciplinary collaboration across the faculty." ${ }^{\circ}$ Yet, according to Stockman-Young, "the relationship we [the George Fraser Gallery] have between the other students in the different faculties is limited. We are starting to change that now..." ${ }^{, 7}$ However, there are some distinct examples of the George Fraser Gallery being a site of interdisciplinary presentation and exploration. This is evident in the series of architectural exhibitions presented by the Gallery which feature award-winning projects from final year students in the Master of Architecture (Professional) programme. ${ }^{8}$ The display of architectural prototype models, particularly those created by architectural students, are not often the subject of exhibitions within the context of an art gallery. But because the George Fraser Gallery is a university art gallery connected to a broad creative faculty, it can act as a public showpiece for the presentation of student work from a variety of disciplines. It also enables the wider community to obtain an insight into the research and intellectual pursuits of the upcoming generation of creative professionals.

Other disciplinary examples include a public programme event entitled 'Resonate' (16 July 2014) which involve a series of vocal performance by musicians and artists. Due to the solid brick construction of the historic building, the George Fraser Gallery possesses excellent acoustics which enable sound to resonate intensely throughout the space. ${ }^{9}$ A postgraduate Fine Arts student identified 'Resonate' as one of the most memorable events that the George Fraser Gallery has hosted:

\footnotetext{
${ }^{5}$ Auckland University Postgraduate Fine Arts Student, in discussion with the author, 26 September, 2014.

${ }^{6}$ NICAI, "Our Faculty," the University of Auckland (accessed 12 June, 2014).

${ }^{7}$ Stockman-Young, discussion.

${ }^{8}$ Exhibitions include: '5 Futures: Award-Winning Projects from Recent Graduates' (18 - 22 March, 2014);

'Auckland and Beyond: Four Future Architects' (16 - 28 March, 2013); 'Auckland and Beyond: Four Future Architects 2012' (29 - 21 March, 2012); and 'Auckland and Beyond: Four Future Architects' (3 -12 March, 2011).

${ }^{9}$ Stockman-Young, discussion.
} 
It was something out of the notion of an art gallery... It was really enjoyable so there was a lot of participation from the crowd where they were humming and singing along as well. It was pretty awesome. ${ }^{10}$

According to Stockman-Young, the George Fraser Gallery has not previously had an active relationship with the Music and Dance departments of NICAI, however, 'Resonate' showed how successful a collaboration between these entities could be. Subsequently, StockmanYoung hopes to extend the Gallery's exhibitions programme in order to “...include dance and music more, and really try to have it [the George Fraser Gallery] as a cross space."11

Similarly, 'Argos Aotearoa' (25 - 29 March 2014) was an exhibition held in conjunction with the inaugural publication of a new journal of the same name. Argos Aotearoa is an online journal which focuses upon the issues of politics, people and place. ${ }^{12}$ Its first issue was entitled The University Beside Itself and probed the nature of the university as an institution. In light of this theme, all Auckland University students and staff as well as the general public were asked to express their views of the University "by leaving responses in or on the gallery" and were given the opportunity to write their opinions and thoughts upon the crisp white walls of the Gallery. ${ }^{13}$ These responses were accompanied by artworks by Kelley Malone and Makyla Curtis, Alex Jespersen, Pritika Lal, and the art collective Afakasi Baby. The exhibition possessed strong links with the English department at Auckland University, as three of the contributors to Argos Aotearoa were members of the faculty's teaching staff. Tutorials for the English paper 'Introduction to Creative Writing' were held in the Gallery, during which students were encouraged to contribute and express their responses to the exhibition. ${ }^{14}$

In their examinations of university art museums and galleries, Janet Marstine and Lyndel King contend that university art galleries are conducive environments for institutional critique because "they operate in a climate where the questioning of authority is encouraged." 15 "Argos Aotearoa' is an excellent example of the way in which university art galleries can assist the university in fulfilling its role as "a critic and conscience of society" by staging "radical" and

\footnotetext{
${ }_{11}^{10}$ Auckland University postgraduate Fine Arts student, discussion.

${ }^{11}$ Stockman-Young, discussion.

${ }^{12}$ Argos Aotearoa was founded in 2013 by Miri Davidson, Sean Sturm, Stephen Turner, Henry Babbage, and Anna Boswell.

${ }^{13}$ NICAI, "Argos Aotearoa," the University of Auckland (accessed 28 October, 2014).

${ }^{14}$ Carm Lau, "You're Allowed to Write on Walls if You're an Adult," Writing Cradle (blog) (accessed 3 December, 2014).

${ }^{15}$ King and Marstine, "The Role of the University Art Museum and Gallery," 22-25.
} 
"messy" student-driven exhibitions that encourage "institutional reflexivity."16 By enabling staff, students, and the public to write their opinions and experiences of the university upon the walls of the Gallery, 'Argos Aotearoa' enacted Nick Prior's concept of “institutional reflexivity" which involves "a process of self-examination through which the institution comes to know itself better, questioning its own auspices and social function." ${ }^{17}$ Therefore, this exhibition shows that university art galleries not only assist the university in fulfilling its role as "a critic and conscience of society," but also assist the university in critiquing its own institutional nature. Furthermore, this exhibition aligns with the values of the University of Auckland which includes the commitment to:

Creating a diverse, collegial scholarly community in which individuals are valued and respected; academic freedom is exercised with intellectual rigour and high ethical standards; and critical enquiry is encouraged. ${ }^{18}$

\section{The George Fraser Gallery and its role for the University}

Over the past decade, the University of Auckland has placed greater emphasis upon its location within an increasingly multicultural city, especially with regards to the growing Māori, Pacific Island, and Asian communities. This is evident in The University of Auckland Charter 2003 as well as The University of Auckland Strategic Plan 2013-2020 which identified the importance of forming relationships with these communities:

The University's location in Auckland, the largest Pacific city in the world, both necessitates and provides opportunities for a particular relationship with Pacific peoples. The strengthening and deepening of relationships, which will contribute further to the intellectual, social, economic and cultural advancement of Pacific peoples, is an important component of the University's engagement with its communities. The fast-growing Asian populations also contribute to the diversity and vibrancy of the University and Auckland, and are becoming an increasingly important component of the University's academic life. ${ }^{19}$

This strategic objective is evident in the exhibition history of the George Fraser Gallery. Between 20 and 30 August this year, Let's Talk Art, a collective of international students at Elam School of Fine Arts, curated and showcased their work in an exhibition entitled, 'So

\footnotetext{
${ }^{16}$ Marstine, "What a Mess!," 303.

${ }^{17}$ Prior, "Having One Tate and Eating It," 67.

${ }^{18}$ The University of Auckland, The University of Auckland Strategic Plan 2013-2020 (Auckland: The University of Auckland, 20 August, 2012), 3 (accessed 25 August, 2014).

${ }^{19}$ The University of Auckland, The University of Auckland Strategic Plan 2013-2020, 14. Also see: The University of Auckland, "The University of Auckland Charter 2003," sections VI and VII (accessed 17 November, 2014).
} 
Where's Home?'. Let's Talk Art “is a platform for exchange and learning” for international students and students who are recent immigrants or dual residents and their group exhibitions often examine the concepts of home, place and belonging. ${ }^{20}$

Preceding this exhibition, the George Fraser Gallery hosted 'Whakaahua|Portrait (5 -15 August 2014), a showcase of work created by Māori and Pacific Island Fine Arts students who participate in the Tuākana mentoring programme. ${ }^{21}$ This exhibition featured photography, painting, sculpture, hybrid contemporary-traditional Polynesian craft, video, and installation artworks produced by students from a variety of year groups which reflected on the fundamental aspects needed to create a successful portrait in contemporary art practice. ${ }^{22}$

In 2008 and 2009 the George Fraser Gallery also hosted two other similar exhibitions. The first of these was entitled 'The Conch is Calling' which was held in conjunction with Artstation (now known as Studio One Toi Tū) between 30 October and 8 November 2008. This was the first exhibition curated by Pacific Island and Māori artists who were participants in the Tuākana programme. According to Nuala Gregory, the Head of Elam Fine Arts School, this exhibition presented these students with "a chance to showcase their work to the public and [it] provides an important link between tertiary studies and the art world." ${ }^{23}$ Like 'Whakaahua|Portrait' this exhibition showcased a variety of media including photography, painting, sculpture, moving image, and multi-media. In March of the following year, the George Fraser Gallery hosted 'The New Neophytes' (4 -14 March 2009) which again presented works by Tuākana students at Elam School of Fine Arts as well as recent graduates. The name of this exhibition expressed the increasing cultural diversity present within the University of Auckland as well as the wider community:

Neophyte is a metonym for a new nameless generation, neither New Zealandimmigrants nor New Zealand natives, who occupy a neither-here-nor-there site. With many New Zealanders identifying with two or more ethnicities The New Neophyte presents the changing face of our communities. ${ }^{24}$

\footnotetext{
${ }^{20}$ NICAI, "So Where's Home?," the University of Auckland (accessed 17 August, 2014); and NICAI, "Let's Talk Art (for Elam Students)," the University of Auckland (accessed 7 December, 2014).

${ }^{21}$ NICAI, "Tuākana Programme," the University of Auckland (accessed 7 December, 2014).

${ }^{22}$ NICAI, "Whakaahua|Portrait," the University of Auckland (accessed 17 August, 2014).

${ }^{23}$ NICAI, "The Conch is Calling," the University of Auckland (accessed 31 October, 2014).

${ }^{24}$ NICAI, "The New Neophytes," the University of Auckland (accessed 31 October, 2014).
} 
Furthermore, between 31 May and 2 June 2012 the George Fraser Gallery presented Line: Breadthless Length, an exhibition showcasing the work of three artists of Asian descent, Ling Wei Chiang, Philip Tse, and Zi Xuan Guo. This showcase explored the experience of these three artists who find themselves "standing on a line between East and West." 25 The exhibition examined the notion of cultural integration between the East and West through installation and performance art in conjunction with an open studio during the afternoons of the exhibition period.

These exhibitions demonstrate how the George Fraser Gallery is a hub for the public presentation of art produced by the University's multicultural student body. By presenting their work in the public forum of a university art gallery, this space also acts as a social space which can facilitate engagement with the different cultural communities of both the student population, and the wider community. According to one postgraduate Fine Arts student, by staging these kinds of exhibitions the university art gallery can become "a hub, a place to meet, to expose, to advertise, to introduce, to socialise." ${ }^{26}$ Subsequently, the George Fraser Gallery proves itself to be a vehicle through which the University can achieve its strategic goals of developing relationships with the increasingly cultural communities within Auckland.

As well as forging relationships with multicultural groups, the George Fraser Gallery can also assist in developing rapport with the wider arts community. This is evident in the George Fraser Gallery's participation within larger arts festivals staged in Auckland. For example, the Gallery has been an exhibition partner in the last three Auckland Triennials. Most recently, between May and August 2013, the Gallery hosted the exhibition 'Calligraphy and Scratching Leading to the Same Thing' by the Yangjiang Group as part of the $5^{\text {th }}$ Auckland Triennial. ${ }^{27}$ Furthermore, for the past two years, the George Fraser Gallery has also been involved in Auckland Festival of Photography, presenting 'Auschwitz Revisited: by Bronek Kozka' in 2014, ${ }^{28}$ and 'Anxious Production: Disrupting a Functionary Bond' in 2013, which presented

\footnotetext{
${ }^{25}$ NICAI, "Line: Breadthless Length,” the University of Auckland (accessed 30 October, 2014).

${ }^{26}$ Auckland University postgraduate Fine Arts student, discussion.

${ }^{27}$ NICAI, "Yangjiang Group, Shi Tu Tong Gui," the University of Auckland (accessed 28 October, 2014); and The $5^{\text {th }}$ Auckland Triennial, "Yangjiang Group" (accessed 8 December, 2014).

${ }^{28}$ NICAI, “Auschwitz Revisited: by Bronek Kozka," the University of Auckland (accessed 17 August, 2014); and The Auckland Festival of Photography, "Bronek Kozka - Auschwitz Revisited" (accessed 8 December, 2014).
} 
the photographic and sculptural works of two recent Elam graduates, Andrew Kennedy and Vito Trupinic. $^{29}$

By participating in these large-scale arts festivals, the George Fraser Gallery strengthens its ties with the wider arts community. In doing so, the Gallery raises it public profile, positioning itself at the forefront of the contemporary art scene within New Zealand. This ultimately enables the Gallery to provide its students with a credible and highly regarded exhibition space to present their work to the public. This helps to achieve the Gallery's mission to "facilitate the development of an artist's/gallerist's career through early publicity and exposure and create a bridge between art students and the wider community." 30

This mission is further enhanced when the George Fraser Gallery acts as a showpiece for the University. This is evident in a number of exhibitions presented by the George Fraser Gallery over the past five years, including 'Design Shanghai / Aesthetics City' (1 March - 12 April 2014), which showcased the award-winning exhibition co-curated by students from Elam School of Fine Arts and Shanghai University Art Academy at the international design competition 'Design Shanghai' in 2013. The exhibition involved developing a range of designs to enhance user experience of the Shanghai subway system. ${ }^{31}$ Furthermore, the George Fraser Gallery annually hosts the Elam Art Fair which is organised by the Elam Student Association and enables the public to view and purchase artworks created by Elam students and recent graduates. ${ }^{32}$ Similarly, the Gallery holds the annual 'Elam Graduate Show' which presents the artwork of more than 120 graduating Fine Arts students. The exhibition encourages the public to "take this chance to view their individual achievements and gain an insight into the challenges and rewards of earning a degree from Elam." ${ }^{, 33}$ Subsequently, the George Fraser Gallery becomes not only a site for the public presentation of student artwork, but also an open showpiece for the wider community to view some of the academic endeavours undertaken by the University's students.

\footnotetext{
${ }^{29}$ The Auckland Festival of Photography, “Anxious Production: Disrupting a Functionary Bond” (accessed 8 December, 2014).

${ }^{30}$ Stockman-Young, correspondence.

${ }^{31}$ NICAI, "Design Shanghai / Aesthetics City," the University of Auckland (accessed 28 October, 2014); and The University of Auckland, "Elam Students Win Award at International Design Exhibition" (accessed 28 October, 2014).

${ }^{32}$ NICAI, "Elam Art Fair," the University of Auckland (accessed 28 October, 2014).

${ }^{33}$ NICAI, "This Much is Certain - Elam Grad Show," the University of Auckland (accessed 31 October, 2014); NICAI, "Elam Graduate Show," the University of Auckland (accessed 30 October, 2014); and NICAI, "Elam Graduate Show," the University of Auckland (accessed 30 October, 2014).
} 


\section{Is the George Fraser Gallery a Post-Museum?}

Examining the above-mentioned exhibitions and activities staged at the Gus Fisher Gallery, questions do arise as to whether this university art gallery can be considered an example of a Post-Museum. As previously discussed, scholars argue that university museums and galleries are a "third space" positioned on the fringe of both the university and municipal environments. This role provides these organisations with a significant amount of freedom to experiments with new forms of visual arts practices and discourses. ${ }^{34}$ Marstine contends that it is this freedom which enables university art galleries to lead in the creation of the PostMuseum, which critiques the politics of representation and entrenched institutional narratives and structures. ${ }^{35}$

The student-driven nature of the George Fraser Gallery and its association with a Fine Arts school means that this Gallery has often staged exhibitions which critique the context and disposition of the gallery environment. For example, between 16 April and 3 May 2008 the George Fraser Gallery hosted 'Under Construction: Open Studio Practice by $4^{\text {th }}$ Year Elam Students' which presented a new model of utilising a gallery space to show contemporary art. The artists transformed the Gallery into both a working studio and an exhibition space and invited their fellow exhibitors as well as the visiting public to participate in the development of their work. The objective of this exhibition was to examine issues concerning "intimacy, unconsciousness, and the human condition, de/constructive thinking, invasion of space, and relationships with/between people and objects. ${ }^{, 36}$ In August 2009, a similar exhibition was staged in the George Fraser Gallery, entitled 'All Your Base are Belong to Us," which critiqued the nature of the Gallery, stating that: "The George Fraser Gallery operates as an event-only space, viewed as merely a place to debut and close events and exhibitions, retrospectives and collections." The aim of the exhibition was to "show how the space can be transformed from an event-only, formal edifice to a more organic and inspired space for artists to work and play." 37

\footnotetext{
${ }^{34}$ McCarthy, "The Politics of Display"; Marstine, "What a Mess!," 303.

${ }^{35}$ Marstine, "The Transformative Exhibition, the Museum Intervention, and the Transformative Pedagogy."

${ }^{36}$ NICAI, "Under Construction: Open Studio Practice by $4^{\text {th }}$ Year Elam Students" (accessed 31 October, 2014).

${ }^{37}$ NICAI, "All Your Base are Belong to Us," the University of Auckland (accessed 31 October, 2014).
} 
These two exhibitions show the way in which university art galleries can critique institutional narratives and conventions and challenge them with transparent and open-ended practices that enable students, staff and the public to become equal participants within the creative process. ${ }^{38}$ Unlike public art museums or curatorially-driven university art galleries, the student-centric nature of the George Fraser Gallery enables this Gallery to stage messy and informal exhibitions which contribute a unique perspective to current museum discourse. This is openly acknowledged by Stockman-Young who stated:

I feel like student-run spaces as less well put together and less well functioning [places], ... have an openness where we are not dependent on representing a larger body. We are just interested in representing the artists and students who are working at the time. So our work can explore and push out and it can be anything. We are allowed more freedom. ${ }^{39}$

\section{Conclusion}

As a student-centric university art gallery, the mission of the George Fraser Gallery is to "facilitate the development of an artist's/gallerist's career through early publicity and exposure and create a bridge between art students and the wider community." ${ }^{40}$ By striving to achieve this objective, the George Fraser Gallery subsequently becomes a space for interdisciplinary collaboration, a vehicle for forging and strengthening relationships with multiple cultural communities as well as the wider arts community, and a showpiece for the public presentation of the academic endeavours produced by students from the University of Auckland. Yet, due to its student-centric disposition and its position within an environment dedicated to the pursuit of high education, the George Fraser Gallery possesses a significant amount of freedom which enables it to stage "messy" and "radical" exhibitions and events. These factors enable the George Fraser Gallery to become an example of the emerging PostMuseum, a transparent entity which dismantles the voice of authority and critiques and examines the politics of representation. Therefore, the George Fraser Gallery assists its parent organisation in fulfilling its duty to be the "critic and conscience of society" as well as supporting the University in realising a number of its academic and strategic objectives. Yet, the potential of the George Fraser Gallery is largely underutilised and overlooked by its parent organisation. This may be due to the Gallery's alignment with the Elam School of Fine Arts, which may provide the impression to other disciplines and faculties that this space is

\footnotetext{
${ }^{38}$ Marstine, "The Transformative Exhibition, the Museum Intervention, and the Transformative Pedagogy."

${ }^{39}$ Stockman-Young, discussion.

${ }^{40}$ Ibid.
} 
confined to the Fine Arts School and solely dedicated to the display of visual arts. Or, as Stockman-Young said, it may be due to the "general nature of an institution like a university which does not always hold creative pursuits as a first priority." ${ }^{, 41}$ Whatever the reason may be, greater support of the George Fraser Gallery will not only produce a generation of greatly proficient professionals who will contribute and strengthen New Zealand's cultural and creative industry, but will also assist the university in achieving its mission, values, and objects. This dissertation will now go on to examine the Gus Fisher Gallery, a curatoriallydriven university art gallery that is also affiliated with the University of Auckland, to examine whether its experience is different in terms of how it is integrated into the institution.

${ }^{41}$ Stockman-Young, correspondence. 


\section{Chapter Three: The Gus Fisher Gallery at the University of Auckland}

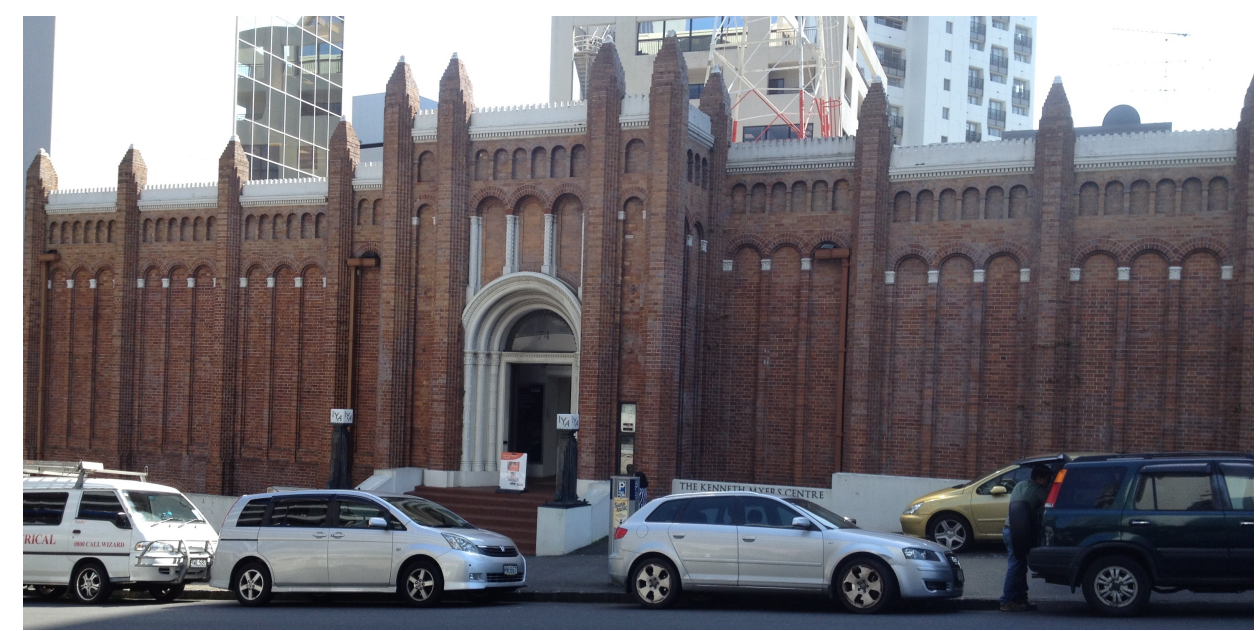

Figure 2: The exterior of the Gus Fisher Gallery, Shortland Street, Auckland. Image credit: Penelope Baines, 2014.

This chapter uses the Gus Fisher Gallery as an example of a curatorially-driven university art gallery and examines how and why this gallery has or has not integrated itself with its university constituencies. This case study also considers the ways in which the Gus Fisher Gallery contributes to the academic and strategic objectives of the University of Auckland. It investigates whether and in what ways the George Fraser Gallery encourages and nurtures student and staff involvement; and questions if the Gus Fisher Gallery can be considered an example of the emerging Post Museum.

\section{History and operations}

As outlined in Chapter One, the Gus Fisher Gallery opened on 3 March 2001 in the newly established Kenneth Myers Centre, which was the home of the School of Creative and Performing Arts (SCAPA). Upon its foundation, the Gus Fisher Gallery came under the governance of the Visual Arts Board, an advisory Board to the Vice Chancellor which comprised selected University staff members and well-known cultural philanthropists. The daily operations and programming of the Gallery was carried out by the Gallery Director and overseen by the Exhibitions Committee, a sub-committee of the Visual Arts Board. It was under this governance structure that the Gus Fisher Gallery instituted its mission statement 
and policy, both of which have remained unchanged. As previously stated, the objective of the Gus Fisher Gallery is: "To engage with current issues in the visual arts, promote understanding and foster critical debate through a programme of challenging, exhibitions based on active research." In order to carry out this mission, the Gus Fisher Gallery provides an exhibition programme which incorporates both historical and contemporary art exhibitions that primarily showcase the artwork of New Zealand and Pacific artists with occasional presentations of international artists.

Within four years of its establishment, the very existence of the Gus Fisher Gallery came under jeopardy when SCAPA underwent a review in 2004. This venture was instigated by the newly appointed Dean, Sharman Pretty, who oversaw the restructure of the Elam School of Fine arts, the closure of SCAPA, and the amalgamation of the Schools of Architecture and Town Planning. Instead, NICAI was established in order to encompass these schools along with the Gus Fisher Gallery, the School of Music, and the newly established Dance Studies Programme. ${ }^{2}$ This restructure also involved significantly reducing the Gus Fisher Gallery's funding, which caused the Gallery to question its ability to continue operating. ${ }^{3}$ According to the current Director, Linda Tyler:

Things became pretty scrutinised and very threatened in the Gus Fisher Gallery. So threatened in fact, Gus Fisher actually threatened to withdraw his funding unless the Gus Fisher Gallery was allowed to continue to operate. ${ }^{4}$

Due to its endangered position, the Gus Fisher Gallery was forced to prove its "worth" and "value" to the University of Auckland. The Gallery promoted itself as "a research site" with the capacity to publically present the academic undertakings of artists, curators, and writers through the means of exhibitions, publications, and public programmes. ${ }^{5}$ Subsequently, the Gallery was touted as a support mechanism for the Performance-Based Research Fund (PBRF) process, a government initiative which provides finance to tertiary institutions based on

\footnotetext{
1 The Gus Fisher Gallery Exhibitions Committee, "The Gus Fisher Gallery, University of Auckland" (Gus Fisher Gallery, Centre of Art Studies, University of Auckland, 26 November, 2001).

${ }^{2}$ Chris Barton, "University 'Chainsaw' Moves On," New Zealand Herald, 22 December, 2008.

${ }^{3}$ The Gus Fisher Gallery Exhibitions Committee, "Discussion Draft for the Gus Fisher Gallery” (Gus Fisher Gallery, Centre of Art Studies, University of Auckland, c. 2004); and Tyler, discussion.

${ }^{4}$ Tyler, discussion.

${ }^{5}$ The Gus Fisher Gallery Exhibitions Committee, "Discussion Draft for the Gus Fisher Gallery."
} 
research performance. ${ }^{6}$ The Gallery maintained that it provided PBRF opportunities by presenting:

- ... curatorial and creative work by academics as part of their research outputs;

- ... curatorial and creative work by other professionals not employed by this university as part of a benchmarking process;

- ... new and significant internal work to local audiences (including university academic staff and students) that would otherwise not be viewed in this country. ${ }^{7}$

By proving its value to its parent organisation, the Gallery also defined its niche within the wider arts community, distinguishing itself and its constituencies from other local galleries within the Auckland region. The Gallery argued that:

The Gus Fisher Gallery is the only art gallery in this city and one of few in this country which has as its core mission the imperative to exhibit research-based exhibitions which are the result of significant intellectual endeavour in curatorial and art practice. ${ }^{8}$

These arguments along with the displeasure expressed by the Fisher family, saw the dire situation resolved in late 2005 when it was announced that the Gus Fisher Gallery would be incorporated within NICAI's newly established Centre for New Zealand Art Research and Discover (CNZARD), now known as the Centre for Art Studies. Along with the Gus Fisher Gallery, the Centre also became responsible for the management and development of the University of Auckland Art Collection as well as supporting and guiding the student-curated gallery, Window. In December 2010 the Centre went under a review which concluded that: "In sum, CNZARD serves as a highly valued hub for intra-university and wider community research, education and relations that extends well beyond the fine arts." ${ }^{\prime 9}$ It also identified the Centre's significant role in assisting the University of Auckland and NICAI in achieving their strategic objectives, stating:

Most notably it is making a vital contribution to the University and NICAI's desire to build a national and international reputation; to expand and strengthen its relationships with the external communities especially the arts community, alumni, donors and citizens of Auckland; to promote disciplinary excellence and

\footnotetext{
${ }^{6}$ Tertiary Education Commission, "Performance-Based Research Fund" (accessed 30 December, 2014); and Ibid.

${ }^{7}$ The Gus Fisher Gallery Exhibitions Committee, "Discussion Draft for the Gus Fisher Gallery."

${ }^{8}$ Ibid.

${ }^{9}$ Brad Jackson, "Centre for New Zealand Art Research and Discovery Review Report" (Gus Fisher Gallery, Centre for Art Studies, University of Auckland, 20 March, 2011), 1.
} 
interdisciplinary innovation; and to provide a rich working and learning environment for an impressively large number of students and staff. ${ }^{10}$

Despite this the report also noted "...the range and depth of the strategic contribution that is being made by CNZARD is not being fully recognised or capitalised upon by the University. ${ }^{11}$

\section{The Gus Fisher Gallery and its role within the University}

One of the prominent ways in which the Gus Fisher Gallery is able to prove its value to the University of Auckland is to demonstrate its ability to serve as an innovative teaching tool and resource. As previously discussed, there has been an increasing need over the last thirty years for university art galleries to prove how their institutions contribute to the core business of their parent organisation. Consequently, many university art galleries have emphasised their pedagogical capability and have subsequently aligned themselves with the academic and strategic objectives of their universities. ${ }^{12}$

In the case of the Gus Fisher Gallery, this objective is evident in the Gallery's practice of hosting numerous exhibitions that showcase student artwork or are curated by postgraduate students. For example, in December 2013 and December 2014 the Gallery hosted the exhibition 'New Graduate Works', which invited any final year Bachelor of Fine Arts, Bachelor of Fine Arts with Honours or Fine Arts postgraduate student enrolled at Elam School of Fine Arts to submit an artwork produced during the course of their final year. From the artworks selected for the exhibition, the University of Auckland Art Collection Committee selects three pieces that are then purchased as part of the University's Art Collection. ${ }^{13}$ Furthermore, for the past two years, these exhibitions have been curated by the Gallery's curatorial assistants who have been Fine Arts graduates from Elam School of Fine Arts and previous curators of the student-run exhibition space Window. The 'New Graduate Works' exhibitions support emerging artists from the University's Fine Arts school not only by enabling them to take part in a group exhibition staged at a reputable art gallery, but also

\footnotetext{
${ }^{10}$ Ibid., 5.

${ }^{11}$ Ibid.

${ }^{12}$ For examples see: Goethals and Fabing, College and University Art Museums Program; Glesne, The Exemplary Museum; Snell, 'Valuing University Art Galleries'; and Wallace, “Challenges Facing University Museums'.

${ }^{13}$ NICAI, "New Graduate Works," the University of Auckland (accessed 3 November, 2014); and NICAI,

"New Graduate Works," the University of Auckland (accessed 12 June, 2014).
} 
by providing graduates with the opportunity to have their work included within one of New Zealand's most extensive permanent art collections.

In 2014 the Gus Fisher Gallery also hosted two exhibitions curated by Honours students from the Art History faculty. The first of these was entitled 'Voicing the Visible: Feminist Art from the University Art Collection' (9-31 May), which involved 18 students from the postgraduate Art History course, Art Writing and Curatorial Practice (ARTHIST734) selecting feminist artworks from the University of Auckland Art Collection and curating an exhibition. The Gus Fisher Gallery Director, Linda Tyler, who was also the lecturer of the paper, outlined the tasks required of the students:

My class did an exhibition and all of them had to write 500 words about one artwork, then we put the exhibition on with a catalogue. They had to do the condition reporting, they had to physically handle the objects and make them ready for exhibition. They had to learn what it was to light a show, promote it, develop the communication around it, and run the public programmes. So, they basically had it like a case study teaching tool. ${ }^{14}$

Similarly, the exhibition 'Gifted: Works Gifted to the University Art Collection (5 September - 1 November 2014) was curated by Maria-Constanza Labra-Odde, an Art History Honours students, and was sponsored by the University of Auckland Society, a charitable trust that provides opportunities to the University's graduates, staff, and friends. This exhibition selected a number of artworks that had been donated to the University of Auckland Art Collection and examined the symbolism surrounding the concept of gifted artwork and its vital role in forming collections. $^{15}$

These student-orientated exhibitions enable the Gus Fisher Gallery to achieve one of its primary goals of providing "a specialised platform matching [academic and] professional skills for graduates and postgraduate students in fine arts/arts, especially in art history/museology."16 Yet, it also communicates to students that the Gus Fisher Gallery is the University's art gallery and as such their voices should be represented and included within the Gallery's exhibitions and public programmes due to their fundamental significance within the University community. In doing so, the Gus Fisher Gallery not only provides students with invaluable

\footnotetext{
14 Tyler, discussion.

${ }^{15}$ NICAI, "Gifted," the University of Auckland (accessed 3 November, 2014).

${ }^{16}$ The Gus Fisher Gallery, "Plan Case Application" (The Gus Fisher Gallery, Centre for Art Studies, University of Auckland, c. 2004).
} 
learning experiences, but also conveys to them that the Gallery is a place for students to utilise and enjoy.

The Gus Fisher Gallery's ability to be utilised as a teaching tool is obvious in relation to the disciplines of Fine Arts and Art History; however, the Gus Fisher Gallery has also demonstrated the ways in which it had be a pedagogical apparatus for other disciplines such as Engineering and Foreign Languages. For example, at least two lecturers from the Mechanical Engineering department at the University of Auckland utilise the Gallery in their teaching. Tyler explained the ways in which this subject used the Gus Fisher Gallery:

So, regularly now, once a week, we have mechanical engineering that comes in it's straight out of the Bauhaus - they come in and basically respond to an artwork and they are given very basic card, paper, glue, tools and they have to make something. They have to make something in response to the artwork and that is testing their constructional knowledge. They are there for three hours on the Thursday and make an unholy mess in the foyer and I think it's great! I often put them on Facebook because they do come up with some wonderful things. Nobody would expect the mechanical engineering department to be the least bit interested in the Gus Fisher Gallery. ${ }^{17}$

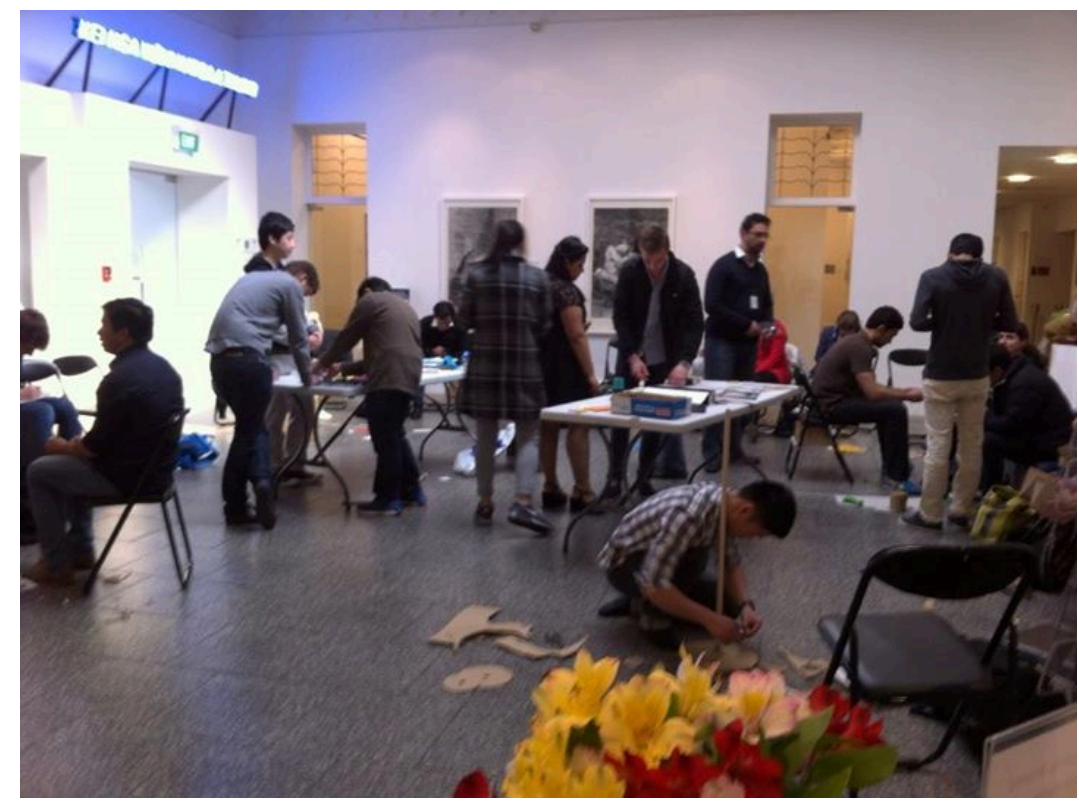

Figure 3: A class from the University of Auckland engineering department using the Gus Fisher Gallery. Image credit: Linda Tyler.

According to Tyler, foreign language classes also make use of the Gallery. Students are tasked with the challenge of discussing the artworks in their second language, an exercise which helps

${ }^{17}$ Tyler, discussion. 
them build knowledge of specialist words such as picture, landscape, painting, portrait, and so on. ${ }^{18}$ Yet, there are some challenges to utilising the Gus Fisher Gallery in teaching. According to one University lecturer, the fast paced turnover of exhibitions makes it hard to plan ahead, and sometimes exhibitions that are held in the Gallery do not suit the types of exercises required for classes. It was also noted that for first-year classes the number of students can total upwards of 80 , making the small spaces of the Gus Fisher gallery a logistical impediment. ${ }^{19}$

In order to raise awareness of the Gus Fisher Gallery and the University of Auckland Art Collection, Tyler has held a number of mid-winter breakfasts for staff at the Gallery. Tyler explained that staff are invited to the Gus Fisher Gallery in order to:

... have a coffee, tea, croissant, listen to me rave on about the [current] exhibition, and go away with a memory stick with the [University of Auckland Art] collection on it. Then they can think of the ways they may use the Collection in their teaching. That's really increased the uptake of programmes that come to the Gallery, especially in languages. It's had a really desirable effect in that regard. ${ }^{20}$

Another way in which the Gus Fisher Gallery showcases its disciplinary value is by hosting exhibitions in conjunction with academic conferences. In 2008, the Gallery held an exhibition entitled 'The Power of Portraiture' (28 November 2008 - 24 January 2009), which was organised to coincide with the $7^{\text {th }}$ International Conference on Studying Leadership hosted by the University of Auckland between 7-9 December 2008. ${ }^{21}$ The exhibition displayed 40 portraits of major public figures from a variety of different professional backgrounds. According to the show's description: “... the exhibition complements the more academic insights of leadership by providing an alternative point of access for members of the public to debate and question the role of leadership in today's society."22 More recently, the Gallery staged 'Art of the Invisible: Exploring the World of Nanotechnology' (8-23 February 2013), which was held in conjunction with AMN6: The $6^{\text {th }}$ International Conference on Advanced Materials and Nanotechnology hosted by the University of Auckland's Business School and

\footnotetext{
${ }^{18}$ Ibid.

${ }^{19}$ Auckland University staff member, in discussion with author, 25 September, 2014.

${ }^{20}$ Tyler, discussion.

${ }^{21}$ NICAI, "The Power of Portraiture: Curated by Erin Griffey," the University of Auckland (accessed 12 June, 2014).

${ }^{22}$ Ibid.
} 
the MacDiarmid Institute. ${ }^{23}$ The exhibition presented images of the research undertaken by New Zealand nanotechnology graduate students and exposed the aesthetic beauty present within these scientific images.

\section{The Gus Fisher Gallery and its role for the University}

In 2005 the University of Auckland announced its strategic plan for the years 2005 to 2012. One of the objectives proclaimed the institution's ambition to: "Develop effective partnerships with the University's local, national and international communities. " 24 The Gus Fisher Gallery's contribution to this strategic objective is evident in its efforts to form relationships with the wider arts community as can be seen in the Gallery's involvement in regional arts festivals and nationally touring exhibitions. For example, the Gus Fisher Gallery has taken part in four of the last five Auckland Triennials. The first of these was the Gallery inaugural exhibition, entitled 'Bright Paradise' (3 March - 29 April 2001) which displayed prominent New Zealand artists, Bill Culbert and Patrick Pound alongside the American artist Sabina Ott. ${ }^{25}$ In 2004, the Gallery took part in the $2^{\text {nd }}$ Auckland Triennial PUBLIC/PRIVATE Taumatanui/Tumataiti (20 March - 30 May) followed by the $3^{\text {rd }}$ Auckland Triennial, 'Turbulence' (9 March - 28 April) in 2007. ${ }^{26}$. More recently, the Gus Fisher Gallery was an exhibition partner in the $5^{\text {th }}$ Auckland Triennial (10 May - 11 August 2013) and showcased artworks by Anri Sala, Claire Fontaine, and Tahi Moore. ${ }^{27}$

The Gus Fisher Gallery also participates in the annual Auckland Festival of Photography which takes place at various galleries and locations around Auckland. In 2014, the Gallery presented three exhibitions for this festival: 'Therapies: Photographs by Christine Webster' (931 May); 'History in the Taking: 40 Years of PhotoForum' (6-28 June); and 'Grills' (30 May 28 June).

\footnotetext{
${ }^{23}$ NICAI, "Art of the Invisible: Exploring the World of Nanotechnology," the University of Auckland (accessed 12 June, 2014).

${ }^{24}$ The University of Auckland, The University of Auckland Strategic Plan 2005-2012 (Auckland: The University of Auckland, c. 2006), 7 (accessed 9 February, 2015).

${ }^{25}$ Tyler, discussion; Allan Smith, ed., Bright Paradise: The First Auckland Triennial (Auckland: Auckland Art Gallery Toi o Tāmaki, 2001).

${ }^{26}$ Victoria Lynn, Turbulence: The $3^{\text {rd }}$ Auckland Triennial (Auckland: Auckland Art Gallery Toi o Tāmaki, 2007).

${ }^{27}$ NICAI, " $5^{\text {th }}$ Auckland Triennial," the University of Auckland (accessed 15 June, 2014).
} 
By participating in popular public art festivals such as the Auckland Triennial and the Auckland Festival of Photography, the Gus Fisher Gallery not only strengthens ties with the wider arts community, but also commands prestige and exposure for NICAI as well as the University of Auckland in general. For instance, the 'History in the Taking' took place in association with the publication of PhotoForum at 40: Counterculture, Clusters and Debate in New Zealand which examines the history of PhotoForum, an organisation which has seen the involvement of a number of photography students and teachers from Elam School of Fine Arts. ${ }^{28}$ Similarly, 'Grills' presented photographs of nifo koula (gold teeth) captured by Ane Tonga, a graduate of Elam School of Fine Arts as well as the University's Museums and Cultural Heritage programme. Likewise, in 2013, Sholto Buck, a Fine Arts student at Elam School of Fine Arts, presented his work in the exhibition 'Interlude'; and in 2012 the Gallery hosted an exhibition of Auckland University alumnus, Peter Peryer, in 'Peter Peryer: Other Portraits (1975-2011)'.

The Gus Fisher Gallery's involvement in these regional art festivals and its exhibition of significant artists like Peter Peryer, who are Auckland University alumni, alongside emerging artists such as Tahi Moore, Sholto Buck, and Ane Tonga, means that the Gus Fisher Gallery effectively and widely publicises the significant creative talent produced by the University as well as its prevailing influence within New Zealand's cultural sector. The Gus Fisher Gallery, therefore, is an effective vehicle through which the University can convey these factors to the wider arts community and the general public.

The Gus Fisher Gallery's role as a showpiece for the University of Auckland is also demonstrated in its continual practice of hosting exhibitions that present the creative and academic endeavours of University staff. These exhibitions include showcases of current Fine Arts faculty members at Elam School of Fine Arts who also continue with their own personal artistic practice. For example, in 2010 the exhibition 'Exploded View' (4 June - 17 July) presented an immersive installation of printed and collaged works by Associate Professor Nuala Gregory. ${ }^{29}$ Similarly, Sean Kerr, a Senior Lecturer at Elam School of Fine Arts, presented a survey of his new media and interactive art in the exhibition 'Bruce Danced if Victoria Sang, and Victoria Sang; so Bruce Danced' (3 September - 2 October 2010).

\footnotetext{
${ }^{28}$ For instance, the founding editor and PhotoForum director, John Turner, was a previous lecturer in Photography at Elam School of Fine Arts, and past members include Megan Jenkinson who is currently an Associate Professor at Elam.

${ }^{29}$ NICAI, "Nuala Gregory: Exploded View," the University of Auckland (accessed 3 November, 2014).
} 
In conjunction with these exhibitions the Gus Fisher Gallery also hosts numerous shows based on the academic research of staff from other disciplines including Art History, Architecture, and Psychology. For example, in 2010 the Gallery presented the exhibition 'Group Architects: Towards a New Zealand Architecture' (15 October - 27 November) which was held in conjunction with the publication of a book on the subject written by Dr Julia Gatley from the School of Architecture and Planning. ${ }^{30}$ The exhibition displayed drawings, photographs, models, furniture, paintings, and sculptures by a group of mid-twentieth century New Zealand architects and also included models created by three Architecture students from the University of Auckland. ${ }^{31}$

Similar exhibitions have also taken place presenting the research of staff from the faculty of Art History. In 2011, Professor Elizabeth Rankin curated 'Collateral: Printmaking as Social Commentary' (1 July - 20 August), which examined this medium's predisposition for social and political critique. The exhibition presented Rankin's research on four printmakers, Daniel Heyman, Michael Reed, Sandra Thomson, and Diane Victor, who utilise the versatility of the print process in order to expose the suffering of people who are indirectly involved in human rights violations and conflict. ${ }^{32}$ The exhibition included works which explored the interrogation of Iraqi detainees, corruption and tragedy in post-Apartheid South Africa, abuse within the Catholic Church, and the production and trade of arms and weaponry. More recently, the Gus Fisher Gallery hosted 'A Different View: Artists Address Pornography' (23 August - 12 October 2014) which was curated by Associate Professor Linda Tyler, and Associate Professors Virginia Braun and Nicola Gavey from the School of Psychology. This exhibition was part of a broader project entitled 'Pornography in the Public Eye' which examines the place of pornography in contemporary New Zealand culture. 33 'A Different View' brought together 20 New Zealand artworks in order to question the misogynistic, sexist, and racist conventions of pornography and its influence on mainstream society. ${ }^{34}$

\footnotetext{
${ }^{30}$ Julia Gatley, ed., Group Architects: Towards a New Zealand Architecture (Auckland: Auckland University Press, 2010).

${ }^{31}$ NICAI, "Group Architects: Towards a New Zealand Architecture," the University of Auckland (accessed 3 November, 2014).

${ }^{32}$ NICAI, "Collateral: Printmaking as Social Commentary," the University of Auckland (accessed 19 June, 2014).

${ }^{33}$ For more information see: "The Project," Sexual Politics Now (accessed 12 January, 2015).

${ }^{34}$ NICAI, "A Different View: Artists Address Pornography," the University of Auckland (accessed 15 June, 2014).
} 
These examples demonstrate the way in which the Gus Fisher Gallery acts as a platform for the presentation of academic projects undertaken by staff at the University of Auckland. Often, universities are viewed as private spaces that are closed to the public and restricted to students, staff, and other researchers. Therefore the Gus Fisher Gallery fulfils an important role in connecting with the wider public and communicating the University's activities and achievements to a broad audience. This also plays a significant role for academic staff who are expected to achieve specific requirements for the PBRF process. By presenting their research at the Gus Fisher Gallery in the format of a public exhibition that is selected by a committee as part of a peer review process, the Gallery can be utilised as a mechanism for staff to achieve their PBRF requirements. ${ }^{35}$ This factor was identified by Tyler, who stated:

There is a big difference between an institution like what the City Gallery [Wellington] does, which is serve artists and serve a public which is hungry to see developments in the visual arts, and what a university art gallery can do which is often to serve the needs of academics to have a broader audience for their research. Also for students to have an opportunity to see the ways in which research can be presented in unusual ways and to bring in a larger interest in the exhibition product. ${ }^{36}$

The two exhibitions 'Collateral: Printmaking as Social Commentary' and 'A Different View: Artists Address Pornography' can also be considered examples of the Gus Fisher Gallery assisting its parent organisation in fulfilling its role as the "critic and conscience of society." By discussing controversial issues such as suffering within the Catholic Church, human rights violations in the Middle East, and pornography's insidious influence within mainstream society, the Gus Fisher gallery can be thought of as a forum "to question and test received wisdom, to put forward new ideas and state controversial or unpopular opinions." ${ }^{, 37}$ According to Tyler:

That's one way in which we [as a university art gallery] can be a critic and conscience, and perhaps do things that are allied more with academic research and less to do with the idea of blockbuster shows and bums on seats. ${ }^{38}$

Yet, unlike the George Fraser Gallery, which stages "radical" and "messy" student-driven exhibition which clearly expresses its role as a university art gallery, the Gus Fisher Gallery stages highly professionalised and polished showcases and public programmes which are

\footnotetext{
${ }^{35}$ The Gus Fisher Gallery Exhibitions Committee, "Discussion Draft for the Gus Fisher Gallery."

${ }^{36}$ Tyler, discussion.

${ }^{37}$ New Zealand Education Act 1989, pt 14, s 161, subs 2(a).

${ }^{38}$ Tyler, discussion.
} 
dominated by a curatorial or academic voice of authority. By hosting these types of 'slick' exhibitions that mirror those staged by civic or public art galleries and museums, it could be argued that the Gus Fisher Gallery is at risk of losing its niche identity of being a university art gallery. ${ }^{39}$

In addition to its role as a public interface for the University of Auckland, the Gus Fisher Gallery also assists its parent organisation in achieving its strategic objective surrounding the establishment of relationships with Auckland's growing Māori, Pacific Island, and Asian communities. ${ }^{40}$ In 2010, Tyler identified that the Gus Fisher Gallery's location in downtown Auckland situates the Gallery within New Zealand largest demographic of Asian residents. Consequently, it was decided to appoint an Asian artist as a representative on the Gallery's Advisory Board in order to include the viewpoint of this group in the Gallery's exhibition and public programming. Liyen Chong, an Auckland based artist who is Malaysian-Chinese descent, was subsequently recruited for the role, and has served on the Board for the last five years, overseeing the Asian-orientated programming. ${ }^{41}$

Furthermore, the Gus Fisher Gallery also works with the Pacific arts organisation, Tautai, and incorporates their shows and events within the Gallery's exhibitions and public programme. Tautai does not have a permanent gallery space but instead collaborates with other institutions in order to support Pacific Island artists to present their work. In 2013, the Gus Fisher Gallery hosted the exhibition and performance series 'More Than We Know' (6-22 March), which included artists Jeremy Leatinu'u and Kalisolaite 'Uhila and was curated by Ioana GordonSmith. Moreover, in 2015, the Gallery will present 'Blackbird: A Survey of the Work of Lonnie Hutchinson', and in 2017 will present a showcase of artwork by Dagmar Dyck. ${ }^{42}$ According to Tyler these exhibitions enable the Gallery "... to have greater reach into Pasifika communities in areas not traditionally associated with the University's constituency." 43 These examples show that by establishing relationships with the wider community of creative practitioners and organisations, the Gus Fisher gallery becomes an effective instrument for the University in achieving its strategic objectives regarding the development of relationships with Auckland's increasingly diverse cultural communities.

\footnotetext{
${ }^{39}$ See more about this argument in Marstine, "What a mess!".

${ }^{40}$ The University of Auckland, The University of Auckland Strategic Plan 2013-2020, 14; and "The University of Auckland Charter 2003," The University of Auckland, Sections VI and VII (accessed 17 November, 2014).

${ }^{41}$ Linda Tyler, e-mail correspondence with the author, 15 December, 2014.

${ }^{42}$ Ibid.

${ }^{43}$ Ibid.
} 


\section{Is the Gus Fisher Gallery a Post-Museum?}

As previously discussed, a number of Museum Studies scholars suggest that university art galleries have the potential to lead in the creation of the Post-Museum because of the significant amount of freedom they possess due to their position on the fringes of both the university and municipal environments. ${ }^{44}$ In her presentation "The College Museum: A Collision of Discipline, A Laboratory of Perception Conference", delivered at the Francis Young Tang Teaching Museum and Art Gallery in Saratoga Springs, Marstine urged university art galleries to stage exhibitions that critiqued institutional narratives and conventions. Marstine highlighted the suitability of initiating museum interventions in order to enable museum staff and audiences to participate in a critical discourse about the nature of power and representation. ${ }^{45}$ In 2012, the Gus Fisher Gallery hosted one such exhibition entitled 'Hutton and Cotton: The McGregor Museum Revisited' (20 January - 3 March), an installation by Christine Hellyar which examined the partly-demolished McGregor Museum in the School of Biological Sciences at the University of Auckland. ${ }^{46}$ The collections of the McGregor Museum were established by Professor A. W. P. Thomas in 1884, and were originally accommodated on the first floor of the University's Old Choral Hall. In 1939 a purpose-built space for the collection was constructed in the Old Biology Building and was later named in honour of Professor W. R. McGregor who assumed responsibility for developing the museum's collections and exhibitions as Curator and Head of Zoology. ${ }^{47}$ Subsequently, Hellyar's installation critiqued the content and displays of the McGregor Museum by presenting biological specimens, images, and bones in some of the cabinets and drawers saved from the McGregor Museum. By staging 'Hutton and Cotton: The McGregor Museum Revisited,' the Gus Fisher Gallery exercised a significant degree of institutional reflexivity, enabling audiences to critique the institutional nature of museums and galleries, and reflect upon the constructed and political nature of representation within these types of organisations.

\footnotetext{
${ }^{44}$ McCarthy, "The Politics of Display"; Marstine, "What a Mess!," 303; and Marstine "The Transformative Exhibition, the Museum Intervention, and the Transformative Pedagogy."

${ }^{45}$ Marstine, "The Transformative Exhibition, the Museum Intervention, and the Transformative Pedagogy."

${ }^{46}$ NICAI, "Hutton and Cotton: The McGregor Museum Revisited," the University of Auckland (accessed 12 June, 2014).

${ }^{47}$ Ibid.
} 


\section{Conclusion}

The abovementioned endeavours undertaken by the Gus Fisher Gallery demonstrate its many contributions to the University of Auckland. As the official art gallery of the University, the Gus Fisher Gallery is a public showpiece for the academic and creative scholarship of staff, students, and alumni. Yet, the Gallery has also proven its value to the University in a number of other ways, including its potential to be utilised as an innovative and interdisciplinary teaching tool and resource, as well as a mechanism through which academic and strategic objectives can be achieved. As Tyler puts it:

... I firmly believe that if you have meetings with staff, if you have talks with students, if you're constantly engaging with your backyard, then the more they will feel some sense of ownership with the place and embrace it and use it. You may not have the leading role in the visual arts nationally or internationally, but you will have a much loved and much used institution. I would much rather have that. $^{48}$

Due to the Gus Fisher Gallery's capacity as the official art gallery of the University of Auckland, the Gallery does lack some of the messy and radical disposition that is evident in many of the exhibitions held at student-driven university art galleries such as the George Fraser Gallery. Instead, the exhibitions programme contains a series of highly polished and professional presentations produced by top scholars and curators utilising the artwork of established national and international artists. Despite this immensely formal persona, the Gus Fisher Gallery does not shy away from including student artwork in their shows and hosting student-curated exhibitions. After all, as Laurence Vail Coleman argued: “... unless [university or college] museums are conspicuously useful in their proper work - that is, work with students - they are inadequate, and no extenuating circumstance can alter that fact."49

In spite of the Gus Fisher Gallery's significant contribution in assisting the University to achieve its academic and strategic objectives, the Gus Fisher Gallery - like the George Fraser Gallery - is largely underutilised and overlooked by its parent organisation. ${ }^{50}$ One reason for this, which has already been identified, may to be due to the general nature of universities

\footnotetext{
48 Tyler, discussion.

${ }^{49}$ Coleman, College and University Museums, 5, quoted in Bradley, "Curricular Connections."

${ }^{50}$ See: Jackson, "Centre for New Zealand Art Research and Discovery Review Report," 5; and Barton, discussion.
} 
which do not always prioritise creative pursuits, instead concentrating on prestigious and income-generating disciplines such as the sciences, engineering, law, and commerce. ${ }^{51}$

However, another cause may be the fact that university management is often simply unfamiliar with the institution of an art gallery and are, therefore, ignorant of their purpose, potential, and administration processes. Consequently, this means management often expects university art galleries to perform to a high level with little financial investment and minimal human resources. This factor was highlighted by Tyler, who states:

There is a gap in interest, engagement and advocacy. There is a big gulf between what they [management] see being achieved - they see the duck and they don't see the frantic paddling underneath the water. What they see is the outcomes and they don't really understand, because it's not their area of expertise, any of the work that goes into getting that duck to float on the water and to seem to move effortlessly. $^{52}$

University management needs to gain a better understanding not only of the administration processes of a university art gallery, but also their purposes and potential. Universities need to realise that their galleries can serve as hubs " ... for intra-university and wider community research, education, and relations that extends well beyond the fine arts." ${ }^{, 53}$ How to get university management to realise these factors, however, goes far beyond the scope of this thesis.

\footnotetext{
${ }^{51}$ Stockman-Young, correspondence.

52 Tyler, discussion.

${ }^{53}$ Jackson, "Centre for New Zealand Art Research and Discovery Review Report," 1.
} 


\section{Conclusion: From the margins to the core}

Within this examination of New Zealand university art galleries, one conclusion is explicitly clear - these organisations are undertaking a number of endeavours in order to positively contribute to their parent organisations. No matter whether these galleries can be classified as professionalised curatorially-driven or student-centric spaces aligned with a fine arts school, for the most part these galleries are striving to become an integral part of their university communities. This undertaking should not be underrated as these galleries accomplish significant activities with little recognition from their parent organisation, scant resources, and few personnel.

As has been shown by the case studies of the George Fraser Gallery and the Gus Fisher Gallery at the University of Auckland, these galleries serve as important interfaces between the University and the public, showcasing the academic and creative scholarship undertaken by the University's staff, students, and alumni. By doing so, university art galleries not only contribute to the education of its students and assist staff to achieve Performance-Based Research Fund requirements, but they also contribute to the general education of the wider community. ${ }^{1}$ By showcasing exhibitions that involve staff, students, and successful alumni, these galleries not only generate prestige for their parent organisations, but also serve as enticing facilities to prospective students, which is an important matter given the increasingly competitive nature of the tertiary sector. ${ }^{2}$

In conjunction with their role as a public showpiece for their universities, New Zealand university art galleries have also proven to be effective resources for achieving the academic and strategic objectives of their parent organisations. As has been identified in the examination of the George Fraser Gallery and the Gus Fisher Gallery, their participation within regional arts events such as the Auckland Triennial and the annual Auckland Festival of Photography mean these organisations assist the University in establishing and fostering relationships with the wider arts community. Likewise, by collaborating with multicultural groups such as the Tuākana mentoring programme and Tautai to stage exhibitions and public programmes, the

\footnotetext{
${ }^{1}$ Kelly, "Introduction," in Managing Museums, 11-12.

${ }^{2}$ Cobley, "Art Spaces as Research Stations," 24.
} 
George Fraser Gallery and the Gus Fisher Gallery have proven themselves to be valuable mechanisms for helping the University to achieve its strategic objective of forming relationships with Auckland's increasingly diverse cultural communities. ${ }^{3}$

Furthermore, the fact the university art galleries can be considered liminal entities, situated on the fringes of both the university and municipal gallery environments, means that these institutions possess a significant amount of freedom. As one university art gallery director states:

... [University art galleries] are protected and nurtured within the context of an institution dedicated to higher learning and to the profound ideals of knowledge production and research. ... [W]e are in a privileged position of putting thinking and exploration and experimentation ahead of audience numbers, bums on seats, [and] financial requirements to make money. ... [We can] aim to inspire and stimulate and question and challenge, and not simply entertain. ${ }^{4}$

Consequently, university art galleries have the potential to assist their parent organisation in fulfilling their duty to be the "critic and conscience of society" and "to question and test received wisdom, to put forward new ideas and state controversial or unpopular opinions" as outlined in the New Zealand Education Act (1989). ${ }^{5}$ As evident in the case studies of the George Fraser Gallery and the Gus Fisher Gallery, these university art galleries stage exhibitions and public programmes that critique controversial social issues. This can be seen in the George Fraser Gallery's exhibition 'Argo Aotearoa', and 'A Different View: Artists Address Pornography' and 'Collateral: Printmaking as Social Commentary' at the Gus Fisher Gallery. Yet these two university art galleries present these critiques in two very distinctive ways. As a student-centric art gallery, 'Argos Aotearoa' at the George Fraser Gallery probed the nature of the university as an institution and asked visitors to express their views upon the walls of the Gallery.

This kind of exhibition aligns itself with Janet Marstine's idea of "messy" and "radical" student-driven exhibitions which encourage students to question and critique accepted

\footnotetext{
${ }^{3}$ The University of Auckland, The University of Auckland Strategic Plan 2013-2020, 14; and The University of Auckland, "The University of Auckland Charter, 2003," sections VI and VII.

${ }^{4}$ Barton, discussion.

${ }^{5}$ New Zealand Education Act 1989, Pt 14, s 162, subs 4(a), cl (v); and Pt 14, s 161, subs 2(a).
} 
institutional narratives. ${ }^{6}$ The gritty, unpolished, and critical exhibit differs a great deal from the highly professionalised showcases staged by the Gus Fisher Gallery. Due to its position as the official art gallery of the University of Auckland, it could be argued that the Gus Fisher Gallery is restricted in its ability to stage "messy" exhibitions which discard the traditional practice of exercising a dominant curatorial or academic voice of authority. As such, I believe that Marstine's argument that university art galleries have the potential to lead in the creation of the Post-Museum is possible, and is taking place within the student-centric university art galleries, such as the George Fraser Gallery, rather than the professionalised, curatoriallydriven university art galleries. However, this is rather unsurprising given the tendency of tertiary students to critique and express their dissent towards the authority of bureaucratic institutions. 'Argos Aotearoa' is an example of the way in which student-centric university art galleries can stage exhibitions that dismantle the voice of authority and relinquish this role to the staff and students of the university, all the while critiquing and examining the politics of representation and the nature of entrenched institutional narratives.

The Gus Fisher Gallery and the George Fraser Gallery have also demonstrated the ways in which university art galleries can serve as innovative and interdisciplinary teaching tools and resources. The galleries are important educational devices for students specialising in fine arts, art history, and museum studies. This pedagogical purpose is at the very core of the George Fraser Gallery's mission, as is evident in Jaimee Stockman-Young's statement that the Gallery is:

... an environment for students to learn not only about the running of a gallery, curation of a gallery, and [gaining] day-to-day work experience... but has also become an environment to test out and learn the manner to which you go about being a real artist. $^{7}$

The Gus Fisher Gallery also provides significant educational experiences by hosting studentcurated shows such as 'Voicing the Visible: Feminist Art from the University Art Collection', as well as 'New Graduate Works' which exhibited the artwork of final year fine arts students at Elam School of Fine Arts and provided them with the opportunity of having their work purchased as part of the University of Auckland Art Collection.

\footnotetext{
${ }^{6}$ Marstine, "What a Mess!”,303. Also see King and Marstine, "The Role of the University Art Museum and Gallery," 22-25.

${ }^{7}$ Stockman-Young, discussion.
} 
Although many of the Galleries' activities are unsurprisingly associated with the disciplines of fine arts, art history, and museum studies, there are examples of these Galleries serving more unconventional subjects. This can be seen in exhibitions such as 'Resonate', 'Argos Aotearoa', and '5 Futures: Award-Winning Projects from Recent Graduates', which were held in collaboration with musicians, writers, and architectures students from the University. Similarly, the Gus Fisher gallery has proven its interdisciplinary value by hosting exhibitions in conjunction with a variety of academic conferences including 'The Power of Portraiture' for the $7^{\text {th }}$ International Conference on Studying Leadership, as well as 'Art of the Invisible: Exploring the World of Nanotechnology' in conjunction with the $6^{\text {th }}$ International Conference on Advanced Materials and Nanotechnology. The Gus Fisher Gallery is also regularly visited by engineering and foreign language classes who utilise the space and the artworks within it for stimulating and alternative learning exercises.

Yet, I contend that to some extent the potential of the Gus Fisher Gallery and the George Fraser Gallery to be utilised as interdisciplinary teaching tools and resources is curtailed by the Galleries' affiliation with the National Institution of Creative Arts and Industries. Although this association does of course have administrative advantages, it does seem that staff and students from other disciplines with the University view them as spaces reserved for NICAI and art history, rather than spaces that can include their own discipline. However, it is also clear that both the director of the Gus Fisher Gallery and the gallery co-ordinator of the George Fraser Gallery are aware of this and are undertaking measures in order to change this perception. This is evident in the early morning breakfasts held for staff at the Gus Fisher Gallery, during which staff are informed of current and upcoming exhibitions and are provided with an inventory of the University of Auckland Art Collections. These kinds of activities have seen an increased uptake of programmes using the Gallery. More endeavours like these need to be undertaken by the galleries in order to show the ways in which they can contribute to multiple disciplines, including those situated outside of the humanities.

However, this may be difficult to achieve due to the small number of staff employed at both galleries.

Despite the considerable contribution that New Zealand university art galleries provide to their universities, they continue to be largely overlooked by their parent organisations. There are a number of reasons why this may be the case: Firstly, universities have become increasingly focused on investing more resources into prestigious and income-generating 
disciplines such as the sciences, engineering, law, and commerce. It seems that visual arts are only supported if a prominent figure within higher management has a personal interest in the arts. As a result, support for institutions such as the Gus Fisher Gallery and the George Fraser Gallery waxes and wanes according to personal interest and priorities of the university's management. Secondly, management are often unfamiliar with the administrative processes of an art gallery, and therefore expect significant outcomes with little financial investment and few human resources. This factor is summarised by Linda Tyler, who stated:

There is a gap in interest, engagement and advocacy. There is a big gulf between what they [management] see being achieved - they see the duck and they don't see the frantic paddling underneath the water. What they see is the outcomes and they don't really understand, because it's not their area of expertise, any of the work that goes into getting that duck to float on the water and to seem to move effortlessly. ${ }^{8}$

Lastly, and most importantly, New Zealand university art galleries often feel that they are viewed by university management as superfluous and not "core business." Yet, this study has demonstrated that New Zealand university art galleries $d o$ contribute in a significant way to the academic and strategic ambitions of their parent organisations. Therefore, universities need to recognise the potential of these overlooked resources and capitalise upon their capabilities and benefits.

In their discussion of the role of the university art museum and gallery, Anna Hammond in association with seven other directors of American university art museums, identified the increasing trend within these organisations to assert and cultivate their unique pedagogical identity. ${ }^{9}$ Yet, within New Zealand a number of university art galleries are struggling to achieve a balance between serving as a forum for teaching and functioning as a prestigious showpiece for the university. As an official agent of their parent organisations, some curatorially-driven university art galleries concern themselves with hosting sophisticated exhibitions that showcase the work of recognised national and international artists.

Curatorially-driven university art galleries consider themselves to be formal spaces and as such they are reluctant to relinquish the voice of authority in order to allow students to curate and produce "messy" and "radical" student-driven exhibitions.

\footnotetext{
${ }^{8}$ Tyler, discussion.

${ }^{9}$ Hammond et al., "The Role of the University Art Museum and Gallery," 25-28.
} 
However, whether university art galleries are curatorially-driven or student-centric, I would argue that they need to recognise and embrace the fact that they are a university art gallery and as such their duty is first and foremost to their students and staff. This means that university art galleries need to ensure that they are providing enough educational opportunities for their students alongside their programme of prestigious exhibitions. These educational experiences may take the form of students curating their own exhibition utilising the university's art collection, or display the work of fine arts, visual design, or architecture students within the gallery space. Whatever form they may take, New Zealand university art galleries need to embrace their pedagogical responsibilities alongside their role as a prestigious showpiece for their parent organisation. If they do not assert and cultivate this unique characteristic, then it might be asked: what prevents curatorially-driven university art galleries from being viewed a civic art gallery simply located within and funded by a university? As Linda Tyler explained, "You may not have the leading role in the visual arts nationally or internationally, but you will have a much loved and much used institution." 10

As pointed out in the Introduction, there has been little research undertaken in relation to the subject of university art galleries within New Zealand Aotearoa. This dissertation is the first examination of university art galleries in this country and provides a valuable overview of these organisations by situating them in relation to British and American theory. Therefore, there is much scope within this topic for further research. Due to the restrictions of this research dissertation, only two case studies were able to be undertaken. Subsequently there is the possibility that future research could examine the other five university art galleries which were unable to be included within this study. In-depth case studies of these university art galleries may display different patterns of operation or alternative working relationships with their parent organisations.

Another avenue of further research may include an examination of the fruitful relationships between other tertiary institutions and their exhibiting spaces. Many polytechnics and wānanga are undertaking exciting and innovative initiatives and these activities may be of benefit to the discipline of museology within New Zealand. Additionally, future researchers may gain from investigating the relationships between universities and civic museums and galleries within this country. This research may encompass whether any such relationships

${ }^{10}$ Tyler, discussion. 
have been established, what the potential may be for establishing these associations, and whether these connections are being exploited for their utmost benefit.

However, the most pertinent avenue for further research into university art galleries in New Zealand is examining how these organisations can be more valued by their parent organisations. This dissertation has revealed the issue that university art galleries significantly contribute to their universities but continue to remain overlooked and underutilised. Therefore, future researchers could examine how this issue may be resolved. This may be achieved by undertaking a broad examination of the university art galleries in New Zealand, identifying the most successful relationships, and assessing what makes these relationships fruitful and why this is so.

The topic of university art galleries within New Zealand is an exciting and relatively unexplored subject. Therefore, it is highly recommended that future researchers contemplate this subject when selecting possible research projects. Despite being small and few in number, New Zealand university art galleries are significant organisations within this country's cultural and education sectors and their contribution needs to recognised and commended. After all, what other cultural institution in today's society would consider themselves "privileged", and be able to put "thinking and exploration and experimentation ahead of audience numbers, bums on seats, [and] financial requirements to make money"'? ${ }^{11}$

\footnotetext{
${ }^{11}$ Barton, discussion.
} 


\section{Bibliography}

\section{Books and Chapters:}

Anderson, Gail, ed. Reinventing the Museum: The Evolving Conversation of the Paradigm Shift. Lanham, MD: AltraMira Press, 2012.

Boylan, Patrick J. “The Museum Profession.” In A Companion to Museum Studies, edited by Sharon Macdonald, 415-430. Oxford and Malden, MA: Blackwell Publishing, 2006.

Carbonell, Bettina Messias, ed. Museum Studies: An Anthology of Contexts. Chichester: Wiley-Blackwell, 2012.

Chalmers, Steph. 50 Year Mix: A Selection of Works from the University of Waikato Art Collection. Hamilton: University of Waikato, 2014.

Conland, Natasha, ed. The $4^{\text {th }}$ Auckland Triennial: A Last Ride in a Hot Air Balloon. Auckland: Auckland Art Gallery Toi o Tāmaki, 2010.

Corsane, Gerard, ed. Heritage, Museums and Galleries: An Introductory Reader. London and New York: Routledge, 2005.

Daley-Peoples, J. Elam 1890-1990. Auckland: Elam Fine Arts Print Research Unit, 1990.

Dewdney, Andrew, David Dibosa, and Victoria Walsh. Post-Critical Museology: Theory and Practice in the Art Museum. London and New York: Routledge, 2013.

Elam 1950-1983: An Auckland University Centenary Exhibition. Edited by Simon A. Franks. Auckland: Auckland City Art Gallery, 1983. Exhibition catalogue.

Gatley, Julia, ed. Group Architects: Towards a New Zealand Architecture. Auckland: Auckland University Press, 2010.

Glesne, Corrine. The Exemplary Museum: Art and Academia. Edinburgh and Boston, MA: MuseumsEtc, 2013.

Hooper-Greenhill, Eilean. "Changing Values in the Art Museum: Rethinking Communication and Learning." Museum Studies: An Anthology of Contexts, edited by Bettina Messias Carbonell, 517-532. Oxford and Malden, MA: Blackwell Publishing, 2004.

- Museums and the Interpretation of Visual Culture. London and New York: Routledge, 2000. 
Kelly, Melanie. “Introduction.” In Managing University Museums, edited Melanie Kelly, 715. Paris: OECD, 2001.

King, Lyndel, and Janet Marstine. "The University Museum and Gallery: A Site for Institutional Critique and a Focus on the Curriculum." In New Museum Theory and Practice: An Introduction, edited by Janet Marstine, 266-291. Oxford and Malden, MA: Blackwell Publishing, 2006.

Lynn, Victoria. Turbulence: The $3^{\text {rd }}$ Auckland Triennial. Auckland: Auckland Art Gallery Toi o Tāmaki, 2007.

MacDonald, Sharon, ed. A Companion to Museum Studies. Malden, MA: Blackwell Publishing, 2006.

MacDonald, Sharon, and Paul Basu, eds. Exhibition Experiments. Oxford and Malden, MA: Blackwell Publishing 2007.

Mack, Vanessa. "The Dual Role of University Museums: Its Influence on Management." In Managing University Museums, edited by Melanie Kelly, 29-35. Paris: OCED: 2001.

Marshall, Catherine, and Gretchen B. Rossman. Designing Qualitative Research. $5^{\text {th }}$ ed. Thousand Oaks, CA: Sage, 2011.

Marstine, Janet. "Introduction." In New Museum Theory and Practice: An Introduction, edited by Janet Marstine, 1-36. Oxford and Malden, MA: Blackwell Publishing, 2006.

McAloon, William. "Victoria's Art - The Story of a University Collection." In Victoria's Art: A University Collection, edited by William McAloon, 11-23. Wellington: The Adam Art Gallery Te Pātaka Toi, 2005.

McCarthy, Conal. "Grounding Museum Studies: Introducing Practice.” In Museum Practice: The Contemporary Museum at Work, edited by Sharon MacDonald and Helen Rees Leahy, n.p. Oxford and Malden, MA: Wiley Blackwell, 2015.

-, ed. Museum Practice. Volume 4. The International Handbooks of Museum Studies. Oxford and Malden, MA: Wiley Blackwell, 2015.

McClellan, Andrew. "A Brief History of the Art Museum Public." In Art and Its Publics: Museum Studies at the Millennium, edited by Andrew McClellan, 1-49. Oxford and Malden, MA: Blackwell Publishing, 2003.

Patton, Michael Quinn. Qualitative Research and Evaluation Methods. $3^{\text {rd }}$ ed. Thousand Oaks, CA: Sage, 2003. 
Prior, Nick. "Having One's Tate and Eating It: Transformations of the Museum in the Hypermodern Era." In Art and Its Publics: Museum Studies at the Millennium, edited by Andrew McClellan, 51-74. Oxford and Malden, MA: Blackwell Publishing, 2003.

Scott, Carol A. "Museum Measurement: Questions of Value." In Museum Practice: The Contemporary Museum at Work, edited by Sharon MacDonald and Helen Rees Leahy, n.p. Oxford and Malden, MA: Wiley Blackwell, 2015.

Solinger, Janet W., ed. Museums and Universities: New Paths for Continuing Education. New York: Macmillan, 1990.

Vergo, Peter. The New Museology. London: Reaktion Books, 1989.

Warhurst, Alan. "University Museums." In Manual of Curatorship: A Guide to Museum Practice, edited by John M. A. Thompson, 93-99. Oxford: Butterworth-Heineman, 1992.

Weil, Stephen. Making Museums Matter. London and Washington, DC: Smithsonian Institute Press, 2002.

\section{Journal Articles:}

Boylan, Patrick J. "University Museums: Past, Present and Future.” Museum Management and Curatorship 18, no. 1 (1999): 43-56.

Cobley, Joanna. “Art Spaces as Research Stations: Investigating SOFA.” Te Ara: Journal of Museums Aotearoa 29, no. 2 (November, 2004): 22.

Duff, Wendy, Joan M. Cherry, and Rebecka Sheffield. "Creating a Better Understanding of Who We Are: A Survey of Graduate of Museum Studies Program." Museum Management and Curatorship 25, no. 4 (2010): 361-381.

Hammond, Anna, Ian Berry, Sheryl Conkelton, Sharon Corwin, Pamela Franks, Katherine Hart, Wyona Lynch-McWhite, Charles Reeve, and John Stomberg. "The Role of the University Art Museum and Gallery." Art Journal 65, no. 3 (Fall, 2006): 20-39.

Hammond, Gina, Karl van Dyke, and Andrew Simpson, "Adding Value: University and Their Museum.” University Museums and Collections Journal 5, (2012): 7-16.

Jacobs, Carin, Janine Andrews, M. Christine Castle, Nicolette Meister, William Green, Kristen Olson, Andrew Simpson, and Rhianedd Smith. "Beyond the Field Trip: Museum Literacy and Higher Education." Museum Management and Curatorship 24, no. 1 (2009): $5-27$. 
Labrum, Bronwyn, and Conal McCarthy. "Museums and Museum Studies: Bringing Together Theory and Practice." Te Ara Journal of New Zealand: Special Issue - Museum Studies in New Zealand 30, no. 2 (November, 2005): 4-11.

MacDonald, Sally. "Desperately Seeking Sustainability: University Museums in Meaningful Relationships." ICOM University Museums and Collections Study Series 11 (2003): 25-27.

MacLeod, Suzanne. "Making Museum Meanings: Training, Education, Research and Practice." Museum Management and Curatorship 19, no. 1 (2001): 51-61.

MacPherson, Reynold. "An Organised Anarchy or a Community of Diverse Virtue Ethics? The Case of the Elam School of Fine Arts." International Journal of Educational Management 13, no. 5 (1999): 219-226.

Marstine, Janet. "What a Mess! Claiming a Space for Undergraduate Student Experimentation in the University Museum." Museum Management and Curatorship 22, no. 3 (2007): 303-315.

McCarthy, Conal, and Joanna Cobley. "Museums and Museum Studies in New Zealand: A Survey of Historical Developments." Historical Compass 7, no. 2 (2009): 395-413.

O’Brien, Gregory. “Somebody Say Something.” Sport 23 (November, 1999): 9-38.

Spencer, John R. "The University Museum: Accidental Past, Purposeful Future?" Art in America 59, no. 4 (1971): 59-84.

Tirrell, Peter. "Emerging Strengths and Resources of University Museums for Meeting Global Challenges." ICOM University Museums and Collections Study Series 11 (2003): 79 .

Warhurst, Alan. "Triple Crisis in University Museums.” Museum Journal 86, n. 3 (December, 1986): 137-140.

Weber, Cornelia. "The University as a 'Theatre of Knowledge'." ICOM University Museums and Collections Study Series 11 (2003): 19-21.

Were, Graeme. "Re-engaging the University Museum: Knowledge, Collections and Communities at University College London.” Museum Management and Curatorship 25, no. 3 (2010): 291-304. 


\section{Magazine and Newspaper Articles:}

Barton, Chris. “University 'Chainsaw' Moves On.” New Zealand Herald, 22 December, 2008.

Burgess, Malcolm. "Boundaries Blurred at Campus Galleries." New Zealand Herald, 24 November, 2004.

Catherall, Sarah. "Storm Warning for Gallery Opening." Sunday Star Times, 19 September, 1999.

Clifford, Andrew. "Spirited University Collections." Ingenio: The University of Auckland Alumni Magazine (Spring, 2010): 34.

Dunbar, Anna. “Students' Showcase.” The Press, 24 April 2002.

Gardiner, Sue. "Postcards: Auckland.” Art News New Zealand (Autumn, 2006): 21.

Gifkins, Michael. "Keeping Them at Home.” Listener (16-22 August, 1986): 71.

Houlahan, Mike. "Showing a Burgeoning Collection.” Evening Post, 3 November, 1997.

Jones, Simon. “McCahon Treasure for Sale.” Sunday Star Times. 18 April, 1999.

Kennedy, Randy, and Carol Vogel. “Outcry Over a Plan to Sell Museum's Holdings.” The New York Times, 27 January, 2009, http://www.nytimes.com/2009/01/28/arts/design/28rose.html?_r=0 (accessed 9 February, 2015).

Laxon, W. A. "Fraser, George.” Dictionary of New Zealand Biography, Te Ara - the Encyclopedia of New Zealand, http://www.teara.govt.nz/en/biographies/2f20/fraser-george (accessed 9 February, 2015)

Lay, Graeme. "A Fellowship of the Pen.” New Zealand Herald, 6 April, 2013, http://www.nzherald.co.nz/lifestyle/news/article.cfm?c_id=6\&objectid=10875155 (accessed 1 December, 2014).

McNaught, Josie. "Staying put for Art's Sake.” The Dominion, 22 September, 1999.

Moore, Christopher. "Etching for the Future.” The Press, 8 December 2004.

—. "Who Are the Elite?" The Press, 8 December, 2008. 
Orzessek, Eli. "New Art Journal Focuses on Local Knowledge." Te Wahai Nui. 6 April, 2014, http://www.tewahanui.info/index.php/new-art-journal-focuses-on-local-knowledge/ (accessed 9 February, 2015).

Stocker, Mark. "A Cultural Journey: Jonathan Mane-Wheoki in Conversation." Art New Zealand, no. 152 (Summer, 2014-15): 48-56.

\section{Reports:}

Allan, Corey, Arthur Grimes, and Suzi Kerr. "Value and Culture." Motu Work Paper 13-09. Wellington: Motu Economic and Public Policy Research, August, 2013, http://www.mch.govt.nz/files/Value\%20and\%20Culture\%20An\%20Economic\%20Framew ork\%20Aug\%202013\%20pdf\%20(D-0500475).PDF (accessed 28 April 2014).

Goethals, Marion M., and Suzannah Fabing. College and University Art Museum Program. New York: Andrew W. Mellon Foundation, November, 2007, http://mac.mellon.org/CUAM/cuam_report.pdf (accessed 7 April, 2014).

Jackson, Brad. "Centre for New Zealand Research and Discovery Review Report." Gus Fisher Gallery, Centre for Art Studies, the University of Auckland, c. 2006.

Netherlands Museums Association. More Than Worth It: The Social Significance of Museums. Netherlands Museum Association and DSP-groep, April, 2013, http://www.museumvereniging.nl/Portals/0/NMV\%20'More\%20than\%20worth\%20it'.pdf (accessed 28 April 2014).

The Gus Fisher Gallery Exhibitions Committee. "Discussion Draft for the Gus Fisher Gallery." Gus Fisher Gallery, Centre for Art Studies, the University of Auckland, c. 2004.

- "Plan Case Application." Gus Fisher Gallery, Centre for Art Studies, the University of Auckland, 26 November, 2001.

The University of Auckland. The University of Auckland Strategic Plan 2013-2020. Auckland: The University of Auckland, 20 August, 2012, http://www.auckland.ac.nz/en/about/the-university/official-publications/strategic-plan.html (accessed 25 August, 2014).

University Museums Group, University Museums in Scotland, and Liz Hide. Impact and Engagement: University Museums for the $21^{\text {st }}$ Century, 2013. 


\section{Conference Papers:}

Arnold-Forster, Kate. "Museums for the Future: Recognising New Relevance of University Museums." Paper presented at New Roads for University Museums, $6{ }^{\text {th }}$ International Congress for University Museums, Mexico City Mexico, 2006.

Burman, Lars. "University Museums as Strategic Tool: On Communicating University Values." Paper presented at Awareness and Action - University Museums Tody, Uppsala, Sweden, 25 September - 1 October, 2005.

Bywaters, Malcolm. "The Role of the Regional University Gallery, Case Study: The Academy Gallery, Launceston." Paper presented at the Conference on the Future of University Museums and Art Galleries in the New Century, Launceston, Tasmania, Australia, May, 2005.

De Maret, Pierre. "Exposing the Ivory Tower." Paper presented at Awareness and Action University Museums Today, Uppsala, Sweden, 25 September - 1 October, 2005.

Jonaitis, Aldona. "Joining the $21^{\text {st }}$ Century While Remaining Honest to Our Mission as University Museums." Paper presented at New Roads for University Museums, $6^{\text {th }}$ International Congress for University Museums, Mexico City, Mexico, 2006.

King, Lyndel. "Engaging University Students." Paper presented at Intensifying Support for and Increasing Audiences in University Museums and Collections." Proceedings of the First Conference of the International Committee of ICOM for the University Museums and Collections, Barcelona, Spain, 2-4 June, 2001.

MacDonald, Sally. "Research on Show: The University Museum as Public Laboratory." Paper presented at New Roads for University Museums, $6^{\text {th }}$ International Congress for University Museums, Mexico City, Mexico, 2006.

Marstine, Janet. "The Transformative Exhibition, the Museum Intervention, and the Transformative Pedagogy; New Museum Theory: What Students Need." Paper presented at The College Museum: A Collision of Disciplines, A Laboratory of Perception Conference, Francis Young Tang Teaching Museum and Art Gallery, Skidmore College, Saratoga Springs, New York, 7-8 April, 2006.

McCarthy, Conal. "The Politics of Display: Exhibiting in a Town/Gown Gallery." Paper presented at A Conference on the Future of University Museums and Art Galleries in the New Century, Launceston, Tasmania, Australia, May, 2005. 
McIntyre, Sophie. "Thinking Outside the Square: Orientating Aotearoa." Paper presented at A Conference on the Future of University Museums and Art Galleries in the New Century, Launceston, Tasmania, Australia, May, 2005.

Simpson, Andrew. "Integrating University Museums Into Museum Studies Programs." Paper presented at Awareness and Action - University Museums Today, Uppsala, Sweden, 25 September-1 October, 2005.

Snell, Ted. "Valuing University Art Galleries." Paper presented at the Conference on the Future of University Museums and Art Galleries in the New Century, Launceston, Tasmania, Australia, May, 2005.

Stanbury, Peter. “A Panoramic View of University Museums.” Paper presented at Intensifying Support for and Increasing Audiences in University Museums and Collections, Proceedings of the First Conference of the International Committee of ICOM for the University Museums and Collections, Barcelona, Spain, 2-4 June, 2001.

- " "Adding Value to University Collections." Paper presented at Exposing and Exploiting the Distinct Character of University Museums and Collections, Proceedings of the Second Conference of the International Committee of ICOM for the University Museums and Collections, Sydney and Canberra, Australia, September-October, 2002.

Wallace, Sue-Anne. "Challenges Facing University Museums." Paper presented at Intensifying Support for and Increasing Audiences in University Museums and Collections, Proceedings of the First Conference of the International Committee of ICOM for the University Museums and Collections, Barcelona, Spain, 2-4 June, 2001.

- "University Museums at the Crossroads." Paper presented at Exposing and Exploiting the Distinct Character of University Museums and Collections, Proceedings of the Second Conference of the International Committee of ICOM for the University Museums and Collections, Sydney and Canberra, Australia, September-October, 2002.

Weinberg, Adam, and Fred Wilson. “College Museums: A Visual Laboratory?” Dialogue presented at The College Museum: A Collision of Disciplines, A Laboratory of Perception Conference, Frances Young Tang Teaching Museum and Art Gallery, Skidmore College, Saratoga Springs, New York, 7-8 April, 2006.

\section{Television Episodes:}

Frontseat. Episode no. 28, first broadcast in 2004 by TVNZ. Produced by Gemma Gracewood. 


\section{Websites:}

Argos Aotearoa. http://www.argosaotearoa.org.nz (accessed 9 February, 2015).

Bradley, Laurel. "Curricular Connections: The College/University Art Museum as Site for Teaching and Learning." CAA Reviews, http://www.caareviews.org/reviews/1309 (accessed 1 May, 2014).

Casting Room Gallery. "About.” http://thecastingroom.blogspot.co.nz (accessed 11 July, 2014).

Canadian Art Museum Directors Organisation, Organisation de Directeurs des Musées de'Art du Canada. "What is an Art Museum?" http://camdo.ca/blog?page_id=458 (accessed 26 January, 2015).

Christchurch Polytechnic Institute of Technology. "About ArtBox." http://www.cpit.ac.nz/industry-and-research/industry-and-partnerships/capabilities-andtechnologies-for-industry/artbox/artbox (accessed 2 February, 2015).

College of Creative Arts Toi Rauwharangi. "New International Residency has Contemporary Focus.” Massey University, 29 July, 2014.

http://creative.massey.ac.nz/about/news/2014/july/new-international-arts-residency-hascontemporary-focus/ (accessed 24 November, 2014).

Galbraith, Heather. "Whiti o Rehua - the School of Art." Massey University. http://creative.massey.ac.nz/about/school-of-art (accessed 24 November, 2014).

Heritage New Zealand Pouhere Taonga. "Television New Zealand Studios." http://www.heritage.org.nz/the-list/details/660 (accessed 29 December, 2014).

Ilam School of Fine Arts. "About SoFA.” The University of Canterbury. http://www.sofa.canterbury.ac.nz/about.hml (accessed 11 July, 2014).

—. "Exhibitions." The University of Canterbury. http://www.sofa.canterbury.ac.nz (accessed, 11 July, 2014).

Lau, Carm. "You're Allowed to Write on Walls if You're an Adult." Writing Cradle (blog), 26 March, 2014, http:/writingcradle.wordpress.com/2014/03/26/youre-allowed-to-write-onwalls-if-youre-an-adult/ (accessed 3 December, 2014).

Pollick, Kerryn. "Tertiary Education.” Te Ara - The Encyclopedia of New Zealand. 19 December, 2012, http://www.teara.govt.nz/en/tertiary-education (accessed 27 August, 2014). 
Ramp Gallery. http://www.rampgallery.co.nz (accessed 9 February, 2014).

Rodini, Elizabeth. "The Ivory Tower and the Crystal Palace: Universities, Museums, and the Potential of Public Art History." CAA Reviews. http://www.caareviews.org/reviews/1055 (accessed 1 May, 2014).

Sexual Politics Now. “The Project.” http://www.sexualpoliticsnow.org.nz/about/the-project/ (accessed 12 January, 2015).

St Paul St Gallery. "About Us.” Auckland University of Technology. http://www.stpaulst.aut.ac.nz/gallery-information/about-the-gallery (accessed 27 June, 2014).

Te Pōkai Tara Universities New Zealand. "The NZ University System." http://www.universitiesnz.ac.nz/nz-university-system (accessed 31 August, 2014).

—. "Story of New Zealand Universities." http://www.universitiesnz.ac.nz/why-universitiesmatter/story (accessed 31 August, 2014).

Tertiary Education Commission. "Performance-Based Research Fund." http://www.tec.govt.nz/Funding/Funding-finder/Performance-Based-Research-Fund-PBRF/ (accessed 30 December, 2014)

The $5^{\text {th }}$ Auckland Triennial. "Yangjiang Group." http://aucklandtriennial.com/artists/yangjiang-group (accessed 8 December, 2014).

The Adam Art Gallery. “About.” http://www.adamartgallery.org.nz/about-exhibitions/visionand-mission-statement (accessed 22 June, 2014).

—. "Current Research.” http://www.adamartgallery.org.nz/research/current (accessed 3 July, 2014).

—. "Research - About." http://www.adamartgallery.org.nz/research/about (accessed 3 July, 2014).

—. "Services." http://www.adamartgallery.org.nz/about-exhibitions/services (Accessed 3 July, 2014)

—. "Staff and Advisory Board." http://www.adamartgallery.org.nz/about-exhibition/staffboard (accessed 3 July, 2014)

The Auckland Festival of Photography, "Anxious Production: Disrupting a Functionary Bond." 
http://www.photographyfestival.org.nz/programme/detail.cfm?exhibition_id=1736\&exhibiti on_date $=2013-06-1$ (accessed 8 December, 2014).

\section{—. "Bronek Kozka - Auschwitz Revisited."}

http://www.photographyfestival.org.nz/programme/detail.cfm?exhibition_id=1849\&exhibiti on_date $=1 \% 20$ june $\% 202014$ (Accessed 8 December, 2014)

The Fitzwilliam Museum. "History of the Fitzwilliam Museum."

http://www.fitzmuseum.cam.ac.uk/about/museumhistory.html (accessed 31 August, 2014).

The National Institute of Creative Arts and Industries. " $5^{\text {th }}$ Auckland Triennial." The University of Auckland. http://www.creative.auckland.ac.nz/en/about/events/events2013/2013/05/10/5 ${ }^{\text {th }}$-Auckland-Triennial.html (accessed 15 June, 2014).

—. "A Different View: Artists Address Pornography." The University of Auckland. http://www.creative.auckland.ac.nz/en/about/events/events-2013/A-Different-View-Artistaddress-pornography.html (accessed 15 June, 2014).

—. "About Elam." The University of Auckland.

http://www.creative.auckland.ac.nz/en/about/our-faculty/schools-programmes-andcentres/fine-arts/about-elam.html (accessed 2 December, 2014).

—. "All Your Base are Belong to Us." The University of Auckland. http://www.creative.auckland.ac.nz/en/about/events/events-2009/2009/08/18/All-YourBase-Are-Belong-To-Us.html (accessed 31 October, 2014).

—. "Argos Aotearoa." The University of Auckland. http://www.creative.auckland.ac.nz/en/about/events/events-2014-1/2014/03/argosaotearoa.html (accessed 28 October, 2014)

—. "Art of the Invisible: Exploring the World of Nanotechnology." The University of Auckland. http://www.creative.auckland.ac.nz/en/about/events/events2013/2013/02/08/Art-of-the-invisible-Exploring-the-world-of-Nanotechnology.html (accessed 12 June, 2014).

—. "Auschwitz Revisited: By Bronek Kozka.” The University of Auckland. http://www.creative.auckland.ac.nz/en/about/events/events-20141/2014/06/auschwitz_revisited_by_bronek_kozka.html (accessed 17 August, 2014).

—. "Collateral: Printmaking as Social Commentary." The University of Auckland. http://www.creative.auckland.ac.nz/en/about/events/events-2011/2011/07/01/CollateralPrintmaking-as-social-commentary.html (accessed 19 June, 2014). 
- "Design Shanghai /Aesthetics City." The University of Auckland. http://www.creative.auckland.ac.nz/en/about/events/events-2014-1/2014/04/designshanghai-aesthetics-city.html (accessed 28 October, 2014).

—. "Elam Art Fair." The University of Auckland. http:/www.creative.auckland.ac.nz/en/about/events/events-2013/2013/12/06/Elam-ArtFair.html (accessed 28 October, 2014).

—. "Elam Graduate Show." The University of Auckland. http://www.creative.auckland.ac.nz/en/about/events/events-2011/2011/11/26/ElamGraduate-Show.html (accessed 30 October, 2014).

—. "Elam Graduate Show." The University of Auckland. http://www.creative.auckland.ac.nz/en/about/events/events-2012-1/2012/11/24/ElamGraduate-Show.html (accessed 30 October, 2014).

—. "George Fraser Gallery." The University of Auckland. http://www.creative.auckland.ac.nz/en/about/galleries-and-collections/george-frasergallery.html (accessed 17 August, 2014).

—. "Gifted." The University of Auckland. http://www.creative.auckland.ac.nz/en/about/events/events-2014-1/2014/09/gifted.html (accessed 3 November, 2014).

- "Group Architects: Towards a New Zealand Architecture." The University of Auckland. http://www.creative.auckland.ac.nz/en/about/events/events-2010/10/15/Group-ArchitectsTowards-a-New-Zealand-Architecture.html (accessed 3 November, 2014).

—. "Gus Fisher Gallery." The University of Auckland. http://www.creative.auckland.ac.nz/en/about/galleries-and-collections/gus-fishergallery.html (accessed 12 June, 2014).

- . "Hutton and Cotton: The McGregor Museum Revisited." The University of Auckland. http://www.creative.auckland.ac.nz/en/about/events/events-2012-1/2012/01/20/Hutton-andCotton-The-McGregor-Museum-Revisited.html (accessed 12 June, 2014).

—. "Last Ride in a Hot Air Balloon." The University of Auckland. http://www.creative.auckland.ac.nz/en/about/events/events-2010/2010/03/12/Last-Ride-ina-Hot-Air-Balloon.html (accessed 31 October, 2014).

—. "Let's Talks Art (For Elam Students)." The University of Auckland. http://www.creative.auckland.ac.nz/en/about/notices/notices-2012-3/2012/01/12/Let-s-TalkArt-for-Elam-students.html (accessed 7 December, 2014). 
—. "Line: Breadthless Length." The University of Auckland.

http://www.creative.auckland.ac.nz/en/about/events/events-2012-1/2012/05/31/Line-

Breadthless-Length.html (accessed 30 October, 2014).

—. "New Graduate Works." The University of Auckland.

http://www.creative.auckland.ac.nz/en/about/events/events-2013/2013/12/06/New-

Graduate-Works.html (accessed 12 June, 2014).

—. "New Graduate Works." The University of Auckland.

http://www.creative.auckland.ac.nz/about/events/events-2014/2014/December/newgraduate-works.html (accessed 3 November, 2014).

—. "Nuala Gregory: Exploded View." The University of Auckland.

http://www.creative.auckland.ac.nz/en/about/events/events-2010/2010/06/04/Nuala-

Gregory-Exploded-View.html (accessed 3 November, 2014).

—. "Our Faculty." The University of Auckland.

http://www.creative.auckland.ac.nz/about/our-faculty.html. (accessed 12 June, 2014).

—. "So Where's Home?" The University of Auckland.

http://www.creative.auckland.ac.nz/en/about/events-2014-1/2014/08/so-wheres-home.html (accessed 17 August, 2014).

—. "The Conch is Calling." The University of Auckland.

http://www.creative.auckland.ac.nz/en/about/events/events-2008/2008/10/30/The-Conch-isCalling.html (accessed 31 October, 2014).

—. "The Power of Portraiture: Curated by Erin Griffey." The University of Auckland. http://www.creative.auckland.ac.nz/en/about/events/events-2008/2008/11/28/The-Power-ofPortraiture-curated-by-Erin-Griffey.html (accessed 12 June, 2014).

—. "The New Neophytes." The University of Auckland.

http://www.creative.auckland.ac.nz/en/about/events/events-2009/2009/03/04/The-New-

Neophytes.html (accessed 31 October, 2014).

—. "The University of Auckland Art Collection." The University of Auckland.

http://www.creative.auckland.ac.nz/en/about/galleries-and-collections/university-artcollection.html (accessed 12 June, 2014).

-. "This Much is Certain - Elam Grad Show." The University of Auckland.

http://www.creative.auckland.ac.nz/en/about/events/events-2008/2008/05/07/This-much-iscertain-Elam-Grad-Show.html (accessed 30 August, 2014). 
—. "Tuākana Programme.” The University of Auckland.

http://www.creative.auckland.ac.nz/en/for/maori-and-pacific-students/tuakanaprogramme.html (accessed 7 December, 2014).

—. "Under Construction: Open Studio Practice by $4^{\text {th }}$ Year Elam Students." The University of Auckland. http://www.creative.auckland.ac.nz/en/about/events/events2008/2008/04/16/Under-Construction-open-studio-practice-by- $4^{\text {th }}$-year-Elam-students.html (accessed 31 October, 2014).

—. "Whakaahua|Portrait." The University of Auckland. http://www.creative.auckland.ac.nz/en/about/events/events-2014-1/2014/08/whakaahua--portrait-.html (accessed 17 August, 2014).

—. "Yangjiang Group, Shi Tu Tong Gui." The University of Auckland. http://www.creative.auckland.ac.nz/en/about/events/events-2013/2012/05/11/YangjanGroup-Shu-Tu-Tong_Gui.html (accessed 28 October, 2014).

The University of Auckland. "Elam Students Win Award at International Design Exhibition." http://www.auckland.ac.nz/en/about/news-events-and-notices/new/news2013/2013/12/18/elam-students-win-award-at-international-design-exhibition.html (accessed 28 October, 2014).

—. "The University of Auckland Charter 2003." https://www.auckland.ac.nz/en/for/currentstudents/cs-academic-information/cs-regulations-policies-and-guidelines/cs-universitycharter.html (accessed 17 November, 2014).

Wallace Arts Trust. "The Wallace Arts Trust Loan Programme." http://www.wallaceartstrust.org.nz/the-wallace-arts-trust-loan-programme (accessed 27 June, 2014).

Window. "About." The University of Auckland. http://www.window.auckland.ac.nz/about.html (accessed 2 November, 2014).

\section{Interviews and Correspondence:}

Auckland University Honours Student. Interviewed by author. Tape recording. 24 September 2014. Auckland.

Auckland University Postgraduate Fine Arts Student. Interviewed by author. Tape recording. 26 September 2014. Auckland.

Auckland University Staff Member. E-mail correspondence with author. 16 October 2014. 
Auckland University Staff Member. Interviewed by author. Tape recording. 25 September 2014. Auckland.

Auckland University Undergraduate Fine Arts Student. E-mail correspondence with author. 29 September 2014.

Barton, Christina. Interviewed by author. Tape recording. 4 August 2014. Wellington.

Chalmers, Stephanie. E-mail correspondence with author. 22 July 2014.

Galbraith, Heather. E-mail correspondence with author. 6 July 2014.

Stockman-Young, Jaimee. E-mail correspondence with author. 1 August 2014.

—. Interviewed by author. Tape recording. 26 September 2014. Auckland.

Neate, Robin. E-mail correspondence with author. 22 July 2014.

Tyler, Linda. E-mail correspondence with author. 19 July 2014.

—. E-mail correspondence with author. 15 December 2014.

-. Interview by author. Tape recording. 31 August 2014. Wellington. 


\title{
Appendices
}

\section{Appendix A: Questionnaire Letter}

\author{
Penny Baines \\ c/- Museum and Heritage Studies \\ School of Art History, Classics, and Religious Studies \\ Victoria University of Wellington \\ PO Box 600 \\ Wellington 6140
}

27 June 2014

Dear...,

My name is Penny Baines and I am a Masters student in the Museum and Heritage Studies programme at Victoria University. I am currently undertaking a thesis project which examines how and why New Zealand university art galleries do or do not integrate themselves into their university communities.

At this stage, I am gathering general information about New Zealand university art galleries through an open-ended questionnaire and will later undertake two detailed case studies. I am sending you this e-mail to ask whether or not you would like to participate in this research by completing my questionnaire about your art gallery and its role and purpose within the university community. The questionnaire consists of only five questions which you may answer as thoroughly or as generally as you wish. I understand that you have an incredibly busy schedule and I would greatly appreciate your time in assisting me with my research. If you are unable to answer the questionnaire due to time or unavailability, it would be greatly appreciated if another staff member of the art gallery could complete it. If you consent, could you please email me before Monday 7 July and I will email or post the questionnaire to you.

If you have any further questions or would like to receive further information about the project, please contact me at penny.baines@vuw.ac.nz or phone ...; or my supervisor, Associate Professor Dr Conal McCarthy at Victoria University conal.mccarthy@vuw.ac.nz or 044637470 .

Kind regards,

Penny Baines 


\section{Appendix B: Questionnaire}

\section{New Zealand University Art Galleries Questionnaire}

In the United Kingdom and the United States, university art galleries have been described as "forums," "laboratories" and "portals" for the presentation of diverse and interdisciplinary ideas. What metaphor or short phrase would you use to describe your university art gallery?

What do you think is the role and purpose of a university art gallery?

What do you consider to be the main advantages and challenges that university art galleries face?

Do you think it is important for university art galleries to align themselves with the academic mission of their parent organization? Why or why not? If so, could you provide an example of how your university art has done this?

To what extent, if any, are university students and faculty involved in your university art gallery and what role do they play? 


\section{Appendix C: Ethics Approval}

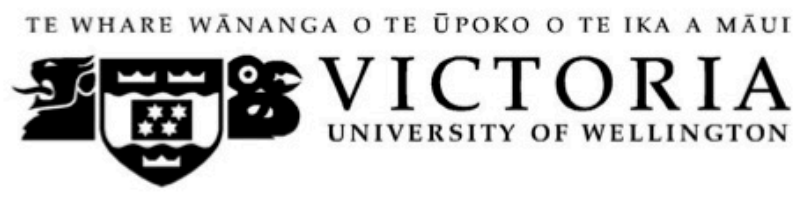

MEMORANDUM

Phone $\quad 0-4-4635676$

Fax $\quad 0-4-4635209$

Email_Allison.kirkman@vuw.ac.nz

\begin{tabular}{l|l}
\hline TO & Penny Baines \\
\hline COPY TO & Conal McCarthy \\
\hline FROM & Dr Allison Kirkman, Convener, Human Ethics Committee \\
\hline
\end{tabular}

\begin{tabular}{l|l}
\hline DATE & 18 July 2014 \\
\hline PAGES & 1 \\
\hline
\end{tabular}

\begin{tabular}{l|l} 
SUBJECT & $\begin{array}{l}\text { Ethics Approval: } \mathbf{2 1 1 6 5} \\
\text { New Zealand University Art Galleries }\end{array}$ \\
\hline
\end{tabular}

Thank you for your application for ethical approval, which has now been considered by the Standing Committee of the Human Ethics Committee.

Your application has been approved from the above date and this approval continues until 22 February 2015. If your data collection is not completed by this date you should apply to the Human Ethics Committee for an extension to this approval.

Best wishes with the research.

Allison Kirkman

Human Ethics Committee

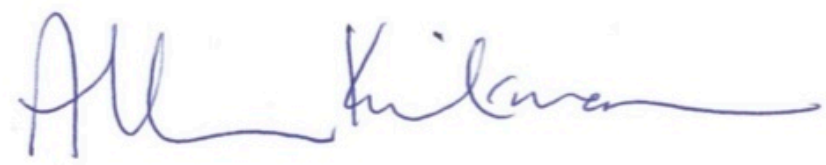




\title{
Appendix D: Participant Information Sheets
}

\section{"New Zealand university art galleries": Information sheet for university art gallery directors}

\author{
Researcher: Penelope (Penny) Baines, Museum and Heritage Studies, School of Art \\ History, Classics, and Religious Studies, Victoria University of Wellington
}

I am a Masters student in the Museum and Heritage Studies programme at Victoria University of Wellington. As part of this degree I am undertaking a research project leading to a thesis. The project I am undertaking is examining how and why New Zealand university art galleries do or do not integrate themselves into their university communities. This research project has received approval from the Victoria University of Wellington Human Ethics Committee.

In order to investigate this problem, I am undertaking case studies in relation to two New Zealand university art galleries. My research began by sending out an open-ended questionnaire to the seven university art galleries in New Zealand. From the responses I received, I selected two case studies for further investigation. The selected galleries were approached to see whether they would like to participate further in the study. For those that gave their consent I will now undertake interviews with: the directors of each gallery, a university faculty member who uses the art gallery in an academic course, a faculty member who does not use the art gallery in an academic course, and a university academic managerial staff member, as well as a focus group of 4 to 6 students from each university. The interviews will be conducted at a time and location which is most convenient for the participant. Interviews are expected to take approximately one hour with the possibility of a follow-up interview if necessary (and if the participant agrees). I intend to record these interviews and take written notes. A schedule of the main questions will be emailed or posted to the research participant a week in advance of the interview. Participants will also have the opportunity to verify a full transcript of the interview data.

It is important to be aware that the identity of the institution and art gallery director will be recognisable in the research results. Should the participants feel the need to withdraw from the study they may do so without question or any penalty to themselves or their institutions before 31 October 2014, by contacting the researcher at the contact details below.

No other person besides the researcher and research supervisor will have access to the interview data during the course of the research. At the completion of the project, all research materials will be destroyed.

If you have any questions or would like to receive further information about the project, please contact me at penny.baines@vuw.ac.nz or phone ... or my supervisor, Associate Professor Dr Conal McCarthy at Victoria University conal.mccarthy@vuw.ac.nz or 04463 7470 .

Kind regards, Penny Baines 


\title{
"New Zealand university art galleries": Information sheet for university staff members
}

\author{
Researcher: Penelope (Penny) Mary Baines, Museum and Heritage Studies, School of Art \\ History, Classics, and Religious Studies, Victoria University of Wellington
}

I am a Masters student in the Museum and Heritage Studies programme at Victoria University of Wellington. As part of this degree I am undertaking a research project leading to a thesis. The project I am undertaking is examining how and why New Zealand university art galleries do or do not integrate themselves into their university communities. The research project has received approval from the Victoria University of Wellington Human Ethics Committee.

In order to investigate this problem, I am undertaking case studies in relation to two New Zealand university art galleries. My research began by sending out an open-ended questionnaire to the seven university art galleries in New Zealand. From the responses I received, I selected two case studies for further investigation. The selected galleries were approached to see whether they would like to participate further in the study. For those that gave their consent I will now undertake interviews with the directors of each gallery, a university faculty member who uses the art gallery in an academic course, a faculty member who does not use the art gallery in an academic course, and a university academic managerial staff member, as well as a focus group of 4 to 6 students from each university. The interviews will be conducted at a time and location which is most convenient for the participant. Interviews are expected to take approximately half an hour, with the possibility of a followup interview if necessary (and if the participant agrees). I intend to record these interviews and take written notes. A schedule of the main questions will be emailed or posted to the research participant a week in advance of the interview. Participants will also have the opportunity to verify a full transcript of the interview data.

It is important to be aware that the identity of the institution will be recognisable in the research results, however the identity of all university faculty members and students will remain confidential. Should the participant feel the need to withdraw from the study they may do so without question or any penalty to themselves or their institution before 31 October 2014, by contacting the researcher at the contact details below.

No other person besides the researcher and the research supervisor will have access to the interview data during the course of the research. At the completion of the research, all research materials will be destroyed.

If you have any questions or would like to receive further information about the project, please contact me at penny.baines@vuw.ac.nz or phone ... or my supervisor, Associate Professor Dr Conal McCarthy at Victoria University conal.mccarthy@vuw.ac.nz or 04463 7470.

Kind regards, Penny Baines 


\title{
"New Zealand university art galleries": Information sheet for university students
}

\author{
Researcher: Penelope (Penny) Baines, Museum and Heritage Studies, School of History, \\ Classics, and Religious Studies, Victoria University of Wellington
}

I am a Masters student in the Museum and Heritage Studies programme at Victoria University of Wellington. As part of this degree I am undertaking a research project leading to a thesis. The project I am undertaking is examining how and why New Zealand university art galleries do or do not integrate themselves into their university communities. This research project has received approval from the Victoria University of Wellington Human Ethics Committee.

In order to investigate this problem, I am undertaking case studies in relation to two New Zealand university art galleries. My research began by sending out an open-ended questionnaire to the seven university art galleries in New Zealand. From the responses I received, I selected two case studies for further investigation. The selected galleries were approached to see whether they would like to participate further in the study. For those that gave their consent I will now undertake interviews with: the directors of each gallery, a number of faculty members who do and do not utilise the art gallery in academic courses, a university academic managerial staff member, as well as several university students. The interviews will be conducted at a time and location that is most convenient for the participants. Interviews are expected to take approximately half an hour with the possibility of a follow-up interview if necessary (and if the participant agrees). I intend to record these interviews and take written notes. A schedule of the main questions will be emailed or posted to the research participant a week in advance of the interview. Participants will also have the opportunity to verify a full transcript of the interview data.

It is important to be aware that although the interviews will be recorded, the responses and identities of the university student participants will remain anonymous. Should the participants feel the need to withdraw from the study they may do so without question or any penalty to themselves or their institutions before 31 October 2014, by contacting the researcher at the contact details below.

No other person besides the researcher and research supervisor will have access to the interview data during the course of the research. At the completion of the project, all research materials will be destroyed.

If you have any questions or would like to receive further information about the project, please contact me at penny.baines@vuw.ac.nz or phone ... or my supervisor, Associate Professor Dr Conal McCarthy at Victoria University conal.mccarthy@vuw.ac.nz or 04463 7470 .

Kind regards, Penny Baines 


\title{
Appendix E: Participant Consent Forms
}

\section{"New Zealand university art galleries": Participant consent form for university art gallery directors}

\author{
Researcher: Penelope (Penny) Mary Baines, Museum and Heritage Studies, School of \\ Art History, Classics and Religious Studies, Victoria University of Wellington
}

I have been given and have understood an explanation of this research. I have had an opportunity to ask questions and have them answered to my satisfaction. I understand that I may withdraw myself (or any information I have provided) from this project before 31 October 2014 without having to give reason or without penalty of any sort.

Please tick the boxes to show your understanding and agreement of the following:

I have been provided with adequate information relating to the nature and objectives of this research project. I have understood the information and have been given an opportunity to seek further clarification or explanations.

I understand that I may withdraw from this study at any time before 31 October. Any data that may have been provided before this time will not be used in the research.

I understand that my identity as well as the identity or the institution will be recognisable in the research.

I consent to information or opinions which I have been given being attributed to me in any reports on this research

I consent to having this interview recorded.

I understand that I will have the opportunity to check a full transcript of the interview data before it is used for analysis.

I understand that when this research is completed the interview recordings and/or email transcripts will be destroyed.

I agree to take part in this research.

Signed: 


\section{"New Zealand university art galleries": Participation consent form for university staff members}

\section{Researcher: Penelope (Penny) Mary Baines, Museum and Heritage Studies, School of Art History, Classics and Religious Studies, Victoria University of Wellington}

I have been given and have understood an explanation of this research. I have had an opportunity to ask questions and have them answered to my satisfaction. I understand that I may withdraw myself (or any information I have provided) from this project before 31 October 2014 without having to give reason or without penalty of any sort.

Please tick the boxes to show your understanding and agreement of the following:

I have been provided with adequate information relating to the nature and objectives of this research project. I have understood the information and have been given an opportunity to seek further clarification or explanations.

I understand that I may withdraw from this study at any time before 31 October. Any data that may have been provided before this time will not be used in the research.

$\square$ I understand that the identity of all participants who are university staff members will remain confidential, however the identity of the institution will be recognisable in the research.

I consent to having this interview recorded.

I understand that I will have the opportunity to check a full transcript of the interview data before it is used for analysis.

I understand that when this research is completed the interview recordings and/or email transcripts will be destroyed.

I agree to take part in this research.

Signed: 


\title{
"New Zealand university art galleries": Participation consent form for university students
}

\author{
Researcher: Penelope (Penny) Mary Baines, Museum and Heritage Studies, School of \\ Art History, Classics and Religious Studies, Victoria University of Wellington
}

I have been given and have understood an explanation of this research. I have had an opportunity to ask questions and have them answered to my satisfaction. I understand that I may withdraw myself (or any information I have provided) from this project before 31 October 2014 without having to give reason or without penalty of any sort.

Please tick the boxes to show your understanding and agreement of the following:

I have been provided with adequate information relating to the nature and objectives of this research project. I have understood the information and have been given an opportunity to seek further clarification or explanations.

I understand that I may withdraw from this study at any time before 31 October. Any data that may have been provided before this time will not be used in the research.

$\square$ I understand that the identity of all participants who are university students will remain confidential, however the identity of the institution will be recognisable in the research.

I consent to having this interview recorded.

I understand that I will have the opportunity to check a full transcript of the interview data before it is used for analysis.

I understand that when this research is completed the interview recordings and/or email transcripts will be destroyed.

I agree to take part in this research.

Signed:

Name of participant (please print clearly):

Date: 


\section{Appendix F: Participant Interview Questions}

\section{Interview questions for Gallery directors:}

1. According to your knowledge, what was the impetus behind the establishment of the Gallery?

2. Could you explain the governance structure of the Gallery (i.e. board of trustees, advisory board, etc.)?

3. The Gallery is part of the National Institute of Creative Arts and Industries, could you explain what this faculty is, and how the Gallery fits within it?

4. Most art galleries and museums are required to attain specific key performance indicators. Is the Gallery required to do this? If so, what are these KPIs and who develops them?

5. Does the Gallery have a mission statement, statement of intent, or an overarching goal/objective? If so, how was it developed and how has it changed? In what ways has the Gallery achieved its goals? What are the challenges the Gallery faces in striving to achieves it goals/objectives?

6. Does the strategic plan of the University of Auckland affect the goals/objectives of Gallery? In what ways, if any, does the Gallery align itself with the strategic mission of its parent organisation?

7. Do you think it is important for a university art gallery to align itself with the academic mission of its parent organisation? If so, in what ways is the Gallery used by the University of Auckland as a teaching tool and resource?

8. The New Zealand Education Act (1989) states that a university's role is to be a 'critic and conscience of society' and 'to question and test received wisdom, to put forwarded new ideas and state controversial or unpopular opinions'. Do you believe that the institution of a university art gallery can assist in the fulfilment of this role? If so, in what ways? In what specific ways does the Gallery do so?

9. Some scholars argue that museum literacy (i.e. the skills needed to read an installation or exhibition, take apart its narrative structure, interpret its voice, and probe its critical objectives) should be taught as part of all undergraduate degrees so that students can become informed consumers of culture. Do you agree with this statement? Why/why not? In what ways does the Gallery provide students with the opportunity and ability to gain skills in museum literacy? 
10. In 2000, museum theorist, Eilean Hooper-Greenhill, postulated the idea of the postmuseum in reference to a new and reinvented museum-like establishment. A postmuseum can be described as an institution that clearly articulates its agenda, strategies, and decision-making processes and continually re-evaluates them in a way that acknowledges the politics of representation. It shares power with the communities it serves, including source communities. The post-museum listens and responds sensitively as it encourages diverse groups to become active participants in museum discourse. It does not shy away from difficult issues, but exposes conflict and contradiction. In what ways do you think university art galleries in general, and the Gallery specifically, provide a model for the emerging post-museum?

\section{Interview questions for University staff members:}

1. As a University staff member, what do you think of the University's art galleries being aligned with the National Institute of Creative Arts and Industries?

2. Have you ever used the university art gallery in your classes? If so, in what ways did you utilise the art gallery? In your opinion, what are the barriers faculty members encounter when attempting to integrate the art gallery into their teaching and classes?

If the art gallery has been used in classes:

What are the benefits and challenges of utilising the art gallery in your teaching? That is, how does it affect student learning? In what ways does it differ to teaching in a classroom environment?

3. In what ways, if any, have you utilised the art gallery in your own academic research?

4. Some scholars argue that museum literacy (i.e. the skills needed to read an installation or exhibition, take apart its narrative structure, interpret its voice, and probe its critical objectives) should be part of general undergraduate education. What are your thoughts on this statement? Do you believe university art galleries have the potential to teach students these skills? Why or why not?

5. In 2009, Brandeis University in Massachusetts caused widespread controversy over its decision to close its campus art museum and sell it entire collection in order to ease the University's financial burdens. During times of financial crisis, university art galleries are often deemed to be superfluous to the university. Why do you think this is?

6. In 2000, museum theorist Eilean Hooper-Greenhill, postulated the idea of the postmuseum in reference to a new and reinvented museum-like establishment. A postmuseum can be described as an institution that clearly articulates its agenda, strategies, and decision-making processes and continually re-evaluates them in a way that acknowledges the politics of representation. It shares power with the communities it serves, including source communities. The post-museum listens and responds sensitively 
as it encourages diverse groups to become active participants in museum discourse. It does not shy away from difficult issues, but exposes conflict and contradiction. Do you believe university art galleries have the potential to provide a model for the postmuseum? Do you think that the Auckland University art galleries could be thought of post-museums?

\section{Interview questions for University students:}

1. Could you please describe your experiences with the university art galleries at the University of Auckland? How have you utilised these art galleries in the past (i.e. for leisure, for class, for socialising with friends/family, for research, etc.)?

2. Has any academic course/project you've taken utilised the art galleries in any way? If so, what course/project was it and how were the art galleries used?

3. What sort of exhibitions and public programmes would you like to see at the university art galleries?

4. To your knowledge, what opportunities, if any, do the university art galleries provide in order to encourage student participation and involvement?

5. In your opinion, what does an art gallery contribute to a university? What do you think the role and purpose of a university art gallery should be?

6. In general, how do you think students view the university's art galleries?

7. The New Zealand Education Act (1989) states that a university's role is to be 'a critic and conscience of society' and 'to question and test received wisdom, to put forward new ideas and state controversial or unpopular opinions.' Do you believe that the institution of the university art gallery can assist in the fulfilment of this role? Do any specific examples of Auckland University art galleries acting as a 'critic and conscience of society' come to mind? 